\title{
Bioaccumulation and Toxicokinetics of Brominated and Chlorinated Contaminants in East Greenland Polar Bears (Ursus maritimus)
}

\author{
by
}

\author{
Wouter A. Gebbink
}

\begin{abstract}
A Thesis Submitted to the Faculty of Graduate Studies and Research in Partial Fulfilment of the Requirements for the Degree of Master of Science at Carleton University
\end{abstract}

(C) Wouter A. Gebbink 2006 


$\begin{array}{ll}\begin{array}{l}\text { Library and } \\ \text { Archives Canada }\end{array} & \begin{array}{l}\text { Bibliothèque et } \\ \text { Archives Canada }\end{array} \\ \begin{array}{l}\text { Published Heritage } \\ \text { Branch }\end{array} & \begin{array}{l}\text { Direction du } \\ \text { Patrimoine de l'édition }\end{array} \\ \begin{array}{l}\text { 395 Wellington Street } \\ \text { Ottawa ON K1A 0N4 }\end{array} & \begin{array}{l}\text { 395, rue Wellington } \\ \text { Ottana ON K1A ON4 } \\ \text { Canada Oa }\end{array}\end{array}$

Your file Votre référence ISBN: 978-0-494-18364-9 Ourfile Notre référence ISBN: 978-0-494-18364-9

NOTICE:

The author has granted a nonexclusive license allowing Library and Archives Canada to reproduce, publish, archive, preserve, conserve, communicate to the public by telecommunication or on the Internet, loan, distribute and sell theses worldwide, for commercial or noncommercial purposes, in microform, paper, electronic and/or any other formats.

The author retains copyright ownership and moral rights in this thesis. Neither the thesis nor substantial extracts from it may be printed or otherwise reproduced without the author's permission.
AVIS:

L'auteur a accordé une licence non exclusive permettant à la Bibliothèque et Archives Canada de reproduire, publier, archiver, sauvegarder, conserver, transmettre au public par télécommunication ou par l'Internet, prêter, distribuer et vendre des thèses partout dans le monde, à des fins commerciales ou autres, sur support microforme, papier, électronique et/ou autres formats.

L'auteur conserve la propriété du droit d'auteur et des droits moraux qui protège cette thèse. $\mathrm{Ni}$ la thèse ni des extraits substantiels de celle-ci ne doivent être imprimés ou autrement reproduits sans son autorisation.
In compliance with the Canadian

Privacy Act some supporting forms may have been removed from this thesis.

While these forms may be included in the document page count, their removal does not represent any loss of content from the thesis.
Conformément à la loi canadienne sur la protection de la vie privée, quelques formulaires secondaires ont été enlevés de cette thèse.

Bien que ces formulaires aient inclus dans la pagination, il n'y aura aucun contenu manquant. 


\begin{abstract}
In East Greenland polar bears, protein association of organohalogens is an important factor besides lipid accumulation in tissue-specific retention since the highest levels of organohalogen contaminants were found in the liver and blood relative to the fat and brain. The type of halogens also plays a role in tissue-specific accumulation. In the bears, the majority of the chlorinated POP burden was in the fat, while the majority of brominated POP burden was in the liver. With the exception of chlorinated phenolic metabolites, ringed seal blubber is a source for all organohalogens found in the polar bear tissues, the contaminants were found to biomagnify in the bears fat, blood and liver. In the bear's brain, protected by the blood-brain barrier, levels of contaminants were found lower relative to seal blubber. Organohalogen exposure has been reported to disrupt the endocrine system; this could impact the growth and development of the polar bears.
\end{abstract}




\section{LIST OF CONFERENCE ABSTRACTS ASSOCIATED WITH THESIS}

W.A. Gebbink, C. Sonne, R. Dietz, M. Kirkegaard, F.F. Riget, E.W. Born, D.C.G. Muir and R.J. Letcher. Chlorinated and brominated contaminants and their metabolic/ degradation products: bioaccumulation and distribution in East Greenland polar bears (Ursus maritimus) and ringed seals (Phoca hispida). $26^{\text {th }}$ International Symposium on Halogenated Environmental Pollutants and POPs (DIOXIN'2006), Aug. 21-25 2006, Oslo, Norway.

W.A. Gebbink, C. Sonne, R. Dietz, M. Kirkegaard, F.F. Riget, E.W. Born, D.C.G. Muir and R.J. Letcher. Polybrominated diphenyl ethers and degradation products: Bioaccumulation and biotransformation in polar bears and ringed seals from East Greenland. $8^{\text {th }}$ BFR workshop, June 27-29 2006, Toronto, ON, Canada.

W.A. Gebbink, C. Sonne, R. Dietz, M. Kirkegaard, F.F. Riget, E.W. Born, D.C.G. Muir and R.J. Letcher. Polybrominated diphenyl ethers and degradation products: Bioaccumulation and biotransformation in polar bears and ringed seals from East Greenland. OCCI Day 2006, Carleton University, May 19 2006, Ottawa, ON, Canada.

W.A. Gebbink, C. Sonne, R. Dietz, M. Kirkegaard, F.F. Riget, E.W. Born, D.C.G. Muir and R.J. Letcher.Polybrominated diphenyl ethers and degradation products: Bioaccumulation and biotransformation in polar bears and ringed seals from East Greenland. $16^{\text {th }}$ Annual Meeting of SETAC-Europe, May 7-11 2006, The Hague, The Netherlands.

W.A. Gebbink, C. Sonne, R. Dietz, M. Kirkegaard, F.F. Riget, E.W. Born, D.C.G. Muir and R.J. Letcher. Tissue distribution and bioaccumulation of halogenated phenolic compounds in polar bears and ringed seals from East Greenland. $16^{\text {th }}$ Annual Meeting of SETAC-Europe, May 7-11 2006, The Hague, The Netherlands.

W.A. Gebbink, C. Sonne, R. Dietz, M. Kirkegaard, F.F. Riget, E.W. Born, D.C.G. Muir and R.J. Letcher. Novel organohalogens and metabolites in the brain of polar bears (Ursus maritimus) from East Greenland. $25^{\text {th }}$ International Symposium on Halogenated Environmental Pollutants and POPs (DIOXIN'2005), Aug. 21-26 2005, Toronto, ON Canada; Organohalogen Compounds, pp. 986-989.

W.A. Gebbink, C. Sonne, R. Dietz, M. Kirkegaard, F.F. Riget, E.W. Born, D.C.G. Muir and R.J. Letcher. PCBs and PCB metabolites in fat, blood and brain of polar bears (Ursus maritimus) from East Greenland. 25 ${ }^{\text {th }}$ International Symposium on Halogenated Environmental Pollutants and POPs (DIOXIN'2005), Aug. 21-26 2005, Toronto, ON Canada; Organohalogen Compounds, pp. 958-961. 


\section{ACKNOWLEDGMENTS}

I would most of all like to acknowledge my supervisor, Dr. Robert Letcher. Rob gave me the opportunity to come to Canada three years ago. Working for Rob the first year, he got me enthusiastic and motivated to start a Masters degree. During this period Rob's door was always open, I could always count on positive feedback and encouragements. I would like to express my sincere gratitude for all his understanding and guidance.

I would really like to thank all the people and organizations who made it possible for this project to succeed. There were numerous people involved in the polar bear and ringed seal sample collection and making them available for this project. I would like to thank Christian Sonne, Rune Dietz, Maja Kirkegaard and Frank Riget from the National Environmental Research Institute in Denmark, Eric Born from Greenland Institute of Natural Resources and Derek Muir from NWRI, Environment Canada. Besides the local hunters I would like to thank the people in the field include Jonas Brønlund who gathered the samples through local hunters, Hanne Tuborg Sandell and Birger Sandell who helped with local contacts to hunters.

I would like to thank all of the present and past people in the lab groups at NWRC and GLIER, especially: Francisco, Soheila, Lewis, Melissa, Karlis, Franco, Wenyi, Shoagang, and Hongxia. I would also like to express my appreciation to all of the kind and helpful people at GLIER and NWRC for creating a unique and enjoyable place to work. I would like to thank Michael Mulvihill for all help and advice in the lab and Francois Cyr for his 
assistance with the GC-HRMS analysis. Finally, I would like to thank my parents, Anton and Henny, for all their support, and most of all Suranika, for her patience and her help.

This project was made possible by the financial support of the Natural Science and Engineering Research Council of Canada and the Canada Research Chairs Program (to R.J. Letcher) 


\section{TABLE OF CONTENTS}

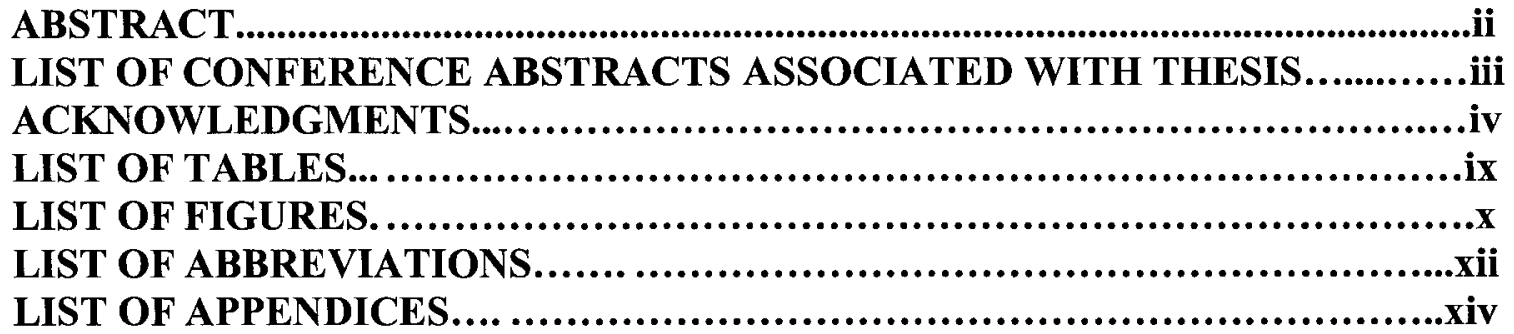

\section{Chapter 1}

General Introduction....................................................1

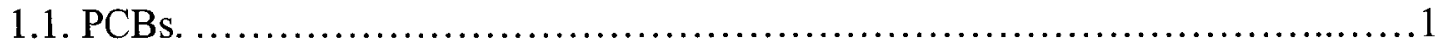

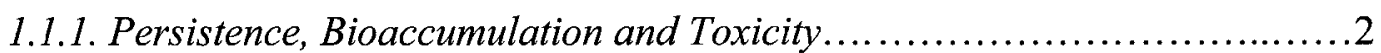

1.2. PBDEs....................................................................

1.2.1. Persistence, Bioaccumulation and Toxicity ................................ 4

1.3. HBCDs..................................................................6

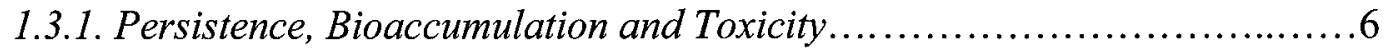

1.4. BIOTRANSFORMATION................................................ 7

1.4.1. Phase I and II reactions.................................................. 8

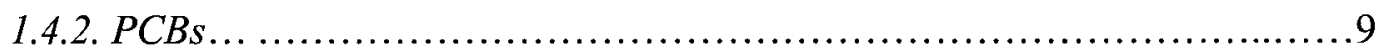

1.4.3. PBDEs......................................................11

1.5. Organohalogen bioaccumulation and body/tissue composition in polar bears....12

1.5.1. Polar bear population dynamics and predator-prey relation............... 12

1.5.2. Organohalogen bioaccumulation from ringed seals to polar bears........13

1.5.3. Organohalogen related health concerns in polar bears...................16

1.6. THESIS OBJECTIVES ................................................. 17

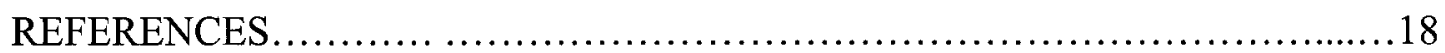

\section{Chapter 2}

Materials and Methods......................................................30

2.1. SAMPLE COLLECTION.................................................. 30

2.1.1. Polar bear tissues................................................. 30

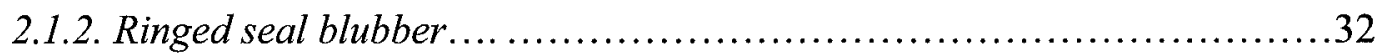

2.2. CHEMICALS AND STANDARDS...................................... 32

2.3. CONTAMINANT EXTRACTION.. ..................................... 33

2.3.1. Polar bear fat ........................................................33

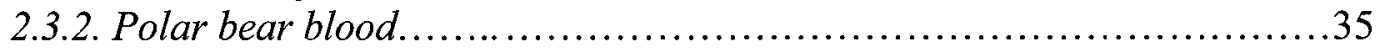

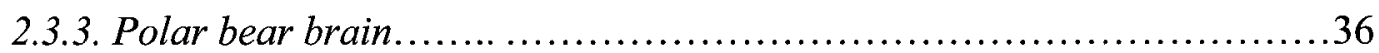

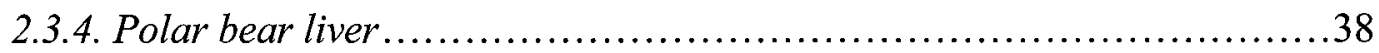

2.3.5. Ringed seal blubber............................................... 38

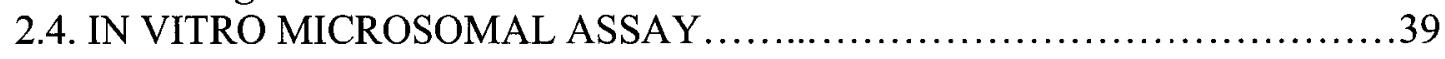

2.5. DETERMINATION OF CONTAMINANTS .............................40

2.5.1. PCBs......................................................4 41

2.5.2. OC pesticides.................................................. 42 


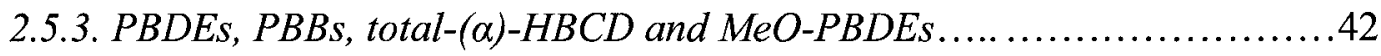

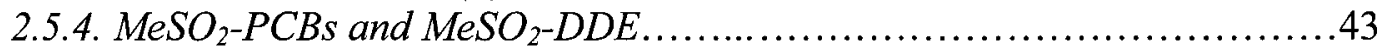

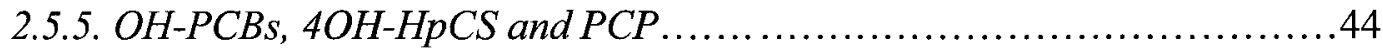

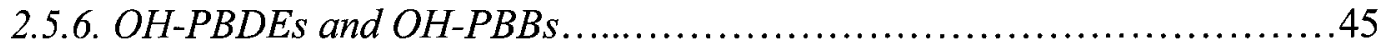

2.6. QUALITY CONTROL AND ASSURANCE..............................46

2.7. DATA ANALYSIS....................................................... 49

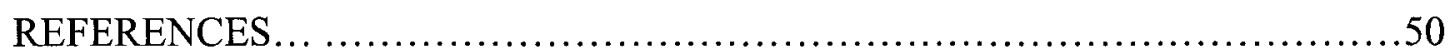

Chapter 3

Tissue-Specific Composition of Brominated and Chlorinated

Contaminants and Metabolically-Associated Compounds in Polar Bears

(Ursus maritimus) from East Greenland... ...............................53

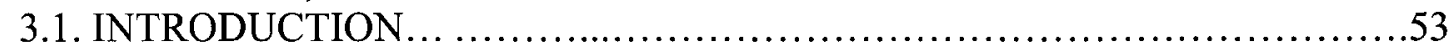

3.2. RESULTS AND DISCUSSION ......................................... 55

3.2.1. Influence of sex ......................................................56

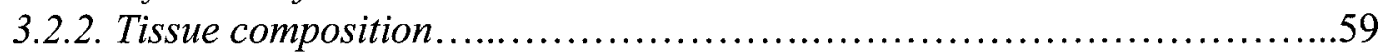

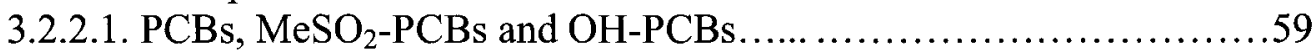

3.2.2.2. Other chlorinated phenolics.................................72

3.2.2.3. Brominated compounds and degradation products..................73

3.2.3. Comparisons and contrasts with 'legacy' organohalogen POPs............85

3.2.4. Total tissue and body burden of organohalogens......................87

3.2.5. Implications of organohalogen exposure and tissue composition in polar bears....................................................... 90

REFERENCES... ....................................................94

\section{Chapter 4}

Bioaccumulation and Biotransformation of Brominated and

Chlorinated Organohalogens and By-Products from Ringed Seals to

Polar Bears from East Greenland......................................102

4.1. INTRODUCTION ..................................................... 102

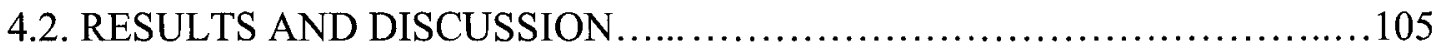

4.2.1. Organohalogens in ringed seals.................................. 105

4.2.1.1. PCBs and PCB metabolites....................................106

4.2.1.2. Chlorinated metabolites and phenolics..........................108

4.2.1.3. Brominated compounds.................................... 109

4.2.1.4. Legacy organochlorine POPs.................................111

4.2.2. Bioaccumulation and biomagnification potential........................111

4.2.2.1. PCBs and PCB metabolites.....................................112

4.2.2.2. Chlorinated metabolites and phenolics...........................116

4.2.2.3. Brominated compounds........................................ 117

4.2.2.4. PBBs and possible OH-PBB metabolites......................127

4.2.2.5. Comparisons and contrasts with "legacy" organochlorine POPs....128

4.2.3. Conclusion and implications... .................................... 129

REFERENCES............................................................ 132 


\section{Chapter 5}

\section{Conclusions}

Future directions ......................................................... 141

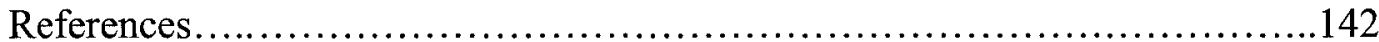




\section{LIST OF TABLES}

Table 1.1. Current knowledge about organohalogen contaminants in ringed seals and polar bears................................................................... 15

Table 3.1. The mean ( \pm SE) of concentrations ( $\mathrm{ng} / \mathrm{g}$ ) of classes of neutral and phenolic organohalogen compounds in female and male polar bear tissues from East Greenland...

Table 3.2. The mean ( $\pm \mathrm{SE}$ ) of concentrations $(\mathrm{ng} / \mathrm{g})$ of classes of neutral and phenolic organohalogen compounds in female and male polar bear tissues from East Greenland $(\mathrm{n}=20)$

Table 3.3. The mean $( \pm \mathrm{SE})$ of the ratios of the sum $(\Sigma)$ OH-PCB to $\Sigma$-PCB, $\Sigma-\mathrm{MeSO}_{2-}$ PCB to $\Sigma$-PCB and $\Sigma$-OH-PBDE to $\Sigma$-PBDE concentrations in fat, blood, brain and liver in East Greenland polar bears.

Table 3.4. The mean ( $\pm \mathrm{SE}$ ) of concentrations (ng/g ww) of apparent $\mathrm{OH}-\mathrm{PBB}$ congeners in female and male polar bear tissues from East Greenland.

Table 3.5. Total amounts $(\mu \mathrm{g} \pm \mathrm{SE})$ of classes of neutral and phenolic organohalogen compounds in the several tissues and blood of female and male polar bear tissues from East Greenland.

Table 4.1. The mean ( \pm SE) of concentrations of classes of neutral and phenolic organohalogen compounds in the blubber of male and female ringed seals from East Greenland $(n=15)$.

Table 4.2. Bioaccumulation factors ( \pm SE) of classes of neutral organohalogen compounds from ringed seals to male and female polar bears from East Greenland.....114

Table 4.3. Bioaccumulation factors $( \pm$ SE) of classes of neutral and phenolic organohalogen compounds from ringed seals to polar bears from East Greenland $(n=20)$. 


\section{LIST OF FIGURES}

Figure 1.1. General chemical structures of brominated and chlorinated contaminants and related metabolites, structural analogues and/or degradation products found in the environment. The hydrogen atoms have been omitted for clarity. $\mathrm{X}$ and $\mathrm{Y}$ indicate the

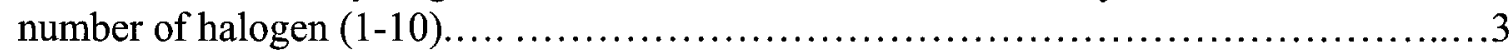

Figure 2.1. Sampling site in East Greenland for ringed seals and polar bears............31

Figure 3.1. Relationship between percent lipid and $\sum-\mathrm{OH}-\mathrm{PCB}$ (ng/g wet weight) in fat

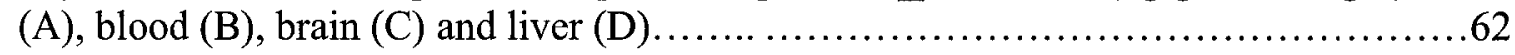

Figure 3.2. Relationship between percent lipid and 4-OH-HpCS (ng/g wet weight) in fat

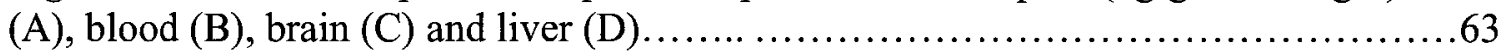

Figure 3.3. Relationship between percent lipid and PCP (ng/g wet weight) in fat (A),

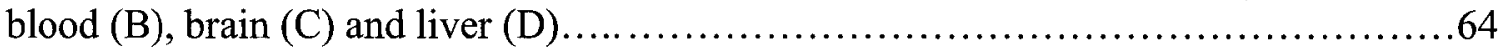

Figure 3.4. The mean ratios of the concentrations of individual PCB congeners to $\Sigma$-PCB in fat (black bars), blood (white bars), brain (stripped bars) and liver (dotted bars) in female (A) and male (B) polar bears from East Greenland. The error bars indicate the \pm $\mathrm{SD}$ of the mean ratios.

Figure 3.5. The mean ratios of the concentrations of individual OH-PCB congeners to $\Sigma$ $\mathrm{OH}-\mathrm{PCB}$ in fat (black bars), blood (white bars), brain (stripped bars) and liver (dotted bars) in female (A) and male (B) polar bears from East Greenland. The error bars indicate the \pm SD of the mean ratios.

Figure 3.6. The mean ratios of the concentrations of individual $\mathrm{MeSO}_{2}-\mathrm{PCB}$ congeners to $\Sigma-\mathrm{MeSO}_{2}-\mathrm{PCB}$ in fat (black bars), blood (white bars), brain (stripped bars) and liver (dotted bars) in female (A) and male (B) polar bears from East Greenland. The error bars indicate the $\pm \mathrm{SD}$ of the mean ratios.

Figure 3.7. The mean ratios of the concentrations of individual PBDE congeners to $\Sigma$ PBDE in fat (black bars), blood (white bars), brain (stripped bars) and liver (dotted bars) in male and female $(n=20)$ polar bears from East Greenland. The error bars indicate the \pm $\mathrm{SD}$ of the mean ratios............................................................ 76

Figure 3.8. The mean ratios of the concentrations of individual MeO-PBDE congeners to $\Sigma$-MeO-PBDE in fat (black bars), blood (white bars), brain (stripped bars) and liver (dotted bars) in male and female $(\mathrm{n}=20)$ polar bears from East Greenland. The error bars indicate the $\pm \mathrm{SD}$ of the mean ratios. 
Figure 3.9. GC-MSD (ECNI) $(\mathrm{m} / \mathrm{z}$ 79/81) chromatogram of the brominated phenolic compound fraction from polar bear fat (derivatized to their corresponding $\mathrm{MeO}$ -

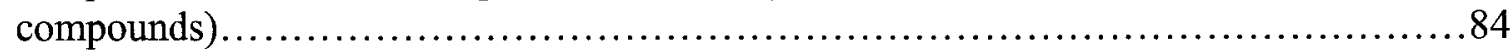

Figure 4.1. Mean ratios of the concentration of PCB congeners to the sum PCB concentrations in ringed seal blubber (black bars) and polar bear fat (white bars). The error bars indicate the \pm SD of the mean ratios.................................... 118

Figure 4.2. Mean ratios of the concentration of $\mathrm{MeSO}_{2}-\mathrm{PCB}$ congeners to the sum $\mathrm{MeSO}_{2}-\mathrm{PCB}$ concentrations in ringed seal blubber (black bars) and polar bear fat (white bars). The error bars indicate the $\pm \mathrm{SD}$ of the mean ratios. .119

Figure 4.3. Mean ratios of the concentration of PBDE congeners to the sum PBDE concentrations in ringed seal blubber (black bars) and polar bear fat (white bars). The error bars indicate the \pm SD of the mean ratios.

Figure 4.4. Mean ratios of the concentration of MeO-PBDE congeners to the sum MeOPBDE concentrations in ringed seal blubber (black bars), polar bear fat (white bars), blood (stripped bars) and liver (dotted bars). The error bars indicate the \pm SD of the mean ratios. 121

Figure 4.5. Fraction of the BDE congener concentration remaining after a $90 \mathrm{~min}$ in vitro assay using hepatic microsomes from polar bear. The dotted lines signify no depletion. Significant depletion $(\mathrm{p}<0.05)$ is marked by an asterisk. Error bars represent \pm SD for replicate assays $(n=3)$. 125 


\section{LIST OF ABBREVIATIONS}

\begin{tabular}{|c|c|}
\hline 4-OH-HpCS & - 4-hydroxy-heptachlorostyrene \\
\hline BAF & - bioaccumulation factor \\
\hline $\mathrm{BBB}$ & - blood-brain barrier \\
\hline BFR & - brominated flame retardant \\
\hline $\mathrm{BMF}$ & - biomagnification factor \\
\hline $\mathrm{CHL}$ & - chlordane \\
\hline $\mathrm{CSF}$ & - cerebrospinal fluid \\
\hline DCM & - dichloromethane \\
\hline$p, p^{\prime}-\mathrm{DDD}$ & - bis-2,2-(4-chlorophenyl)-1,1-dichloroethane \\
\hline$p, p$ '-DDE & - bis-2,2-(4-chlorophenyl)-1,1-dichloroethene \\
\hline$p, p^{\prime}-\mathrm{DDT}$ & - bis-2,2-(4-chlorophenyl)-1,1,1-trichloroethane \\
\hline ECNI & - electron capture negative ionization \\
\hline EI & - electron impact \\
\hline EROD & - ethoxyresorufin O-deethylase \\
\hline FABP & - fatty acid binding protein \\
\hline GC-MSD & - gas chromatography - mass selective detector \\
\hline GC-MS-ECNI & $\begin{array}{l}\text { - gas chromatography - mass spectrometry - electron capture } \\
\text { negative ionization }\end{array}$ \\
\hline GC-HRMS-EI & $\begin{array}{l}\text { - gas chromatography - high resolution mass spectrometry - } \\
\text { electron ionization }\end{array}$ \\
\hline GPC & - gel permeation chromatography \\
\hline GST & - glutathione-S-transferase \\
\hline HBCD & - hexabromocyclododecane \\
\hline $\mathrm{HCB}$ & - hexachlorobenzene \\
\hline $\mathrm{HCH}$ & - hexachlorohexane \\
\hline $\mathrm{HPC}$ & - halogenated phenolic conpounds \\
\hline IS & - internal standard \\
\hline MAP & - mercapturic acid pathway \\
\hline MeO-PBB & - methoxy-polybrominated biphenyl \\
\hline MeO-PBDE & - methoxy-polybrominated diphenyl ether \\
\hline $\mathrm{MeSO}_{2}-\mathrm{DDE}$ & - methyl sulfonyl-2,2-(4-chlorophenyl)-1,1-dichloroethene \\
\hline $\mathrm{MeSO}_{2}-\mathrm{PCB}$ & - methyl sulfonyl-polychlorinated biphenyl \\
\hline MLOQ & - method limit of quantitiation \\
\hline MROD & - methoxyresorufin O-deethylase \\
\hline MtBE & - methyl tert-butyl ether \\
\hline $\mathrm{NADPH}$ & - nicotinamide adenine dinucleotide phosphate \\
\hline NWRC & - National Wildlife Research Centre \\
\hline OC pesticides & - organochlorine pesticides \\
\hline OCS & - octachlorostyrene \\
\hline OH-PBB & - hydroxy-polybrominated biphenyl \\
\hline OH-PBDE & - hydroxy-polybrominated diphenyl ether \\
\hline OH-PCB & - hydroxy-polychlorinated biphenyl \\
\hline PAH & - polycyclic aromatic hydrocarbon \\
\hline
\end{tabular}




$\begin{array}{ll}\text { PBB } & \text { - polybrominated biphenyl } \\ \text { PBDE } & \text { - polybrominated diphenyl ether } \\ \text { PCB } & \text { - polychlorinated biphenyl } \\ \text { PCP } & \text { - pentachlorophenol } \\ \text { PeClBz } & \text { - pentachlorobenzene } \\ \text { PFK } & \text { - perfluorokerosine } \\ \text { PFOS } & \text { - perfluorooctane sulfonate } \\ \text { POP } & \text { - persistent organohalogen pollutant } \\ \text { PROD } & \text { - pentoxyresorufin-O-depentylase } \\ \text { RBA } & \text { - relative binding affinity } \\ \text { RBP } & \text { - retinol binding protein } \\ \text { RRF } & \text { - relative response factor } \\ \text { SD } & \text { - standard deviation } \\ \text { SE } & \text { - standard error } \\ \text { SIM } & \text { - selected ion monitoring } \\ \text { SRM } & \text { - standard reference material } \\ \text { SULT } & \text { - sulfotransferase } \\ \text { T4 } & \text { - thyroxine } \\ \text { TeClBz } & \text { - tetrachlorobenzene } \\ \text { TMP } & -2,2 \text { ',4-trimethylpentane } \\ \text { TTR } & \text { - transthyretin } \\ \text { UDPGT } & \text { - uridine diphosphoglucuronosyl transferase } \\ & \end{array}$




\section{LIST OF APPENDICES}

Appendix 1 - Sample information of polar bears collected in 1999-2001 in central East

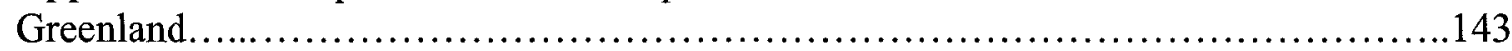

Appendix 2 - Sample information of ringed seals collected in 2002 in central East Greenland. 144

Appendix 3 - GC-MSD (ECNI) full scan mass spectra (50-550 amu) of unknown OHPBBs. 


\section{CHAPTER 1}

\section{General Introduction}

Contamination of the environment and it inhabitants by anthropogenic halogenated organic chemicals has been occurring since the early twentieth century. The use of dichloro-diphenyl-trichloroethane (DDT) as an insecticide and polychlorinated biphenyls (PCBs) as electrical insulators required large scale production. Due to factors such as accidental release or leakages from consumer products, PCBs and DDT are among environmentally relevant chemicals commonly reffered to as persistent organohalogen pollutants (POPs) (Tanabe, 1988). In the late twentieth century the use of the the additive brominated flame retardant (BFRs) classes such as polybrominated diphenyl ethers (PBDEs) and hexabromocyclododecanes (HBCDs) lead to an increase in the presence these contaminants in the environment, including the Arctic (Ikonomou et al., 2000). Years after the restriction on the production of PCBs and pesticides, as well as the banning of some BFRs, they continue to be found in the environment and in biota. There is increasing evidence available for many POPs demonstrating various toxicological and biological effects in wildlife and humans (Hardy et al., 2002; Fonnum et al., 2006; Lillenthal et al., 2006).

\subsection{PCBs}

There are theoretically 209 different PCB isomers and congeners, consisting of 1 to 10 chlorine atoms around a biphenyl ring system (Figure 1.1). A systematic numbering system for PCBs was developed by Ballschmiter et al. (1991). PCBs were used mainly 
as electrical insulators, $10 \%$ of the possible congeners were present in technical mixtures (De Voogt et al., 1989). PCBs are released into the environment mainly through leakage from currently used products and also from landfills (Tanabe, 1988). After entering the environment, PCBs may undergo volatilization to the atmosphere followed by deposition to terrestrial and aquatic media, resulting in their long-range transport (Ballschmiter et al., 1991). Favourable physico-chemical properties of PCBs such as $\log \mathrm{K}_{\text {ow }}$ has resulted in their presence globally in abiotic and biotic media, including the Arctic (Muir et al., 1988; Gioia et al., 2006; Drouillard et al., 2006).

\subsubsection{Persistence, Bioaccumulation \& Toxicity}

The inertness of PCBs in environmental media resultes in slow degradation (Tanabe, 1988; Ballschmiter et al., 1991). In biota PCBs are generally slow to be metabolized and slowly excreted resulting in bioaccumulation (Sijm, 2001). Upon deposition in marine and other aqueous environments, PCBs readily bioconcentrate in low trophic organisms due to their hydrophobic nature (Thomann, 1989). PCBs have $\log K_{\text {ow }}$ ranging from $4.5-$ 8 depending on the chlorination (Padmanabhan et al., 2006). Food chain and trophic level transfer of PCBs results in elevated levels in top predators (biomagnification), including those in the Arctic, such as marine mammals and seabirds (Braune et al., 2005). In PCB exposed laboratory animals, thyroidogenic, estrogenic and androgenic effects have been reported, as well as related neurobehavioral, reproductive and developmental toxicities (Ulbrich and Stahlmann, 2004). 

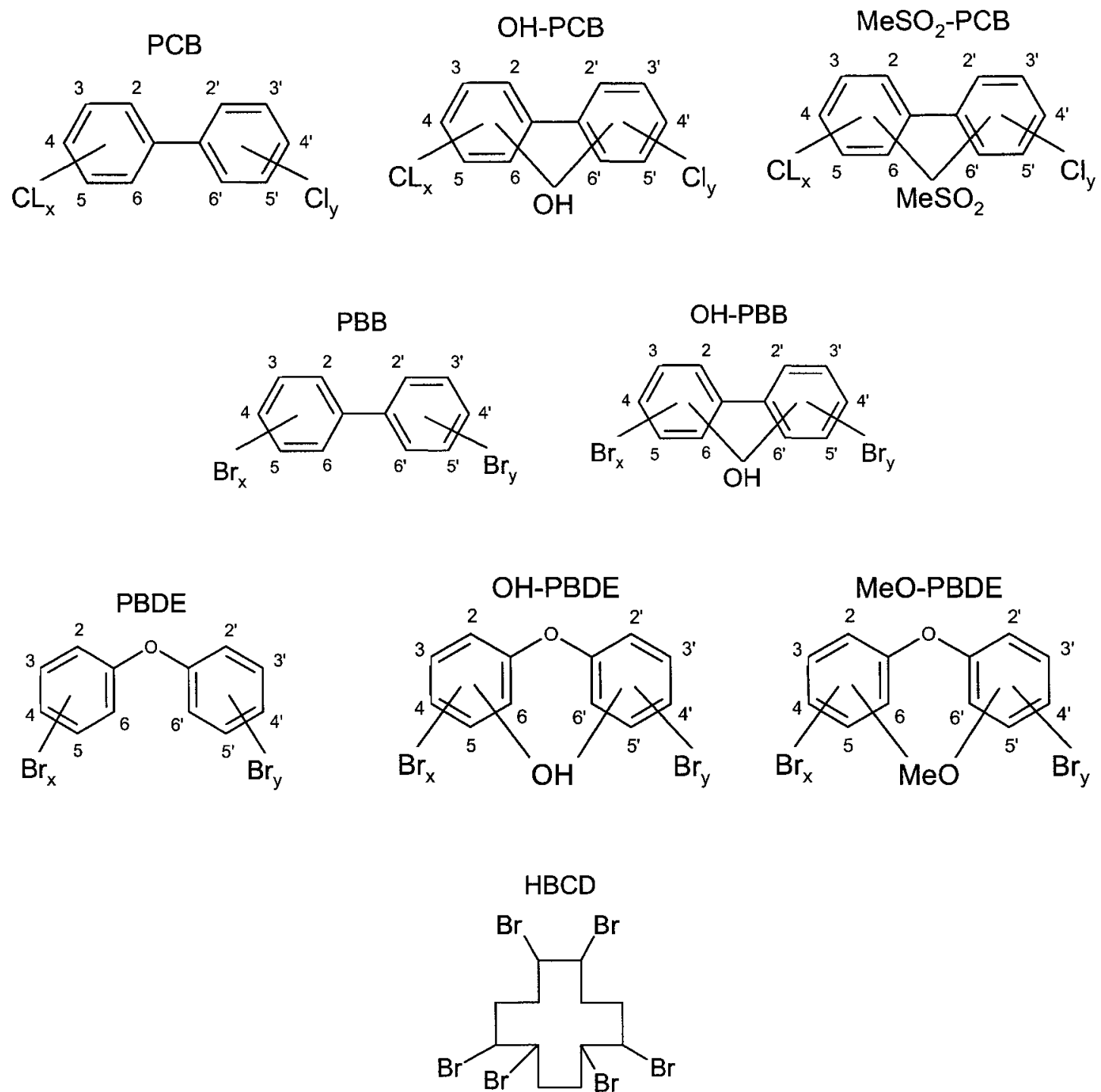

Figure 1.1. General chemical structures of brominated and chlorinated contaminants and related metabolites, structural analogues and/or degradation products found in the environment. The hydrogen atoms have been omitted for clarity. $\mathrm{X}$ and $\mathrm{Y}$ indicate the number of halogen (1-10). 


\subsection{PBDEs}

There are theoretically 209 different congeners, and the two biphenyl rings are separated by an ether linkage and contain 1 to 10 bromine atoms (Figure 1.1). The systematic numbering system developed by Ballschmiter et al. (1991) for PCB congeners was adopted for the corresponding PBDE congeners. PBDEs are produced and used as flame retardants and are added in polymers, which are used in electrical and electronical equipments, paints, textiles, and in cars and aircraft (De Boer et al., 2000). Only several congeners are used in technical mixtures. The penta-BDE mixture consists mainly of BDE-47 and BDE-99, as well as minor amount of tri- and hexa-PBDEs. The octa-BDE mixture consists mainly of BDE-153, BDE-154 and BDE-183, beside those congeners minor amounts of octa- and nona-PBDE congeners were present. The deca-BDE mixture consisted almost entirely of BDE-209, traces of nona-PBDEs are also present (De Boer et al., 2000; Alaee et al., 2003). PBDEs are released into the environment from manufacturing facilities, landfills and leaching from products in use (Darnerud et al., 2001). From air to water and sediment to wildlife, PBDEs have been detected in virtually all abiotic and biotic media in various regions in the world (De Boer et al., 2000; Hale et al., 2006; De Wit et al., 2006).

\subsubsection{Persistence, Bioaccumulation \& Toxicity}

PBDEs persist in the environment, although they can be degraded slowly (De Boer et al., 2000). In vitro biotransformation tests have confirmed the persistency of PBDEs, no depletion was observed of PBDE congners during an in vitro bioassay using dolphin liver 
microsomes, they were found to be more persistent than PCBs (De Boer et al., 1998). Photodegradation of PBDEs in organic solvents or water was shown after irradiation with ultra violet radiation and sunlight (Eriksson et al., 2004). PBDE levels in humans and wildlife have increased exponentially over the last few decades (Ikonomou et al., 2000; Schecter et al., 2003), and in human serum, half-lives have been estimated between 15 days to $>3$ months (Thuressen et al., 2006), in trout half-lives can be up to $>1$ year depending on the congener (Tomy et al., 2004). PBDEs have hydrophobic properties, $\log K_{\text {ow }}$ ranges, depending on the number of bromination, between $5.8-10$ and tend to concentrate on particulate matter and in biota (De Boer et al., 2000). In all levels of food webs, from plankton and fish to birds and mammals, PBDEs have been found in various tissues (De Wit et al., 2002, 2006). In marine food webs PBDE levels increase in species higher up the food chain and trophic levels (Booij et al., 2002; Wolkers et al., 2004). Over the last few years, there is increasing evidence that PBDEs have endocrine disrupting potencies (Darnerud et al., 2001; Legler and Brouwer, 2003; Hamers et al., 2006). Mice exposed to the penta-PBDE technical mixture showed significant reduced serum thyroxine (T4) levels (Fowles et al., 1994). In vitro studies showed no or very low (1\%) competition of PBDE with T4 to the binding to human TTR (Legler and Brouwer, 2003; Hamers et al., 2006). Meerts et al. (2001) demonstrated that a number of PBDE congeners act as xenoestrogens in an in vitro human cellular assay. PBDEs have the ability to induce phase I and II enzyme activities. Induction of the phase I enzymes, EROD and MROD, and phase II enzyme UDPGT, was seen in laboratory rats orally dosed with BDE-47 (Hallgren and Darnerud, 2002). 


\subsection{HBCDs}

Hexabromocyclododecane (HBCD) is a nonaromatic, brominated cyclic alkane (Figure 1.1). The commercial HBCD product is composed of three stereoisomers: $\alpha-, \beta$ - and $\gamma$ HBCD, the assignment of the Greek letters is based on the order of elution from a reversed-phase $\left(\mathrm{C}_{18}\right)$ liquid chromatography column (Tomy et al., 2005). Like PBDEs, HBCD is also used as a flame retardant and is added to polystyrene foam used in textiles and electrical equipment (Covaci et al., 2006). Technical HBCD typically consists primarily of $\gamma-\mathrm{HBCD}$, while $\alpha$ - and $\beta-\mathrm{HBCD}$ are represented in lower amounts (Brinbaum et al., 2004). HBCD can enter the environment by a number of different pathways, emission during production of HBCD or manufacturing of flame-retarded products and leaching from consumer products (Remberger et al., 2004; Covaci et al., 2006). In sediment and soil $\gamma-\mathrm{HBCD}$ is the primary stereoisomer, $\alpha$ - and $\beta$-HBCD minor, in air $\alpha-$ and $\gamma$-HBCD are both dominant stereoisomers, and in biota $\alpha$-HBCD is the primary stereoisomer (Covaci et al., 2006).

\subsubsection{Persistence, Bioaccumulation \& Toxicity}

Like other BFRs, HBCD is highly lipophilic and has a $\log K_{\mathrm{ow}}$ of 5.6 and has a half-live of 3 days in air and 2-25 days in water (Birnbaum et al., 2004). The $\operatorname{logK}_{\text {ow }}$ is defined as the ratio of the chemical's concentration in the octanol phase to its concentration in the aqueous pahse. In the North Sea, HBCD has been detected in various species with increasing concentration in species higher up in the food web (Morris et al., 2004). In California sea lions stranded between 1993 and 2003, an increase in HBCD blubber concentrations was observed from $<0.4 \mathrm{ng} / \mathrm{g}$ in 1993 to $96 \mathrm{ng} / \mathrm{g}$ lipid weight in 2003 
(Stapleton et al., 2005). Oral exposure to HBCD in rats induced hepatic cytochrome P450 enzymes (Germer et al., 2006). Also, in rats HBCD can disrupt the thyroid hormone system (Darnerud, 2003).

\subsection{Biotransformation}

The biological fate of a contaminant depends on uptake, distribution, metabolism and excretion. Toxicokinetics is defined as the process of the uptake of potentially toxic substances by the body, the biotransformation they undergo, the distribution of the substances and their metabolites in the tissues, and the elimination of the substances and their metabolites from the body. Both the amounts and the concentrations of the substances and their metabolites are studied. The term has essentially the same meaning as pharmacokinetics, but the latter term should be restricted to the study of pharmaceutical substances. Biotransformation influences the residence time, or half-life, of a contaminant in an organism through catalytic formation of more hydrophilic and thus more readily excretable metabolites. This process should primarily result in detoxification of POPs. The formation of oxidative metabolites, which are more polar that the contaminants, leads to a faster elimination of the contaminants. However, metabolism may be a bioactivation process leading to the formation of retained metabolites that are toxicologically active. Thus, not only the toxicokinetics, but also the inherent toxicity of a compound depends on metabolic conversion. 


\subsubsection{Phase I and II reactions}

Biotransformation reactions are categorized as phase I and phase II processes. In phase I, xenobiotics are oxidized, hydrolyzed or reduced to apparently less hydrophobic metabolites. In phase II, these metabolites are conjugated to larger, hydrophilic endogenous molecules, which increases the succeptibility for excretion from an organism. The phase I cytochromes P450 (CYP) are a superfamily of heme-based enzymes found in mammals, fish, birds and microorganisms. In mammals, the highest CYP activity is in the smooth endoplasmic reticulum of the liver. Most foreign compounds, including environmental pollutants, drugs and antibiotics, as well as endogenous compounds, such as steroids, bile acid, fatty acids and prostaglandins are biotransformed by CYP enzymes (Goksøyr and Förlin, 1992; Lewis et al., 1998). CYP1A, CYP2B, CYP3A, CYP2E and epoxide hydrolase (EH) are major isoforms of CYP sub-families mediating the phase I metabolism of anthropogenic compounds (Nebert et al., 1991). The main phase II enzyme systems are the glutathione-Stransferases (GSTs), uridine diphosphoglucuronosyl transferases (UDPGTs) and sulfotransferases (SULTs) (George, 1994; Wolkers et al., 1998). GSTs mediate the conjugation of glutathione to arene epoxide bearing phase I intermediates. UDPGTs and/or SULTs mediate the conjugation of glucuronic acid and 3'-phosphoadenosine-5'phosphosulfate (PAPS), respectively, to the OH-group of phenols, for instance. Although these processes were previously thought of as detoxifying, it is now known that for many organic contaminants, intoxication may be the result of biotransformation (e.g. polycyclic aromatic hydrocarbons, PAHs) (Stine and Brown, 1996). The induced and constitutive levels of individual CYP and phase II enzymes are species- and population-specific 
(Smith, 1991), and activities are dependent on exposure to enzyme-inducing xenobiotics including some POPs. For Canadian polar bears, the presence of CYP1A, CYP2B, CYP2C, CYP3A and epoxide hydrolase have been determined in the liver (Bandiera et al., 1995, 1997; Letcher et al., 1996). Phase II conjugation of phase I metabolites has also been observed in polar bear livers via UDPGTs and SULTs (Sacco and James, 2004, 2005).

\subsection{2. $P C B s$}

Interactions of some PCB congeners with metabolic enzyme systems have been reported in some marine mammals. In beluga whales from the Canadian Arctic, there was a correlation between immunodetectable CYP1A and adipose levels of ortho-substituted coplanar PCB congeners (White et al., 1994). In polar bears from the Canadian Arctic CYP1A were correlated to the hepatic levels of mono-ortho-PCBs, and CYP2B to the hepatic levels of ortho-PCBs (Letcher et al., 1996). Phase I metabolites of PCBs, OHPCBs (Figure 1.1.), have been found in polar bears as well as other marine mammals, humans, birds and fish (Sandau et al., 2000; Fängström et al., 2002; Hovander et al., 2002; Hoekstra et al., 2003; Sandala et al., 2004; Verreault et al., 2005; McKinney et al., 2006), suggesting the general presence of these secondary contaminants in biota. The CYP-mediated biotransformation of PCBs to $\mathrm{OH}-\mathrm{PCB}$ proceeds by either arene epoxide formation or subsequent ring opening or by direct $\mathrm{OH}$-insertion on the biphenyl ring (Letcher et al., 2000). Regardless, there is a lack of information about bioaccumulation of $\mathrm{OH}-\mathrm{PCB}$ in fat, in humans, $\mathrm{OH}-\mathrm{PCBs}$ were found to accumulate in fat (Guvenius et al., 2002). Besides accumulation in lipid, OH-PCBs are retained in biota due to an 
affinity for binding a transport protein, transthyretin (TTR), that can be up to ten times higher than the natural ligand, thyroxine (T4). In general, only OH-PCBs formed from higher chlorinated parent $\mathrm{PCBs}$ with the $\mathrm{OH}$-group in the para- or sometimes metaposition are retained, whereas most $\mathrm{OH}-\mathrm{PCBs}$ are readily conjugated and eliminated. In polar bears the efficiency of glucuronidation of lower chlorinated OH-PCBs was around ten times lower than of higher chlorinated OH-PCBs (Sacco and James, 2004). In laboratory rodents, it has been demonstrated that these metabolites are thyroidogenic due to competitive binding to TTR, disturb the thyroid hormone metabolism and alter vitamin A levels (Brouwer et al., 1986, 1988).

Phase II conjugation of 3,4-epoxide PCB intermediates with endogenous tripeptide glutathione (GSH) occurs via glutathione-S-transferase (GST). After dehydration, the glutathionyl-PCB (PCB-SG) conjugate undergoes peptidase hydrolysis via the mercapturic acid pathway (MAP). The mercapturic acid conjugate is converted into a thiol (-SH), which is subsequently methylated to methylthio-(MeS)PCB. A two step oxidation converts MeS-PCB to a MeSO-PCB and then to a $\mathrm{MeSO}_{2}-\mathrm{PCB}$ (Figure 1.1.) (Letcher et al., 1998, 2000; Sandala et al., 2004; Verreault et al., 2005). Methyl sulfone metabolites of PCBs have been found in polar bears (Letcher et al., 1995, 1998), other marine mammals (Letcher et al., 2000b; Hoekstra et al., 2003; McKinney et al., 2006) as well as humans (Chu et al., 2003). Many of these congeners are hydrophobic enough to accumulate in fatty tissues, also tissue selective retention of a $\mathrm{MeSO}_{2}-\mathrm{PCB}$ congener in liver and lung has been seen due to protein binding (Larsen et al., 1991, 1992; Haraguchi et al., 1997). In general, the biologically retained congeners are meta- and para- $\mathrm{MeSO}_{2}-$ substituted, resulting in a pair of isomers, with the chlorine substitution on the $\mathrm{MeSO}_{2-}$ 
containing ring at the 2,5- or 2,5,6-positions. $\mathrm{MeSO}_{2}-\mathrm{PCBs}$ have been shown to affect enzyme activities and exhibit endocrine disrupting properties. Some 3- and 4- $\mathrm{MeSO}_{2}-$ PCBs reduce thyroid hormone levels in rats (Kato et al., 1998).

\subsubsection{PBDEs}

PBDEs have the ability to induce phase I and II enzyme activities. Induction of the phase I enzymes, EROD and MROD, and phase II enzyme UDPGT, was seen in laboratory rats orally dosed with BDE-47 (Hallgren and Darnerud, 2002). Limited data exists regarding the metabolism of PBDEs in marine mammals (Hakk and Letcher, 2003). Residue patterns in higher trophic organisms are nonetheless suggestive of metabolism (Boon et al., 2002; Ikonomou et al., 2002; Wolkers et al., 2004). For instance, BDE100 appeared to be relatively depleted in comparison to prey species in both habour seal (Boon et al., 2002) and ringed seal (Wolkers et al., 2004). OH-PBDE and MeO-PBDEs have been detected in polar bears from Svalbard (Verreault et al., 2005), other marine mammals (Haglund et al., 1997; Wolkers et al., 2004; Teuten et al., 2005) and several fish species (Kierkegaard et al., 2004; Malmvärn et al., 2005; Valters et al., 2005). There is currently a debate as to whether $\mathrm{OH}-$ and $\mathrm{MeO}-\mathrm{PBDE}$ residues found in marine biota are natural products or are the result of PBDE metabolism. Some of the ortho-substituted OH- and MeO-PBDEs are known to be produced by sponges and algae (Carté et al., 1981; Fu et al., 1995; Kurihara et al., 1999; Marsh et al., 2004; Malmvärn et al., 2005; Teuten et al., 2005). 
The possibility that PBDEs may undergo biotransformation processes as the structurally related $\mathrm{PCBs}$, such as via pathways leading to $\mathrm{OH}$-metabolite formation, is supported by the finding in laboratory rodents and some fish species (Hakk et al., 2002, 2003, 2006; Mörck et al., 2003; Sanders et al., 2006; Marsh et al., 2006). Besides several OHmetabolites, sulfur-containing metabolites were also formed in rats exposed to BDE99 (Hakk et al., 2002). Metabolism of BDE209 to OH-metabolites and lower brominated metabolites has been found in orally dosed rats (Mörck et al., 2003). Thus, similar to PCBs, PBDEs are oxidatively metabolized to $\mathrm{OH}$-metabolites, but unlike PCBs, PBDEs are also subject to dehalogenation reactions in laboratory rodents. Increasing evidence has become available that $\mathrm{OH}-\mathrm{PBDEs}$ have endocrine disrupting properties. In human in vitro studies, $\mathrm{OH}-\mathrm{PBDEs}$ exert strong thyroidogenic as well as estrogenic effects (Meerts et al., 2000, 2001, Hamers et al., 2006)

\subsection{Organohalogen Bioaccumulation and Body/Tissue Composition in Polar Bears}

\subsubsection{Polar Bear Population Dynamics and Predator-Prey Relation}

Polar bears predominantly feed on ringed seal (Phoca hispida), although they have been report of bears consuming bearded seals (Erignathus barbatus) (Stirling and Archibald, 1977; Smith, 1980). Opportunistic feeding on other species such as beluga whales (Delphinaterus lerucas) and narwhals (Monodon monoceros) has also been documented for polar bears as well (Derocher et al., 1993, 2000; Smith et al., 1990). However, ringed seal (blubber) has been reported to account for $\geq 98 \%$ of diet of polar bears in the Beaufort Sea. In western Hudson Bay, ringed seals accounted for about $80 \%$ of intake in the early 1990s, indicating the importance of foraging in ice-covered habitat. Recently, 
Iverson et al. (2006) reported that ringed seal consumption by polar bear declined throughout the 1990 s concurrent with progressively earlier ice breakup, while the proportions of bearded and harbour seals increased, suggesting reduced reliance on ice. Regardless, Iverson et al. (2006) used fatty acid signatures as indicators of diet and found that in both northern and southern Beaufort Bay areas that ringed seals comprised about $95 \%$ of the fatty acid signatures of polar bear adipose tissue, with the remainder being made up by bearded seals. Therefore, it appears that generally ringed seal blubber is highly representative of the diet of polar bears.

\subsubsection{Organohalogen Bioaccumulation from Ringed Seals to Polar Bears}

Organohalogen contaminants, like PCBs, OC pesticides, PBDEs and HBCDs, reach the Arctic through long range atmospheric transport (Hung et al., 2005; de Wit et al., 2006). Due to their hydrophobic properties they enter the Arctic food web and bioaccumulate to higher trophic levels (Braune et al., 2005; de Wit et al., 2006). The bioaccumulation of an organohalogen contaminant is defined as the degree to which an organism takes up and retains the contaminants from all applicable exposure routes. Polar bears are exposed to the POPs by consuming large amounts of ringed seal blubber. Levels of PCBs, OC pesticides, $\mathrm{PBDEs}, \mathrm{MeSO}_{2}-\mathrm{PCBs}$ and 3- $\mathrm{MeSO}_{2}-p, p$ '-DDE have been detected in ringed seal blubber in several polar bear populations (Table 1.1.). In many cases the levels of these contaminants increased from seal to polar bear, indicating biomagnification of the contaminants to a higher trophic level (Muir et al., 1988; 2006; Letcher et al., 1998; Wiberg et al., 2000; Kucklick et al., 2002; Wolkers et al., 2004). Biomagnification refers to the tendency of the contaminants to become increasingly concentrated at successively 
higher trophic levels of a food chain or food web. Apart from the studies already mentioned, prey (ringed seal) to predator (polar bear) bioaccumulation is largely unknown for many emerging chlorinated and brominated POPs that have been recently identified in polar bear, especially those of the phenolic variety like OH-PCBs OHPBDEs, 4-OH-HpCS and PCP (Sandau et al., 2000; Sandala et al., 2004; Braune et al., 2005; Verreault et al., 2005).

A trend of increasing $\sum$-PCB levels in ringed seal blubber was seen from the Alaskan and Canadian population to the East Greenland, Svalbard and Russian seal populations (Muir et al., 1988, 2000; Wolkers et al., 1998; Kucklick et al., 2002; Vorkamp et al., 2004). Geographic studies on levels of contaminants in the polar bear populations in the western hemisphere showed a similar trend as with contaminants in the seals, and that in the East Greenland polar bear population the levels of PCBs, OC pesticides, PBDEs and HBCD were amongst, if not the highest in fat (Norstrom et al., 1998; Verreault et al., 2005; Muir et al., 2006). Fat is a well studied tissue with respect to contaminant levels in the polar bear due to the lipophilic character of the contaminants. There are numerous studies of PCBs and OC pesticide levels in fat while the number of reports on emerging POPs like $\mathrm{MeSO}_{2}-\mathrm{PCBs}$, PBDEs and total-( $\left.\alpha\right)$-HBCD is limited (Table 1.1). Established POPs have been studies thoroughly with respect to the presence in the environment, possible toxic effects on biota. For emerging POPs the information on bioaccumulation, toxicity and persistence is still lacking. The accumulation of halogenated phenolic contaminants in polar bear fat has, to our knowledge, not been studied previously. Both legacy and emerging contaminants have all been detected in polar bear blood. The number of 
Table 1.1. Current knowledge about organohalogen contaminants in ringed seals and polar bears.

\begin{tabular}{|c|c|c|c|c|}
\hline Analyte & Species & Tissues & Location $^{\mathrm{a}}$ & Reference \\
\hline PCBs & $\begin{array}{l}\text { Ringed seal } \\
\text { Polar bear }\end{array}$ & $\begin{array}{l}\text { Blubber } \\
\text { Fat } \\
\text { Blood } \\
\text { Liver }\end{array}$ & $\begin{array}{l}\mathrm{Al}, \mathrm{CA}, \mathrm{EG}, \mathrm{Sv}, \mathrm{RA} \\
\mathrm{Al}, \mathrm{CA}, \mathrm{EG}, \mathrm{Sv} \\
\mathrm{CA}, \mathrm{EG}, \mathrm{Vs}, \mathrm{RA} \\
\mathrm{Al}\end{array}$ & $\begin{array}{l}\text { Muir et al., 1988, 2000; Wolkers et al., 1998; Kucklick et al., 2002; Vorkamp et al., } 2004 \\
\text { Bernthof et al., 1997; Norstrom et al., 1998; Dietz et al., 2004; Sandala et al., 2004; } \\
\text { Verreault et al., 2005, 2006 } \\
\text { Bernthof et al., 1997; Andersen et al., 2001; Skaare et al., 2001; Sandau et al., 2000; } \\
\text { Sandala et al., 2004; Oskam et al., } 2004 \\
\text { Kannan et al., 2005 }\end{array}$ \\
\hline OH-PCBs & Polar bear & Blood & $\mathrm{CA}, \mathrm{EG}$ & Sandau et al., 2000; Sandala et al., 2004 \\
\hline $\mathrm{MeSO}_{2}-\mathrm{PCBs}$ & $\begin{array}{l}\text { Ringed seal } \\
\text { Polar bear }\end{array}$ & $\begin{array}{l}\text { Blubber } \\
\text { Fat } \\
\text { Blood } \\
\text { Liver }\end{array}$ & $\begin{array}{l}\mathrm{CA} \\
\mathrm{Al}, \mathrm{CA}, \mathrm{EG}, \mathrm{Sv} \\
\mathrm{EG} \\
\mathrm{CA}\end{array}$ & $\begin{array}{l}\text { Letcher et al., } 1998 \\
\text { Letcher et al., 1998; Sandala et al., 2004; Verreault et al., } 2005 \\
\text { Sandala et al., } 2004 \\
\text { Letcher et al., } 1998\end{array}$ \\
\hline OC pesticides & $\begin{array}{l}\text { Ringed seal } \\
\text { Polar bear }\end{array}$ & $\begin{array}{l}\text { Blubber } \\
\text { Fat } \\
\text { Blood } \\
\text { Liver }\end{array}$ & $\begin{array}{l}\text { Al, CA, EG, Sv, RA } \\
\text { Al, CA, EG, Sv } \\
\text { EG, Sv } \\
\text { CA }\end{array}$ & $\begin{array}{l}\text { Muir et al., 1988, 2000; Wolkers et al., 1998; Kucklick et al., 2002; Vorkamp et al., } 2004 \\
\text { Bernthof et al., 1997; Norstrom et al., 1998; Dietz et al., 2004; Sandala et al., 2004; } \\
\text { Verreault et al., 2005, } 2006 \\
\text { Bernthof et al., 1997; Skaare et al., 2001; Sandala et al., 2004, Oskam et al., } 2004 \\
\text { Wiberg et al., 2000; Kannan et al., 2005 }\end{array}$ \\
\hline 3-MeSO${ }_{2}-p, p^{\prime}-\mathrm{DDE}$ & $\begin{array}{l}\text { Ringed seal } \\
\text { Polar bear }\end{array}$ & $\begin{array}{l}\text { Blubber } \\
\text { Fat } \\
\text { Blood } \\
\text { Liver }\end{array}$ & $\begin{array}{l}\mathrm{CA} \\
\mathrm{Al}, \mathrm{CA}, \mathrm{EG}, \mathrm{Sv} \\
\mathrm{EG} \\
\mathrm{CA}\end{array}$ & $\begin{array}{l}\text { Letcher et al., } 1998 \\
\text { Letcher et al., 1998; Sandala et al., 2004; Verreault et al., } 2005 \\
\text { Sandala et al., } 2004 \\
\text { Letcher et al., } 1998\end{array}$ \\
\hline 4-OH-HpCS & Polar bear & Blood & $\mathrm{CA}, \mathrm{EG}$ & Sandau et al., 2000; Sandala et al., 2004 \\
\hline PCP & Polar bear & Blood & $\mathrm{CA}, \mathrm{EG}$ & Sandau et al., 2000; Sandala et al., 2004 \\
\hline PBDEs & $\begin{array}{l}\text { Ringed seal } \\
\text { Polar bear }\end{array}$ & $\begin{array}{l}\text { Blubber } \\
\text { Fat } \\
\text { Blood } \\
\text { Liver }\end{array}$ & $\begin{array}{l}\mathrm{CA}, \mathrm{EG}, \mathrm{Sv} \\
\mathrm{Al}, \mathrm{CA}, \mathrm{EG}, \mathrm{Sv} \\
\mathrm{Sv} \\
\mathrm{Al}\end{array}$ & $\begin{array}{l}\text { Ikonomou et al., 2002; Wolkers et al., 2004; Vorkamp et al., 2004; Sørmo et al., } 2006 \\
\text { Wolkers et al., 2004; Muir et al., 2006; Sørmo et al., 2006; Dietz et al., } 2006 \\
\text { Verreault et al., 2005 } \\
\text { Kannan et al., 2005 }\end{array}$ \\
\hline Total- $(\alpha)$-HBCD & $\begin{array}{l}\text { Ringed seal } \\
\text { Polar bear }\end{array}$ & $\begin{array}{c}\text { Blubber } \\
\text { Fat } \\
\text { Blood }\end{array}$ & $\begin{array}{l}\mathrm{Sv} \\
\mathrm{Al}, \mathrm{EG}, \mathrm{Sv} \\
\mathrm{Sv}\end{array}$ & $\begin{array}{l}\text { Sørmo et al., } 2006 \\
\text { Muir et al., 2006; Sørmo et al., } 2006 \\
\text { Verreault et al., } 2005 \\
\end{array}$ \\
\hline OH-PBDEs & Polar bear & Blood & Sv & Verreault et al., 2005 \\
\hline $\begin{array}{l}\text { MeO-PBDEs } \\
\text { MeO-PBDEs }\end{array}$ & $\begin{array}{l}\text { Ringed seal } \\
\text { Polar bear }\end{array}$ & $\begin{array}{c}\text { Blubber } \\
\text { Blood }\end{array}$ & $\begin{array}{l}\text { BS } \\
\text { Sv }\end{array}$ & $\begin{array}{l}\text { Haglund et al., } 1997 \\
\text { Verreault et al., } 2005\end{array}$ \\
\hline
\end{tabular}

${ }^{\mathrm{a}} \mathrm{Al}$ - Alaska, CA - Canadian Arctic, EG - East Greenland, Sv - Svalbard, RA - Russian Arctic, BS - Baltic Sea 
studies on organohalogen contaminants in polar bear liver is limited. Legacy and emerging POPs, with the exception of halogenated phenoliccontaminants a nd total- $(\alpha)$ $\mathrm{HBCD}$, have been detected in polar bear liver. Noneof the legacy and/or emerging POPs have been detected in polar bear brain. Even though there are numerous studies on organohalogen contaminant levels in individual polar bear body compartments or blood, there has not been a study, to our knowledge, about the tissue composition of organohalogen contaminants in several body compartments of the same polar bears.

\subsubsection{Organohalogen related health concerns in polar bears}

In the Arctic environment polar bears are known to contain the highest levels on organohalogen contaminants (De Wit et al., 2004; Braune et al., 2005). In polar bears the organohalogen contaminants have been found to have endocrine disrupting properties. PCBs and OC pesticides in Svalbard polar bears showed a negative correlation on retinol (vitamin A) and thyroid hormone levels in the plasma (Skaare et al., 2001; Braathen et al., 2004). Thyroid hormones and vitamin A play important roles in growth and development. In female polar bears, blood levels of progesterone were positively correlated with $\sum$-PCB, while there was no correlation between $\sum$-PCB and $17 \beta$-estradiol and cortisol (Haave et al., 2003). A negative correlation was observed between PCB and OC pesticide levels and the plasma testosterone concentration (Oskam et al., 2003). In East Greenland polar bears, the levels of organohalogen contaminants were related to histologic changes in the liver (Sonne et al., 2005), and were thought to be a cofactor in the development of renal lesions (Sonne et al., 2006). 


\subsection{Thesis Objectives}

Information about the tissue-specific composition of legacy and emerging chlorinated and brominated contaminants and metabolites in the highly contaminated East Greenland polar bears is lacking. Whether ringed seal blubber is the source of all these POPs is unclear, aside from reports of legacy and some brominated contaminants, there is a dearth of information if the seal blubber is a source of metabolically formed contaminants. Trying to fill the knowledge gaps the following objectives are met:

1) To determine the identity and the tissue-specific composition of established (e.g., PCBs and OC pesticides) as well as emerging (flame retardants such as PBDEs, polybrominated biphenyls (PBBs) and hexabromocyclododecanes (HBCDs), and PCB and PBDE metabolites (degradation and/or natural products) POPs in fat, blood, brain and liver of male and female polar bears from East Greenland.

2) To assess the tissue-specific, bioaccumulation (including metabolism) and potential biomagnification of various and chlorinated and brominated contaminants from ringed seal blubber to polar bear tissues from East Greenland. 


\section{References}

Alaee, M., Arias, P., Sjödin, A., and Bergman, A., 2003. An overview of commercially used brominated flame retardants, their applications, their use patterns in different countries/regions and possible modes of release. Environment International 29, 683-689.

Andersen, M., Lie, E., Derocher, A.E., Belikov, S.E., Bernhoft, A., Boltunov, A.N., Garner, G.W., Skaare, J.U., and Wiig, Ø., 2001. Geographic variation of PCB congeners in polar bears (Ursus maritimus). Polar Biology 24, 231-238.

Ballschmiter, K., 1991. Global distribution of organic compounds.Journal of Environmental Science - Environmental Carcinogenic and Ecotoxicological Reviews, 9C, 1-46.

Bandiera, S.M., Torok, S.M., Lin, S., Ramsay, M.A., and Norstrom, R.J.,1 995. Catalytic and immunologic characterization of hepatic and lung cytochromes $\mathrm{P} 450$ in the Polar bear. Biochemical Pharmacology 49, 1135-1146.

Bandiera, S.M., Torok, S.M., Letcher, R.J., and Norstrom, R.J., 1997. Immunoquantitation of cytochromes P450 1A and P450 2B and comparison with chlorinated hydrocarbon levels in archived polar bear liver samples. Chemosphere 34, 1469-1479.

Bernhoft, A., Wiig, Ø., and Skaare, J.U., 1997. Organochlorines in polar bears (Ursus maritimus) at Svalbard. Environ.Pollut. 95, 159-175.

Birnbaum, L.S. and Staskal, D.F., 2004. Brominated flame retardants: cause for concern? Environmental Health Perspectives 112, 9-17.

Booij, K., Zegers, B.N., and Boon, J.P., 2002. Levels of some polychlorinated diphenyl ethers (PBDE) flame retardants along the Dutch coast as derived from their accumulation in SPMDs and blue mussels (Mytilus edulis). Chemosphere 46, 683688.

Boon, J.P., Lewis, W.E., Tjoen-A-Choy, M.R., Allchin, C.R., Law, R.J., De Boer, J., Ten Hallers-Tjabbes, C.C., Zegers, B.N., 2002. Levels of polybrominated diphenyl ether (PBDE) flame retardants in animals representing different trophic levels of North Sea food web. Environmental Science and Technology 36, 4025-4032.

Braathen, M., Derocher, A.E., Wiig, Ø., Sørmo, E.G., Lie, E., Skaare, J.U., and Jenssen, B.M., 2004. Relationship between PCBs and thyroid hormones and retinol in female and male polar bears. Environmental Health Perspectives 112, 826-833. 
Braune, B.M., Outridge, P.M., Fisk, A.T., Muir, D.C.G., Helm, P.A., Hobbs, K., Hoekstra, P.F., Kuzyk, Z.A., Kwan, M., Letcher, R.J., Lockhart, W.L., Norstrom, R.J., Stern, G.A., and Stirling, I., 2005. Persistent organic pollutants and mercury in marine biota of the Canadian Arctic: an overview of spatial and temporal trends. The Science of the Total Environment 351-352, 4-56.

Brouwer, A. and Van den Berg, K.J., 1986. Transthyretin (prealbumin) binding of PCBs, a model for the mechanism of interference with vitamine $A$ and thyroid hormone metabolism. Chemosphere 15, 1699-1706.

Brouwer, A., Blaner, W.S., Kukler, A., and Van den Berg, K.J., 1988. Study on the mechanism of interference of 3,4,3',4'-tetrachlorobiphenyl with the plasma retinol-binding proteins in rodents. Chemico-Biological Interactions 68, 203-217.

Carté, B. and Faulkner, D.J., 1981. Polybrominated diphenyl ethers from Dysodea herbacea, Dysidea chlorea and Phyllospongia foliascens. Tetrahedron 37, 23352339.

Chu, S., Covaci, A., Jacobs, W., Haraguchi, K., and Schepens, P., 2003. Distribution of methyl sulfone metabolites and polychlorinated biphenyls and p,p'-DDE in human tissues. Environmental Health Perspectives 111, 1222-1227.

Covaci, A., Gerecke, A.C., Law, R.J., Voorspoels, S., Kohler, M., Heeb, N.V., Leslie, H., Allchin, C.R., and De Boer, J., 2006. Hexabromocyclododecanes (HBCDs) in the environment and humans: a review. Environmental Science and Technology 40, 3679-3688.

Darnerud, P.O., Eriksen, G.S., Jóhannesson, T., Larsen, P.B., and Viluksela, M., 2001. Polybrominated diphenyl ethers: occurrence, dietary exposure, and toxicology. Environmental Health Perspectives 109, 49-68.

Darnerud, P.O., 2003. Toxic effects of brominated flame retardants in man and in wildlife. Environment International 29, 841-853.

De Boer, J.,, Wester, P.G., Klamer, H.J.C., Lewis, W.E., and Boon, J.P., 1998. Do flame retardants threaten ocean life? Nature 394, 28-29.

De Boer, J., De Boer, K., and Boon, J.P., 2000. Polybrominated biphenyls and diphenylethers. In Paasivirta, J. (Eds.). The Handbook of Environmental Chemistry. Berlin, Springer-Verlag, pp. 61-95.

De Voogt, P., Brinkman, U.A.Th., 1989. Production, properties and usage of pilychlorinated biphenyls. In: Kimbrough, R.D., Jensen, A.A. (Eds.), Halogenated biphenyls, Terphenyls, Naphtalenes, Dibenzodioxins and related products. Elsevier Science Publishers, Amsterdam, pp. 3-45.

De Wit, C.A., 2002. An overview of brominated flame retardants in the environment. Chemosphere 46, 583-624. 
De Wit, C.A., Alaee, M., and Muir, D.C.G., 2006. Levels and trends of brominated flame retardants in the Arctic. Chemosphere 64, 209-233.

Derocher, A.E., Andriashek, D., and Stirling, I.,1 993. Terrestrial foraging by polar bears during the ice-free period in Western Hudson Bay. Arctic 46, 251-254.

Derocher, A.E., Wiig, Ø. and Bangjord, G., 2000. Predation of Svalbard reindeer by polar bears. Polar Biology 23, 675-678.

Dietz, R., Riget, F.F., Sonne-Hansen, C., Letcher, R.J., Born, E.W., and Muir, D.C.G., 2004. Seasonal and temporal trends in polychlorinated biphenyls and organochlorine pesticides in East Greenland polar bears (Ursus maritimus), 19902001. The Science of the Total Environment 331, 107-124.

Dietz, R., Riget, F.F., Sonne, C., Muir, D.C.G., Backus, S.M., Born, E.W., Kirkegaard, M., and Letcher, R.J., 2006. Seasonal trends and bioaccumulation of polybrominated diphenyl ethers in free-ranging East Greenland polar bears (Ursus maritimus). Environmental Pollution, in perss.

Drouillard, K.G., Tomczak, M., Reitsma, S., and Haffner, G.D., 2006. A river-wide surveyof polychlorinated biphenyls (PCBs), polycyclic aromatic hydrocarbons (PAHs), and selected organochlorine pesticide residues in sediments of the Detroit River - 1999. Journal of Great Lakes Research 32, 209-226.

Eriksson, J., Green, N., Marsh, G., and Bergman, A., 2004. Photochemical decomposition of 15 polybrominated diphenyl ether congeners in methanol/water. Environmental Science and Technology 38, 3119-3125.

Fängström, B., Athanasiadou, M., Grandjean, P., Weihe, P., and Bergman, Å., 2002. Hydroxylated PCB metabolites and PCBs in serum from pregnant Faroese women. Environmental Health Perspectives 110, 895-899.

Fonnum, F., Mariussen, E., and Reistad, T., 2006. Molecular mechanisms involved in the toxic effects of polychlorinated biphenyls (PCBs) and brominated flame retardants (BFRs). Journal of Toxicology and Environmental Health, Part A 69, 21-35.

Fowles, J.R., Fairbrother, A., Baecher-Steppan, L., and Kerkvliet, N.I., 1994. Immunologic and endocrine effects of the flame retardant pentabromodiphenyl ether (DE-71) in C57BL/6 J mice. Toxicology 86, 49-61.

Fu, X., Schmitz, F.J., Govindan, M., Abbas, S.A., Hanson, K.M., Horton, P.A., Crews, P., Laney, M., and Schatzman, R.C., 1995. Enzyme inhibitors: new and known polybrominated phenols and diphenyl ethers from four indo-pacific Dysedea sponges. Journal of Natural Products 58, 1384-1391. 
Germer, S., Piersma, A.H., Van der Ven, L., Kamyschnikow, A., Frey, Y., Schmitz, H.J., and Schrenk, D., 2006. Subacute effects of the brominated flame retardants hexabromocyclododecane and tetrabromobisphenol A on hepatic cytochrome P450 levels in rats. Toxicology 218, 229-236.

George, S.G., 1994. Enzymology and molecular biology of phase II xenobioticconjugating enzymes in fish. In: Malins, D.C., Ostrander, G.K. (Eds.), Aquatic Toxicology; Molecular, Biochemical and Cellular perspectives. Lewis Publishers, CRC press, Boca Raton, pp. 37-85.

Gioia, R., Steinnes, E., Thomas, G.O., Mejier, S.N., and Jones, K.C., 2006. Persistent organic pollutants in European background air: derivation of temporal and latitudinal trends. Journal of Environmental Monitoring 8, 700-710.

Goksøyr, A., Förlin, L., 1992. The cytochrome P450 system in fish, aquatic toxicologyand environmental monitoring. Aquatic Toxicology 22, 287-312.

Guvenius, D.M., Hassanzadeh, P., Bergman, Å., and Norén, K., 2002. Metabolites of polychlorinated biphenyls in human liver and adipose tissue. Environmental Toxicology and Chemistry $21,2264-2269$.

Haave, M., Ropstad, E., Derocher, A.E., Lie, E., Dahl, E., Wiig, Ø., Skaare, J.U., and Jenssen, B.M., 2003. Polychlorinated biphenyls and reproductive hormones in female polar bears at Svalbard. Environmental Health Perspectives 111, 431-436.

Haglund, P.S., Zook, D.R., Buser, H.-R., and Hu, J., 1997. Identification and quantification of polybrominated diphenyl ethers and methoxy-polybrominated diphenyl ethers in Baltic biota. Environmental Science and Technology 31, 32813287 .

Hakk, H., Larsen, G., and Klasson-Wehler, E., 2002. Tissue distribution, excretion and metabolism of 2,2',4,4',5-pentabromodiphenyl ether (BDE-99) in male SpragueDawley rat. Xenobiotica 32, 369-382.

Hakk, H. and Letcher, R.J., 2003. Metabolism in the toxicoknetics and fate of brominated flame retardants - a view. Environment International 29, 801-828.

Hakk, H., Huwe, J.K., Low, M., Rutherford, D., and Larsen, G., 2006. Tissue distribution, excretion and metabolism of 2,2',4,4',6-pentabromodiphenyl ether (BDE-100) in male Sprague-Dawley rats. Xenobiotica 36, 79-94.

Hale, R.C., La Guardia, M.J., Harvey, E., Gaylor, M.O., and Mainor, T.M., 2006. Brominated flame retardant concentrations and trends in abiotic media. Chemosphere 64, 181-186. 
Hallgren, S. and Darnerud, P.O., 2002. Polybrominated diphenyl ethers (PBDEs), polychlorinated biphenyls (PCBs) and chlorinated paraffins (CPs) in rats - testing interactions and mechanisms for thyroid hormone effects. Toxicology 177, 227243.

Hamers, T., Kamstra, J.H., Sonneveld, E., Murk, A.J., Kester, M.H.A., Andersson, P.L., Legler, J., and Brouwer, A., 2006. In vitro profiling of the endocrine-disrupting potency of brominated flame retardants. Toxicological Sciences 92, 157-173.

Haraguchi, K., Kato, Y., Masuda, Y., and Kimura, R., 1997. Metabolism of 3,3',4,4'tetrachlorobiphenyl via sulphur-containing pathway in rat: liver-specific retention of methylsulphonyl metabolite. Xenobiotica 27, 831-842.

Hardy, M.L., 2002. Tho toxicology of the three commercial polybrominated diphenyl oxide (ether) flame retardants. Chemosphere 46, 757-777.

Hoekstra, P.F., Letcher, R.J., O'Hara, T.M., Backus, S.M., Solomon, K.R., and Muir, D.C.G., 2003. Hydroxylated and methylsulfone-containing metabolites of polychlorinated biphenyls in the plasma and blubber of Bowhead Whales (Balaena mysticetus). Environmental Toxicology and Chemistry 22, 2650-2658.

Hovander, L., Malmberg, T., Athanasiadou, M., Rahm, S., Bergman, Å., and KlassonWehler, E., 2002. Identification of hydroxylated PCB metabolites and other phenolic halogenated pollutants in human blood plasma. Archives of Environmental Contamination and Toxicology 42, 105-117.

Hung, H., Blanchard, P., Halsall, C.J., Bidleman, T.F., Stern, G.A., Fellin, P., Muir, D.C.G., Barrie, L.A., Jantunen, L.M., Helm, P.A., Ma, J., and Konoplev, A., 2005. Temporal and spatial variabilities of atmospheric polychlorinated biphenyls (PCBs), organochlorine (OC) pesticides and polycyclic aromatic hydrocarbons (PAHs) in the Canadian Arctic: results from a decade of monitoring. The Science of the Total Environment 342, 119-144.

Ikonomou, M.G., Rayne, S., and Addison, R.F., 2002. Exponential increases of the brominated flame retardants, polybrominated diphenyl ethers, in the Canadian Arctic from 1981 to 2000 . Environmental Science and Technology 36, 18861892.

Iverson, S.J., Stirling, I. and Lang, S.L.C., 2006. Spatial and temporal variation in the diets of polar bears across the Canadian Arctic: Indicators of changes in prey populations and environment. Symposia of the Zoological Society of London. In press.

Kannan, K., Yun, S.H., and Evans, T.J., 2005. Chlorinated, brominated, and perfluorinated contaminants in livers of polar bears from Alaska. Environmental Science and Technology 39, 9057-9063. 
Kato, Y., Haraguchi, K., Masuda, Y., Kimura, R., 1998. Reduction of thyroid hormone levels by methylsulfonyl metabolites of polychlorinated biphenyl congeners in rats. Archives of Toxicology 72, 541-544.

Kierkegaard, A., Bignert, A., Sellström, U., Olssen, M., Asplund, L., Jansson, B., and De Wit, C.A., 2004. Polybrominated diphenyl ethers (PBDEs) and their methoxylated derivatives in pike from Swedish waters with emphasis on temporal trends, 19672000. Environmental Pollution 130, 187-198.

Kucklick, J.R., Struntz, W.D.J., Becker, P.R., York, G.W., O'Hara, T.M., and Bohonowych, J.E., 2002. Persistent organochlorine pollutants in ringed seals and polar bears collected from northern Alaska. The Science of the Total Environment 287, 45-59.

Kurihara, H., Mitani, T., Kawabata, J., and Takahashi, K., 1999. Two new bromophenols from the red alga Odonthalia corymbifera. Journal of Natural Products 62, 882884.

Larsen, G.L., Bergman, Å., Klasson-Wehler, E., and Bass, N.M., 1991. A methylsulfonyl metabolite of a polychlorinated biphenyl can serve as a ligand for fatty acid binding protein in rat intestinal mucosa. Chemico-Biological Interactions 77, 315323.

Larsen, G.L., Huwe, J.K., Bergman, Å., Klasson-Wehler, E., and Hargis, P., 1992. Methylsulfonyl metabolites of xenobiotics can serve as ligands for fatty acid binding proteins in chicken liver and intestinal mucosa. Chemosphere 25, 11891194.

Legler, J. and Brouwer, A., 2003. Are brominated flame retardants endocrine disruptors? Environmental International 29, 879-885.

Letcher, R.J., Norstrom, R.J., and Bergman, Å., 1995. Geographical distribution and identification of methyl sulphone PCB and DDE metabolites in pooled polar bear (Ursus maritimus) adipose tissue from the western hemisphere Arctic and Subarctic regions. The Science of the Total Environment 160/161, 409-420.

Letcher, R.J., Norstrom, R.J., Lin, S., Ramsay, M.A., and Bandiera, S.M., 1996. Immunoquantitation and microsomal monooxygenase activities of hepatic cytochromes P4501A and chlorinated hydrocarbon contaminant levels in Polar bear (Ursus maritimus). Toxicology and Applied Pharmacology 137, 127-140.

Letcher, R.J., Norstrom, R.J., and Muir, D.C.G., 1998. Biotransformation versus bioaccumulation: sources of methyl sulfone PCB and 4,4'-DDE metabolites in the polar bear food chain. Environ.Sci.Technol. 32, 1656-1661. 
Letcher, R.J., Klasson-Whehler, E., and Bergman, §. ,2000. Methyl sulfone and hydroxylated metabolites of polychlorinated biphenyls. In Paasivirta, J. (Eds.). The Handbook of Environmental Chemistry. Berlin, Springer-Verlag, pp. 315359.

Lewis, D.F.V., Eddershaw, P.J., Dickins, M., Tarbit, M.H., and Goldfarb, P.S., 1998. Structural determinants of cytochrome P450 substrate specificity, binding affinity and catalytic rate. Chemico-Biological Interactions 115, 175-199.

Lilienthal, H., Hack, A., Roth-Härer, A., Wichert Grande, S., and Talsness, C.E., 2006. Effects of developmental exposure to 2,2',4,4',5,5'-Pentabromodiphenyl ether (PBDE-99) on sex steroids, sexual development, and sexually dimorphic behaviour in rats. Environmental Health Perspectives 114, 194-201.

Malmvärn, A., Marsh, G., Kautsky, L., Athanasiadou, M., Bergman, A., and Asplund, L., 2005. Hydroxylated and methoxylated brominated diphenyl ethers in the Red Algae Ceramium tenuicorne and Blue Mussels from the Baltic Sea. Environmental Science and Technology 39, 2990-2997.

Marsh, G., Athanasiadou, M., Bergman, A., and Asplund, L., 2004. Identifivation of hydroxylated and methoxylated polybrominated diphenyl ethers in Baltic Sea salmon (Salmo salar) blood. Environmental Science and Technology 38, 10-18.

Marsh, G., Athanasiadou, M., Athanassiadis, I., and Sandholm, A., 2006. Identification of hydroxylated metabolites in $2,2^{\prime}, 4,4^{\prime}$-tetrabromodiphenyl ether exposed rats. Chemosphere 63, 690-697.

McKinney, M.A., De Guise, S., Martineau, D., Beland, P., Lebeuf, M., and Letcher, R.J., 2006. Organohalogen contaminants and metabolites in beluga whale (Delphinapterus leucas) liver from two canadian populations. Environmental Toxicology and Chemistry $25,1246-1257$.

Meerts, I.A.T.M., Letcher, R.J., Hoving, S., Marsh, G., Bergman, A., Lemmen, J.G., Van der Burg, B., and Brouwer, A., 2001. In vitro estrogenicity of polybrominated diphenyl ethers, hydroxylated PBDEs, and polybrominated bisphenol A compounds. Environmental Health Perspectives 109, 399-407.

Meerts, I.A.T.M., Assink, Y., Cenijn, P.H., Van den Berg, J.H.J., Weijers, B.M., Bergman, A.., Koeman, J.H., and Brouwer, A., 2002. Placental transfer of a hydroxylated polychlorinated biphenyl and effects on fetal and maternal thyroid hormone homeostasis in the rat. Toxicological Sciences 68, 361-371.

Morris,S., 2006. Distribution and fate of HBCD and TBBPA brominated flame retardants in North Sea estuaries and aquatic food webs. Environmental Science and Technology 38, 5497-5504. 
Mörck, A., Hakk, H., Örn, U., and Klasson-Wehler, E., 2003. Decabromodiphenyl ether in the rat: absorption, distribution, metabolism, and excretion. Drug Metabolism and Disposition 31, 900-907.

Muir, D.C.G., Norstrom, R.J., and Simon, M., 1988. Organichlorine contaminants in arctic marine food chains: accumulation of specific polychlorinated biphenyls and chlordane-related compounds. Environmental Science and Technology 22, 1071 1079.

Muir, D.C.G. and Norstrom, R.J., 2000. Geographical differences and time trends of persistent organic pollutants in the Arctic. Toxicology Letters 112-113, 93-101.

Muir, D.C.G., Backus, S.M., Derocher, A.E., Dietz, R., Evans, T., Gabrielsen, G.W., Nagy, J., Norstrom, R.J., Sonne, C., Stirling, I., Taylor, M.K., and Letcher, R.J., 2006. Brominated flame retardants in polar bears (Ursus maritimus) from Alaska, the Canadian Arctic, Greenland, and Svalbard. Environmental Science and Technology 40, 449-455.

Nerbert, D.W., Nelson, D.R., Coon, M.J., Estabrook, R.W., Feyereisen, R., FujiiKuriyama, Y., Gonzolez, F.J., Guengerich, F.P., Gonsalus, I.C., Johnson, E.F., Loper, J.C., Sato, R., Waterman, M.R., Waxman, D.J., 1991. The P450 superfamily: update on new sequences, gene mapping and recommended nomenclature. DNA Cell Biology 10, 1-14.

Norstrom, R.J., Belikov, S.E., Born, E.W., Garner, G.W., Malone, B., Olpinski, S., Ramsay, M.A., Schliebe, S., Stirling, I., Stishov, M.S., Taylor, M.K., and Wiig,Ø., 1998. Chlorinated hydrocarbon contaminants in polar bears from Eastern Russia, North America, Greenlang, and Svalbard: biomonitoring of Artic pollution. Archives of Environmental Contamination and Toxicology 35, 354367.

Oskam, I.C., Ropstad E., and Dahl, E., 2003. Organochlorines affect the major androgenic hormone, testosterone, in male polar bears (Ursus maritimus) at Svalbard. Journal of Toxicology and Environmental Health, Part A 66, 21192139.

Oskam, I.C., Ropstad, E., Lie, E., Derocher, A.E., Wiig, Ø., Dahl, E., Larsen, S., and Skaare, J.U., 2004. Organochlorines affect the steroid hormone cortisol in freeranging polar bears (Ursus maritimus) at Svalbard, Norway. Journal of Toxicology and Environmental Health, Part A 67, 959-977.

Padmanabhan, J., Parthasarathi, R., Subramanian, V., and Chattaraj ,P.K., 2006. QSPR models for polychlorinated biphenyls: $n$-octanol/water partition coefficients. Bioorganic and Medicinal Chemisty 14, 1021-1028.

Remberger, M., Sternbeck ,J., Palm, A., Kaj, L., Strömberg, K., and Brorström-Lundén, E., 2004. The environmental occurence of hexabromocyclododecane in Sweden. Chemosphere 54, 9-21. 
Sacco, J.C. and James, M.O., 2004. Glucuronidation in the polar bear (Ursus maritimus). Marine Environmental Research 58, 475-479.

Sacco, J.C. and James, M.O., 2005. Sulfonation of environmental chemicals and their metabolites in the polar bear (Ursus maritimus). Drug Metabolism and Disposition 33, 1341-1348.

Sandala, G.M., Sonne-Hansen, C., Dietz, R., Muir, D.C.G., Valters, K., Bennett, E.R., Born, E.W., and Letcher, R.J., 2004. Hydroxylated and methyl sulfone PCB metabolites in adipose and whole blood of polar bear (Ursus maritimus) from East Greenland. The Science of the Total Environment 331, 125-141.

Sandau, C.D., Meerts, I.A.T.M., Letcher, R.J., McAlees, A.J., Chittim, B., Brouwer, A., and Norstrom, R.J., 2000. Identification of 4-hydroxyheptachlorostyrene in polar bear plasma and its binding affinity to transthyretin: a metabolite of octachlorostyrene. Environmental Science and Technology 34, 3871-3877.

Sanders, J.M., Chen, L.-J., Lebetkin, E.H., and Burka, L.T., 2006. Metabolism and disposition of 2,2',4,4'-tetrabromodiphenyl ether following administration of single or multiple doses to rats and mice. Xenobiotica 36, 103-117.

Schecter, A., Pavuk, M., Päpke, O., Ryan, J.J., Birnbaum, L.S., and Rosen, R., 2003. Polybrominated diphenyl ethers (PBDEs) in U.S. mothers' milk. Environmental Health Perspectives 111, 1723-1727.

Sijm, D.T.H.M., 2001. The 'B' inPBT: bioaccumulation. In: Lipnick, R.L., Hermens, J.L.M., Jones, K.C., Muir, D.C.G. (Eds.), Persistent, Bioaccumulative and Toxic chemicalsI fate and exposure. American Chemical Society, Washington, pp. 1326.

Skaare, J.U., Bernhoft, A., Wiig, Ø., Norum, K.R., Haug, E., Eide, D.M., and Derocher, A.E., 2001. Relationship between plasma levels of organochlorines, retinol and thyroid hormones from polar bears (Ursus maritimus) at Svalbard. Journal of Toxicology and Environmental Health, Part A 62, 227-241.

Smith, D.A., 1991. Species-differences in metabolism and pharmacokinetics - are we close to an understanding? Drug Metabolism Reviews 23, 355-373.

Smith, T. G., 1980. Polar bear predation of ringed and bearded seals in the land-fast sea ice habitat. Canadian Journal of Zoology 58, 2201-2209.

Smith, T. G. and Sjare, B., 1990. Predation of belugas and narwhals by polar bears in nearshore areas of the Canadian High Arctic. Arctic 43, 99-102. 
Sonne, C., Dietz, R., Leifsson, P.S., Born, E.W., Letcher, R.J., Kirkegaard, M., Muir, D.C.G., Riget, F.F., and Hyldstrup, L., 2005. Do organohalogen contaminants contribute to histopathology in liver from East Greenland polar bears (Ursus maritimus). Environmental Health Perspectives 113, 1569-1574.

Sonne, C., Dietz, R., Larsen, H.J.S., Loft, K.E., Kirkegaard, M., Letcher, R.J., Shahmiri, S., and Moller, P., 2006. Impairment of cellular immunity in West Greenland sledge dogs (Canis familiaria) dietary exposedto polluted minke whale (Balaenoptera acutorostrata) blubber. Environmental Science and Technology 40, 2056-2062.

Sørmo, E.G., Salmer, M.P., Jenssen, B.M., Hop, H., Bæk, K., Kovacs, K.M., Lydersen, C., Falk-Petersen, S., Gabrielsen, G.W., Lie, E., and Skaare, J.U., 2006. Biomagnification of brominated flame retardants in the polar bear food chain in Svalbard, Norway. Environmental Toxicology and Chemistry 25, 2502-2511.

Stapleton, H.M., Dodder, N.G., Kucklick, J.R., Reddy, C.M., Schantz, M.M., Becker, P.R., Gulland, F., Porter, B.J., and Wise, S.A., 2006. Determination of HBCD, PBDEs and MeO-PBDEs in California sea lions (Zalophus californianus) stranded between 1993 and 2003. Marine Pollution Bulletin 52, 522-531.

Stine, K.E., Brown, T.M., 1996. Principles of Toxicology. CRC Lewis Publishers, Boca Raton, pp. 21-36.

Stirling, I. and Archibald, W.R, 1977. Aspects of predation of seals by polar bears. Journal of the Fisheries Research Board of Canada 34, 126-129.

Tanabe, S., 1988. PCb problems in the future: foresight from current knowledge. Environmental Pollution 50, 5-28.

Teuten, E.L., Xu, L., and Reddy, C.M., 2005. Two abundant bioaccumulated halogenated compounds are natural products. Science 307, 917-920.

Thomann, R.V., 1989. Bioaccumulation model of organic chemical distribution in aquatic food chains. Environmental Science and Technology 23, 699-707.

Thuresson, K., Höglund, P., Hagmar, L., Sjödin, A., Bergman, §., and Jakobsson, K., 2006. Apparent half-lives of hepta- to decabrominated diphenyl ethers in human serum as determined in occupationally exposed workers. Environmental Health Perspectives 114, 176-181.

Tomy, G.T., Palace, V.P., Halldorson, T., Braekevelt, E., Danell, R., Wautier, K., Evans, B., Brinkworth, L., and Fisk, A.T., 2004. Bioaccumulation. biotransformation, and biochemical effects of brominated diphenyl ethers in juvenile lake trout (Salvelinus namaycush). Environmental Science and Technology 38, 1496-1504. 
Tomy, G.T., Halldorson, T., Danell, R., Law, K., Arsenault, G., Alaee, M., Macinnis, G., and Marvin, C.H., 2005. Refinements to the diastereoisomer-specific method for the analysis of hexabromocyclododecane. Rapid Communications in Mass Spectrometry 19, 2819-2826.

Ulbrich, B., Stahlmann, R., 2004. Developmenatl toxicity of polychlorinated biphenyls (PCBs): a systematic review of experimental data. Archives of Toxicology 78, 252-268.

Valters, K., Li, H., Alaee, M., D'Sa, I., Marsh, G., Bergman, Å., and Letcher, R.J., 2005. Polybrominated diphenyl ethers and hydroxylated and methoxylated brominated and chlorinated analogues in the plasma of fish from the Detroit River. Environmental Science and Technology 39, 5612-5619.

Verreault, J., Muir, D.C.G., Norstrom, R.J., Stirling, I., Fisk, A.T., Gabrielsen, G.W., Derocher, A.E., Evans, T.J., Dietz, R., Sonne, C., Sandala, G.M., Gebbink, W.A., Taylor, M.K., Nagy, J., and Letcher, R.J., 2005. Chlorinated hydrocarbon contaminants and metabolites in polar bear (Ursus maritimus) from Alaska, Canada, East Greenland, and Svalbard: 1996-2002. The Science of the Total Environment 351-352, 369-390.

Verreault, J., Letcher, R.J., Muir, D.C.G., Chu, S., Gebbink, W.A., and Gabrielsen, G.W., 2005. New organochlorine contaninants and metabolites in plasma and eggs of glaucous gulls (Larus hyperboreus) from the Norwegian Arctic. Environmental Toxicology and Chemistry 24, 2486-2499.

Verreault, J., Gabrielsen, G.W., Chu, S., Muir, D.C.G., Andersen, M., Hamaed, A., and Letcher, R.J., 2005. Flame retardants and methoxylated and hydroxylated polybrominated diphenyl ethers in two Norwegian Arctic top predators: glaucous gulls and polar bears. Environmental Science and Technology 39, 6021-6028.

Verreault, J., Norstrom, R.J., Ramsay, M.A., and Letcher, R.J., 2006. Composition of chlorinated hydrocarbon contaminants among major adipose depots of polar bears (Ursus maritimus) from the Canadian high Arctic. The Science of the Total Environment

Vorkamp, K., Christensen, J.H., and Riget, F.F., 2004. Polybrominated diphenyl ethers and organochlorine compounds in biota from the marine environment of East Greenland. The Science of the Total Environment 331, 143-155.

White, R.D., Hahn, M.E., Lockhart, W.L., and Stegeman, J.J., 1994. Catalytic and immunochemical characterization of hepatic microsomal cytochromes P450 in beluga whale (Delphinapterus leucas). Toxicol.Appl.Pharmacol. 126, 45-57.

Wiberg, K., Letcher, R.J., Sandau, C.D., Norstrom, R.J., Tysklind, M., and Bidleman, T.F., 2000. The enantioselective bioaccumulation of chiral chlordane and a-HCH contaminants in the polar bear food chain. Environmental Science and Technology 34, 2668-2674. 
Wolkers, H., Bavel, B.V., Derocher, A.E., Wiig, Ø., Kovacs, K.M., Lydersen, C., and Lindström, G., 2004. Congener-specific accumulation and food chain transfer of polybrominated diphenyl ethers in two arctic food chains. Environmental Science and Technology 38, 1667-1674.

Wolkers, J., Burkow, I.C., Lydersen, C., Dahle, S., Monshouwer, M., and Witkamp, R.F., 1998. Congener specific PCB and polychlorinated camphene (toxaphene) levels in Svalbard ringed seals (Phoca hispida) in relation to sex, age, condition and cytochrome P450 enzyme activity. The Science of the Total Environment 216, 111 . 


\section{CHAPTER 2}

\section{Material \& Methods}

\subsection{Sample Collection}

\subsubsection{Polar Bear Tissues}

Fat, brain and liver tissues and whole blood samples were sampled from 10 adult female and 10 adult male polar bears between July 1999 and January 2001 during the Inuit subsistence hunt in the Ittoqqortoormiit/Scoresby Sound area in central East Greenland between $69^{\circ} 00^{\prime} \mathrm{N}$ and $74^{\circ} 00^{\prime} \mathrm{N}$ (Figure 2.1.) (for information of the individuals see appendix 1, Dietz et al., 2004, Sandala et al., 2004; Verreault et al., 2005a). All tissues were taken $<12 \mathrm{~h}$ post mortem and stored in polyethylene bags. Whole blood samples were transferred to vacutainers containing the anticoagulant lithium heparin. All samples were frozen and kept at temperatures of -5 to $-20^{\circ} \mathrm{C}$ at the time of sampling, and stored at $-20^{\circ} \mathrm{C}$ when shipped from Scoresby Sound to Copenhagen, and then onto the NWRC (Environment Canada, Ottawa, ON, Canada) (Dietz et al., 2004; Sandala et al., 2004). All the polar bears were between 5.5 and 25 years old. The age of all the individuals was determined by counting annual growth layers in the cementum of an $\mathrm{I}_{3}$ tooth after decalcification, thin sectioning $(14 \mu \mathrm{m})$ and staining with toluidin blue (Dietz et al., 2004; Sandala et al., 2004). 


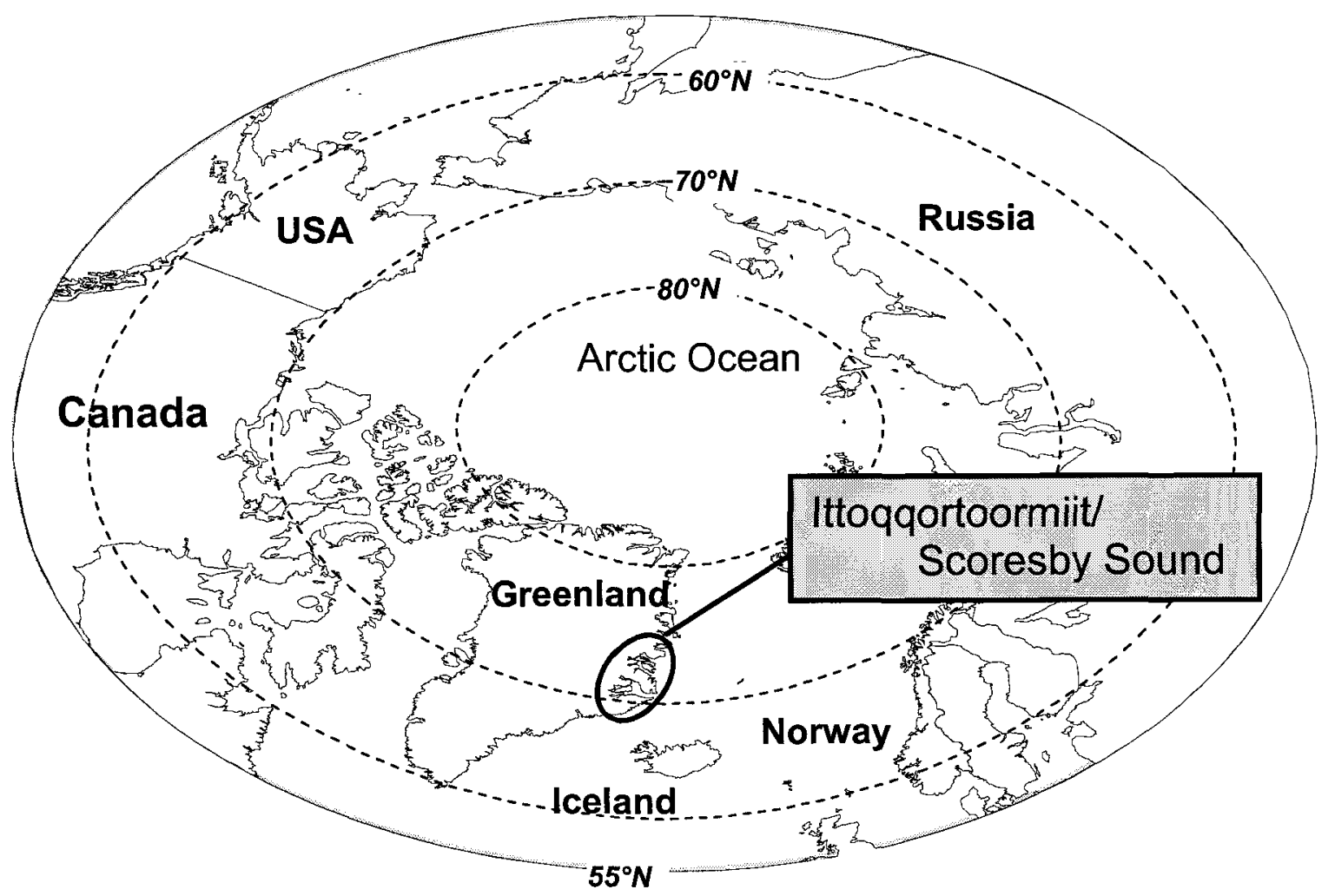

Figure 2.1. Sampling site in East Greenland for ringed seals and polar bears. 


\subsubsection{Ringed Seal Blubber}

Blubber tissues from 6 female and 9 male ringed seals were collected in 2002 in the Ittoqqortoormiit/Scoresby Sound area in central East Greenland (Figure 2.1.) (for information of the individuals see appendix 2). All tissues were taken $<12 \mathrm{~h}$ post mortem and stored in polyethylene bags. All samples were frozen and kept at temperatures of -5 to $-20^{\circ} \mathrm{C}$ at the time of sampling, and stored at $-20^{\circ} \mathrm{C}$ when shipped from Scoresby Sound to Copenhagen, and then onto the NWRC (Environment Canada, Ottawa, ON, Canada). All the ringed seals were between 1.5 and 11.5 years old.

\subsection{Chemicals and Standards}

The PCB, OC pesticide and 4-OH-HpCS standards were supplied by the Canadian Wildlife Service, Environment Canada (Ottawa, ON, Canada). PBDE, PBB, $\alpha-\mathrm{HBCD}$ and $\mathrm{MeO}-\mathrm{PCB}$ standards were purchased from Wellington Laboratories (Guelph, ON, Canada). $\mathrm{MeSO}_{2}-\mathrm{PCB}, \mathrm{MeSO}_{2}-\mathrm{DDE}$ and $\mathrm{MeO}-\mathrm{PBDE}$ standards were kindly provided by Åke Bergman and Göran Marsh (Stockholm University, Sweden). PCP was purchased from Accustandard (New Haven, CT, USA). The internal standards (IS) used were as follows: a mixture of $6{ }^{13} \mathrm{C}_{12}$-labeled PCB congeners (CB-28, $-52,-118,-153$, 180, and -194) for PCB analysis (Cambridge Isotope Laboratories, St.Leonard, QB, Canada), a mixture of $3{ }^{13} \mathrm{C}_{12}$-labeled OC pesticides $(1,2,4,5-\mathrm{TeClBz}, \mathrm{PnClBz}$ and $\mathrm{HCB})$ for OCs (Cambridge Isotope Laboratories, St.Leonard, QB, Canada), and BDE-30 and 71 for PBDEs, PBBs, total- $(\alpha)$-HBCD and MeO-PBDEs (Cambridge Isotope Laboratories, St.Leonard, QB, Canada). 3- $\mathrm{MeSO}_{2}-2-\mathrm{CH}_{3}-2^{\prime}, 3^{\prime}, 4^{\prime}, 5^{\prime}, 5^{\prime}-$ pentachlorobiphenyl was used as internal standard for $\mathrm{MeSO}_{2}-\mathrm{PCBs}$ and $\mathrm{MeSO}_{2}-\mathrm{DDE}$ 
( $\AA$.Bergman and G. Marsh), a mixture of $4{ }^{13} \mathrm{C}_{12}$-labeled $\mathrm{OH}-\mathrm{PCB}$ congeners (4'-OHCB120, 4'-OH-CB159, 4'-OH-CB172, 4'-OH-CB187) was used as internal standards for OH-PCBs, 4-OH-HpCS and PCP (Wellington Laboratories, Guelph, ON, Canada), 2'OH-BDE28 as internal standard for OH-PBDEs ( $\AA$. Bergman and G. Marsh). The PCB numbering is abbreviated using the notation of Ballschmiter et al. (1992), and PBDEs and PBBs are numbered analogously. PCB and PBDE metabolites are numbered by maintaining the same Ballschmitter et al. (1992) notation and denoting the position of the $\mathrm{OH}$ and/or $\mathrm{MeSO}_{2}$-fucntional group on the biphenyl or diphenyl ether backbone, respectively, as a prefix to the abbreviated name (Maervoet et al., 2004).

Chromatographic materials used for the analysis were as follows: Florisil (magnesium silicate, 60-100 mesh) purchased from Caledon Laboratories Ltd (Georgetown, ON, Canada), basic alumina (60-325 mesh) purchased from Fisher Scientific (Ottawa, ON, Canada) and silica gel (60-200 mesh, $150 \AA$ ) purchased from Sigma Aldrich (St Louis, MO, USA). All solvents and chemicals were at least of analytical-grade quality. NADPH regenerating system solutions $\mathrm{A}\left(\mathrm{NADP}^{+}\right.$, glucose-6-phosphate, $\left.\mathrm{MgCl}_{2}\right)$ and $\mathrm{B}$ (glucose-6-phosphate dehydrogenase) were purchased from Gentest (San Jose, CA, USA)

\subsection{Contaminant Extraction}

\subsubsection{Polar Bear Fat}

The extraction and clean-up of polar bear fat tissue for PCBs, OCs, PBDEs and $\mathrm{MeSO}_{2}-$ metabolites has been described in detail previously, where adjustments were made for the determination of halogenated phenolic metabolites and compounds (Chu et al., 2003; 
Dietz et al., 2004; Sandala et al., 2004; Verreault et al., 2005a; Muir et al., 2006). Briefly, approximately 0.5 grams of adipose tissue was homogenized with $\mathrm{Na}_{2} \mathrm{SO}_{4}$, spiked with the internal standards $(50 \mu$ l of each of the before mentioned internal standards with concentrations ranging from 100 to $500 \mathrm{pg} / \mu \mathrm{l}$ ) and extracted with $200 \mathrm{ml}$ DCM/n-hexanes $(1: 1)$. The extract was concentrated to $10 \mathrm{ml}$ and $10 \%$ was used for gravimetric lipid determination. Lipids were removed by gel permeation chromatography (GPC). The organic layer was concentrated to $\sim 0.5 \mathrm{ml}$ and transferred to a $\mathrm{KOH} / \mathrm{silica}$ column $(1.5 \mathrm{gr}, 33 \% \mathrm{KOH}$ deactivated by w/w) and eluted with $50 \mathrm{ml}$ $\mathrm{DCM} / \mathrm{n}$-hexanes $(1: 1)$. Subsequently the samples were concentrated and transferred to a Florisil column ( $8.0 \mathrm{~g}, 1.2 \% \mathrm{H}_{2} \mathrm{O}$ deactivated by w/w), and eluted with $75 \mathrm{ml}$ of DCM/nhexanes (1:1). This first fraction (F1) contained PCBs, OC pesticides, PBDEs, $\alpha$-HBCD, PBBs and MeO-PBDEs. A second fraction (F2), eluted from the Florisil column with 80 $\mathrm{ml} 7 \%$ methanol in $\mathrm{DCM}$, contained $\mathrm{MeSO}_{2}-\mathrm{PCBs}$ and $\mathrm{MeSO}_{2}$-DDE. F1 was concentrated and solvent exchanged to $1 \mathrm{ml}$ TMP in preparation for GC-MSD analysis. F2 was concentrated to $\sim 0.5 \mathrm{ml}$ and loaded on a basic alumina column $\left(3 \mathrm{~g}, 2.3 \% \mathrm{H}_{2} \mathrm{O}\right.$ deactivated by w/w) and eluted with $50 \mathrm{ml}$ DCM/n-hexanes (1:1), of which the first 10 $\mathrm{ml}$ was discarded. The extract was concentrated and solvent exchanged to $100 \mu 1 \mathrm{TMP}$ in preparation for GC-MSD analysis.

Recoveries for the higher chlorinated OH-PCB congeners of the internal standard mix were $\sim 10 \%$, while the recoveries of the lower chlorinated $\mathrm{OH}-\mathrm{PCB}$ congeners and $\mathrm{OH}-$ PBDE internal standard were $\sim 100 \%$ in the method described above. This was determined to be due to loss during GPC, and therefore an alternative approach for the 
cleanup for phenolic compounds was used. Besides size exclusion other mechanism as interactions with the glass column might have resulted in the poor elution through the GPC. In order to quantitatively isolate the halogenated phenolic compound (HPC) fraction, fat tissues were extracted as above. However, instead of GPC, liquid-liquid partitioning with concentrated $\mathrm{H}_{2} \mathrm{SO}_{4}$ was used to remove lipids from the extract. In the organic phase, the phenolic contaminants were isolated from neutral contaminants by $\mathrm{KOH}(1 \mathrm{M})$ partitioning, where the HPCs are deprotonated and thus partition into the aqueous phase. The aqueous HPC fraction was then acidified with concentrated $\mathrm{H}_{2} \mathrm{SO}_{4}$ to $\sim \mathrm{pH} 2$ to fully reprotonate the HPCs. The reprotonated HPCs were extracted from the acidified aqueous fraction with $\mathrm{MtBE} / \mathrm{n}$-hexanes (1:1), dried over $\mathrm{Na}_{2} \mathrm{SO}_{4}$, and derivatized to their methoxy analogues using diazomethane. The methoxylated HPCs were purified on a silica column $\left(3 \mathrm{~g}, 22 \% \mathrm{H}_{2} \mathrm{SO}_{4}\right.$ deactivated by w/w) and eluted with $50 \mathrm{ml} \mathrm{15 \%} \mathrm{DCM}$ in $\mathrm{n}$-hexanes. The extract was concentrated and solvent exchanged to $100 \mu \mathrm{l}$ TMP in preparation for GC-MSD analysis.

\subsubsection{Polar Bear Blood}

The extraction and clean-up of polar bear blood for all the contaminants has been described before (Sjodin et al., 2001; Sandala et al., 2004; Verreault et al., 2005b). Briefly, approximately 2 grams of whole blood was spiked with the internal standards (50 $\mu 1$ of each of the before mentioned internal standards with concentrations ranging from 100 to $500 \mathrm{pg} / \mu \mathrm{l})$, followed by the addition of $1 \mathrm{ml} 6 \mathrm{M} \mathrm{HCl}$ and $3 \mathrm{ml}$ 2-propanol. All contaminants were extracted with $\mathrm{MtBE} / \mathrm{n}$-hexanes $(1: 1)$, and by $\mathrm{KOH}$ partitioning the HPCs were separated from the neutral contaminants. The organic fraction containing 
neutral contaminants was concentrated and loaded on a Florisil column $\left(8.0 \mathrm{~g}, 1.2 \% \mathrm{H}_{2} \mathrm{O}\right.$ deactivated by w/w), and eluted with $75 \mathrm{ml}$ of DCM/n-hexanes (1:1) (F1) and $80 \mathrm{ml} 7 \%$ methanol in DCM (F2). F1, containing PCBs OC pesticides and brominated flame retardants, was concentrated and solvent exchanged to $1 \mathrm{ml}$ TMP in preparation for GCMSD analysis. F2, containing $\mathrm{MeSO}_{2}-\mathrm{PCBs} / \mathrm{DDE}$, was concentrated to $\sim 0.5 \mathrm{ml}$ and loaded on a basic alumina column $\left(3 \mathrm{~g}, 2.3 \% \mathrm{H}_{2} \mathrm{O}\right.$ deactivated by w/w) and eluted with $50 \mathrm{ml} \mathrm{DCM} / \mathrm{n}$-hexanes $(1: 1)$, of which the first $10 \mathrm{ml}$ was discarded. The extract was concentrated and solvent exchanged to $100 \mu \mathrm{T}$ TMP in preparation for GC-MSD analysis. The aqueous $\mathrm{KOH}$ fraction, containing all HPCs, was then acidified with concentrated $\mathrm{H}_{2} \mathrm{SO}_{4}$ to $\sim \mathrm{pH}$ 2. The reprotonated HPCs were extracted from the acidified aqueous fraction with $\mathrm{MtBE} / \mathrm{n}$-hexanes (1:1), dried over $\mathrm{Na}_{2} \mathrm{SO}_{4}$ and derivatized to their methoxy analogues using diazomethane. The methoxylated HPCs were purified on a silica column ( $3 \mathrm{~g}, 22 \% \mathrm{H}_{2} \mathrm{SO}_{4}$ deactivated by w/w) and eluted with $50 \mathrm{ml} \mathrm{15 \%} \mathrm{DCM}$ in $\mathrm{n}$-hexanes. The extract was concentrated and solvent exchanged to $100 \mu \mathrm{TMP}$ in preparation for GC-MSD analysis. The lipid content in blood was determinant by a sulfo-phosphovanilin reaction using olive oil-derived calibration curve ranging from 3 to $15 \mathrm{mg} / \mathrm{ml}$ (Sandau, 2000). The absorbance is measured at $540 \mathrm{~nm}$, the maximum absorbance.

\subsubsection{Polar Bear Brain}

Even though various methods are available in the literature for the analysis of several POP classes in brain, like PCBs, $\mathrm{OC}$ pesticides and $\mathrm{MeSO}_{2}-\mathrm{PCBs}$, none of these existing methods include the isolation of halogenated phenolic compounds (Dewailly et al., 1999; Metcalfe et al., 1999; Chu et al., 2003). Modifications were made to the Chu et al. (2003) 
method as it is virtually the only published method that assessed for environmental POPs other than PCBs and organochlorine pesticides, i.e., $\mathrm{MeSO}_{2}-\mathrm{PCBs}$, in brain tissue so that the HPCs were co-extracted and isolated. Briefly, approximately 2 grams of brain tissue were homogenized with $\mathrm{Na}_{2} \mathrm{SO}_{4}$, transferred into a pre-cleaned extraction thimble and spiked with the internal standards $(50 \mu l$ of each of the before mentioned internal standards with concentrations ranging from 100 to $500 \mathrm{pg} / \mu \mathrm{l}$ ) and Soxhlet extracted for 4 hours with $150 \mathrm{ml}$ acetone/n-hexanes (1:1). The extract was concentrated to $10 \mathrm{ml}$ and $10 \%$ was used for gravimetric lipid determination. Lipids were removed by liquid-liquid partitioning by adding $4 \mathrm{ml}$ of concentrated $\mathrm{H}_{2} \mathrm{SO}_{4}$, protonated $\mathrm{MeSO}_{2}-\mathrm{PCBs} /$-DDEs (in $\mathrm{H}_{2} \mathrm{SO}_{4}$ ) were separated from all other neutral contaminants (in organic phase). The aqueous acid phase was diluted with an equal-volume of $\mathrm{H}_{2} \mathrm{O}$ and the $\mathrm{MeSO}_{2}-\mathrm{PCBs} /-$ DDEs were extracted with $\mathrm{n}$-hexanes and eluted through a basic silica column ( $2 \mathrm{~g}, 33 \%$ $1 \mathrm{M} \mathrm{KOH}$ by w/w) with $20 \mathrm{ml} \mathrm{DCM}$. The neutral contaminants were separated from HPCs by aqueous $\mathrm{KOH}$ partitioning and combined with the $\mathrm{MeSO}_{2}-\mathrm{PCB} / \mathrm{DDE}$ fraction before being eluted through a Florisil column $\left(8.0 \mathrm{~g}, 1.2 \% \mathrm{H}_{2} \mathrm{O}\right.$ deactivated by w/w $)$. Fraction 1 was eluted with $75 \mathrm{ml}$ of DCM/n-hexanes (1:1) and fraction 2 with $80 \mathrm{ml} 7 \%$ methanol in DCM. F1 was concentrated and solvent exchanged to $1 \mathrm{ml}$ TMP in preparation for GC-MSD analysis. F2 was concentrated to $\sim 0.5 \mathrm{ml}$ and loaded on a basic alumina column (3 $\mathrm{g}, 2.3 \% \mathrm{H}_{2} \mathrm{O}$ deactivated by w/w) and eluted with $50 \mathrm{ml}$ DCM/n-hexanes $(1: 1)$, of which the first $10 \mathrm{ml}$ was discarded. The extract was concentrated and solvent exchanged to $100 \mu \mathrm{TMP}$ in preparation for GC-MSD analysis. The aqueous $\mathrm{KOH}$ fraction, containing all the desired HPCs, was then acidified with concentrated $\mathrm{H}_{2} \mathrm{SO}_{4}$ to $\sim \mathrm{pH}$ 2. As described for fat and whole blood samples, the 
reprotonated HPCs were extracted from the acidified fraction with $\mathrm{MtBE} / \mathrm{n}-\mathrm{hexanes}$ and derivatized to their methoxy analogues using diazomethane. The methoxylated HPCs were purified on a silica column $\left(3 \mathrm{~g}, 22 \% \mathrm{H}_{2} \mathrm{SO}_{4}\right.$ deactivated by w/w) and eluted with $50 \mathrm{ml} \mathrm{15 \%} \mathrm{DCM}$ in $\mathrm{n}$-hexanes. The extract was concentrated and solvent exchanged to $100 \mu 1$ TMP in preparation for GC-MSD analysis.

\subsubsection{Polar Bear Liver}

The extraction and clean-up of liver tissue for all the chlorinated and brominated contaminants that have been described has been described previously (Guvenius et al., 2001, 2002; Kannan et al., 2005; McKinney et al., 2006a). Briefly, approximately 0.5 gram of liver tissue was homogenized with $\mathrm{Na}_{2} \mathrm{SO}_{4}$, spiked with the internal standards (50 $\mu \mathrm{l}$ of each of the before mentioned internal standards with concentrations ranging from 100 to $500 \mathrm{pg} / \mu \mathrm{l})$ and extracted with $200 \mathrm{ml} \mathrm{DCM} /$ hexanes $(1: 1)$. The extract was concentrated to $10 \mathrm{ml}$ and $10 \%$ was used for gravimetric lipid determination. HPCs and neutrals were cleaned up and isolated in an identical fashion as described for polar bear fat, brain and whole blood samples in preparation for GC-MSD analysis.

\subsubsection{Ringed Seal Blubber}

The extraction of all contaminants from ringed seal blubber was the same as for polar bear fat. Briefly, approximately 1 gram of blubber tissue was homogenized with $\mathrm{Na}_{2} \mathrm{SO}_{4}$, spiked with the internal standards (50 $\mu \mathrm{l}$ of each of the before mentioned internal standards with concentrations ranging from 100 to $500 \mathrm{pg} / \mu \mathrm{l}$ ) and extracted with $200 \mathrm{ml}$ DCM/hexanes $(1: 1)$. The extract was concentrated to $10 \mathrm{ml}$ and $10 \%$ was used for 
gravimetric lipid determination. Lipids were removed by liquid-liquid partitioning by adding $4 \mathrm{ml}$ of concentrated $\mathrm{H}_{2} \mathrm{SO}_{4}$, and the protonated $\mathrm{MeSO}_{2}-\mathrm{PCBs} /-\mathrm{DDEs}$ (in $\mathrm{H}_{2} \mathrm{SO}_{4}$ ) were separated from all other contaminants (in organic phase). The acid phase was diluted with $\mathrm{H}_{2} \mathrm{O}(1: 1)$ and $\mathrm{MeSO}_{2}-\mathrm{PCBs} /-\mathrm{DDEs}$ were extracted with hexane and eluted through a basic silica column (2 g, 33\% $1 \mathrm{M} \mathrm{KOH}$ by w/w) with $20 \mathrm{ml} \mathrm{DCM}$. HPCs and neutrals were further cleaned up and isolated in an identical fashion as described for polar bear fat samples in preparation for GC-MSD analysis.

\subsection{In Vitro Microsomal Assay}

At the time of sample collection for logistical reasons in the field during sample collection it was not possible to obtain enzymatically viable liver tissue from East Greenland polar bears. As an alternative, hepatic microsomes were available from the NWRC sample archive, from the liver of a Canadian polar bear that had been collected between 1992 and 1994 near Resolute Bay, Northwest Territories and stored at $-80^{\circ} \mathrm{C}$. These hepatic microsomes had been prepared $\sim 10$ years ago for optimal preservation of oxidative cytochrome P450 monooxygenase catalytic activity (Letcher et al., 1996). These microsomes were then used to carry out in vitro PBDE (individual congeners) metabolic depletion assay. Procedures for oxidative metabolism in vitro PBDE metabolism assay have been described elsewhere (McKinney et al., 2006b). Briefly, the hepatic polar bear microsomes (1 $\mathrm{mg}$ total protein) were incubated in triplicate to individual BDE congeners (BDE-15, -47, -99, -100, -138, -153, -154, -183, -209, and $\alpha-$ $\mathrm{HBCD}$ ) at $10 \mu \mathrm{g} / \mathrm{ml}$, and all incubation contained CB-153 as internal/recovery standard and negative control. $\mathrm{CB}-153$ is a highly recalcitrant $\mathrm{CB}$ congener and has been shown 
previously not to be significantly depleted in the time frame of the assay when using seal or beluga whale hepatic microsomal assays (McKinney et al. 2006b; Li et al. 2003). The assay was initiated by the addition of NADPH regenerating system solutions (50 $\mu$ of Solution A and $10 \mu 1$ of Solution B) and the catalytic activity was terminated after 90 min by the addition of $0.5 \mathrm{M} \mathrm{NaOH}$. The 2'-OH-BDE28 congener was added as the IS for the brominated phenolic fraction prior to the extraction of the incubation medium with MtBE/n-hexanes. Phenolics were separated from neutrals by aqueous $\mathrm{KOH}$ partitioning. Each assay included BDE-15 as a positive control, which along with the negative, recovery control CB-153 was added at the very start of the microsomal incubation. Each set of assays included negative control assays $(n=3)$, where represented the extreme of no metabolic depletion, and where in place of the NADPH regenerating system solutions a buffer was added. The results are reported as the fraction of PBDE congener depleted (metabolized). For each incubation, the results for the parent PBDE congeners were first internal standard corrected (equation 1), the ratio ${ }_{\mathrm{CB} 153}$ for the samples (to which NADPH was added) was then compared to the ratio ${ }_{\mathrm{CB} 153}$ of the controls (to which NADPH was not added) (equation 2).

Ratio $_{\mathrm{CB} 153}=$ Peak area BDE-X / Peak area CB153 $\quad$ Equation 1

Fraction Remaining - Ratio $_{\mathrm{CB} 153}$ (sample) / Ratio ${ }_{\mathrm{CB} 153}$ Control Equation 2

\subsection{Determination of contaminants}

All of the GC-MSD analyses were preformed on an Agilent $6890 \mathrm{GC}$ equipped with and Agilent 5793 MSD detector and Agilent 7683 automated injector. Depending on the 
analyte or class, MSD was either in the electron impact (EI) or electron capture negative ionization (ECNI) mode.

\subsubsection{PCBs}

For the PCB analysis the GC was fitted with a fused silica DB-5 column $[(5 \%$ phenyl)methylpolysiloxane, $30 \mathrm{~m}, 0.25 \mathrm{~mm}$ ID, $0.25 \mu \mathrm{m}$ film thickness, J\&W Scientific]. The temperature program for PCBs was $100^{\circ} \mathrm{C}(3 \mathrm{~min}), 20^{\circ} \mathrm{C} / \mathrm{min}$ to $180^{\circ} \mathrm{C}, 2.5^{\circ} \mathrm{C} / \mathrm{min}$ to $300^{\circ} \mathrm{C}$ for optimal chromatographic resolution of PCB congener-specific determination. Helium was used as carrier gas, the injector temperature was $250^{\circ} \mathrm{C}$ and the transfer line temperature to the MS was set at $280^{\circ} \mathrm{C}$. The MS was set in electron impact (EI) ionization (positive) mode, with the ionization voltage set at $70 \mathrm{eV}$. The source and quadrupole temperature were $230^{\circ} \mathrm{C}$ and $150^{\circ} \mathrm{C}$, respectively. Selected ion monitoring (SIM) of $[\mathrm{M}]^{-}$and $[\mathrm{M}+2]^{-}$was applied where the ions chosen were selected for PCB congener homolog groups, which provided the necessary mass spectral resolution to compensate for most chromotographic co-elutions of some PCB congeners. An external standard quantification approach was used for PCB concentration determination. Response factors were used to calculate the PCB concentration in the samples. The extraction and analysis of PCBs, as well as OC pesticides, is a robust method generally resulting in high recoveries $(80-100 \%)$. Values are only recovery corrected when recoveries are $<80 \%$. The sum $(\Sigma)$ PCB concentration was composed quantifiable concentrations of 51 individual or coeluting congeners that were monitored: CB-28/31, $42,-44,-49,-52,-60,-64 / 71,-66 / 95,-70,-74,-84 / 101,-87,-97,-99,-105,-110,-118,-$ 
$128,-129 / 178,-138,-141,-146,-149,-151,-153,-156 / 171 / 202,-158,-170 / 190,-172,-$ $174,-177,-179,-180,-182 / 187,-183,-194,-195,-196 / 203,-200,-201$ and -206

\subsubsection{OC Pesticides}

For the $\mathrm{OC}$ pesticide analyses, the same chromatographic and mass spectral parameters were applied as for PCBs. SIM of $[\mathrm{M}]^{-}$and $[\mathrm{M}+2]^{-}$was applied where the ions chosen were selected for each of the nine OC pesticides that were monitored. An external standard quantification approach was used for OC concentration determination. However, for the current study, where OC pesticides were not the focus, the following "legacy" OC pesticides were quantified for comparative purposes. $\Sigma$-DDT concentration is the sum of $p, p^{\prime}-\mathrm{DDT}, p, p^{\prime}-\mathrm{DDD}$ and $p, p^{\prime}-\mathrm{DDE}$. $\Sigma$-CHL concentration is the sum of oxychlordane, trans-chlordane, cis-chlordane, trans-nonachlor, cis-nonachlor and heptachlor epoxide. These DDTs and CHLs have been shown elsewhere to be the dominant contributors to each pesticide class in the fat of circumpolar populations of polar bears (Norstrom et al., 1998; Verreault et al., 2005a).

\subsubsection{PBDEs, PBBs, total-( $\alpha)-H B C D$ and MeO-PBDEs}

For the PBDE, PBB, $\alpha-\mathrm{HBCD}$ and MeO-PBDE analysis the GC was fitted with a fused silica DB-5 column [(5\% phenyl)methylpolysiloxane, $15 \mathrm{~m}, 0.25 \mathrm{~mm}$ ID, $0.25 \mu \mathrm{m}$ film thickness, J\&W Scientific]. The temperature program was $90^{\circ} \mathrm{C}, 20^{\circ} \mathrm{C} / \mathrm{min}$ to $310^{\circ} \mathrm{C}(15$ min). Helium was used as carrier gas, the injector temperature was $250^{\circ} \mathrm{C}$ and the transfer line temperature to the MS was set at $280^{\circ} \mathrm{C}$. The MS was set in the electron capture negative ionization (ECNI) mode, with an ionization voltage of $70 \mathrm{eV}$. The 
source and quadrupole temperature were $150^{\circ} \mathrm{C}$ and $106^{\circ} \mathrm{C}$, respectively. Methane was used as collision gas. Using SIM, the isotopic bromine anions ( $\mathrm{m} / \mathrm{z} 79$ and 81$)$ were monitored. An internal standard quantification approach was used for the PBDE determination. The following congeners were monitored for in all tissue samples: BDE$17,28,-47,-66,-85,-99,-100,-138,-153,-154,-183,-190,-209$, BB-101, -153 (coelutes with BDE-154), $\alpha-\mathrm{HBCD}$ (i.e., accounts for the total of $\alpha-, \beta$ - and $\gamma-\mathrm{HBCD}$ isomers), 4'-MeO-BDE17, 6'-MeO-BDE17，2'-MeO-BDE28，4-MeO-BDE42，3-MeOBDE47，5-MeO-BDE47，6-MeO-BDE47，4'-MeO-BDE49，6'-MeO-BDE49，2'-MeOBDE68, 6-MeO-BDE85, 6-MeO-BDE90, 6-MeO-BDE99, 2-MeO-BDE123 and 6-MeOBDE137. The MeO-PBDE congeners are structures of possible metabolites of PBDEs or are naturally produced compounds.

\subsection{4. $\mathrm{MeSO}_{2}-\mathrm{PCBs}$ and $\mathrm{MeSO}_{2}$-DDE}

For the $\mathrm{MeSO}_{2}-\mathrm{PCBs}$ and $\mathrm{MeSO}_{2}-\mathrm{DDE}$ analysis the $\mathrm{GC}$ was fitted with a fused silica DB-5 column [(5\% phenyl)methylpolysiloxane, $30 \mathrm{~m}, 0.25 \mathrm{~mm} \mathrm{ID,} 0.25 \mu \mathrm{m}$ film thickness, J\&W Scientific]. The ramping program was $100^{\circ} \mathrm{C}(3 \mathrm{~min}), 20^{\circ} \mathrm{C} / \mathrm{min}$ to $220^{\circ} \mathrm{C}(1 \mathrm{~min}), 3^{\circ} \mathrm{C} / \mathrm{min}$ to $280^{\circ} \mathrm{C}(8 \mathrm{~min})$. Helium was used as carrier gas, the injector temperature was $280^{\circ} \mathrm{C}$ and the transfer line temperature to the MS was set at $280^{\circ} \mathrm{C}$. The MS was set in the ECNI mode with an ionization voltage of $70 \mathrm{eV}$. The source and quadrupole temperature were $180^{\circ} \mathrm{C}$ and $150^{\circ} \mathrm{C}$, respectively. Methane was used as collision gas. Using SIM the $[\mathrm{M}]^{-}$and $[\mathrm{M}+2]^{-}$ions were monitored for each chlorinated homolog group. An internal standard quantification approach was used for the $\mathrm{MeSO}_{2}-$ PCBs and $\mathrm{MeSO}_{2}-\mathrm{DDE}$ determination. The following congeners were monitored for all 
tissue samples: 3'- $\mathrm{MeSO}_{2}-\mathrm{CB} 49$, 4'- $^{\prime} \mathrm{MeSO}_{2}-\mathrm{CB} 49$, 3- $\mathrm{MeSO}_{2}-\mathrm{CB} 52$, 4- $\mathrm{MeSO}_{2}-\mathrm{CB} 52$, 3$\mathrm{MeSO}_{2}-\mathrm{CB} 64^{*}, 4-\mathrm{MeSO}_{2}-\mathrm{CB} 64,3-\mathrm{MeSO}_{2}-\mathrm{CB} 70,4-\mathrm{MeSO}_{2}-\mathrm{CB} 70,3^{\prime}-\mathrm{MeSO}_{2}-\mathrm{CB} 87^{*}, 4^{\prime}-$

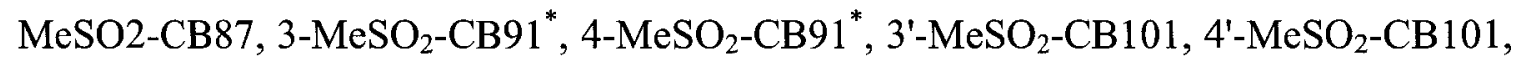
3- $\mathrm{MeSO}_{2}-\mathrm{CB} 110,4-\mathrm{MeSO} 2-\mathrm{CB} 110,3$ '- $\mathrm{MeSO}_{2}-\mathrm{CB} 132,4$ '- $\mathrm{MeSO}_{2}-\mathrm{CB} 132,3$ '- $\mathrm{MeSO}_{2}$ $\mathrm{CB}_{141}{ }^{*}, 4^{\prime}-\mathrm{MeSO}_{2}-\mathrm{CB} 141^{*}, 3-\mathrm{MeSO}_{2}-\mathrm{CB} 149,4-\mathrm{MeSO}_{2}-\mathrm{CB} 149^{*}, 3-\mathrm{MeSO}_{2}-\mathrm{CB} 174^{*}, 4-$ $\mathrm{MeSO}_{2}-\mathrm{CB} 174$ and 3-MeSO${ }_{2}-4,4^{\prime}-\mathrm{DDE}$ [There were no standards available for the marked (*) $\mathrm{MeSO}_{2}$-PCB congeners. Relative response factors (RRF) of other congeners with the same number of chlorination were used].

\subsubsection{OH-PCBs, 4-OH-HpCS and PCP}

For the $\mathrm{OH}-\mathrm{PCB}, 4-\mathrm{OH}-\mathrm{HpCS}$ and PCP (derivatized to MeO-analogues) analysis the GC was fitted with a fused silica DB-5 column [(5\% phenyl)methylpolysiloxane, $30 \mathrm{~m}, 0.25$ $\mathrm{mm}$ ID, $0.25 \mu \mathrm{m}$ film thickness, J\&W Scientific]. The ramping program was $80^{\circ} \mathrm{C}(1$ $\mathrm{min}), 10^{\circ} \mathrm{C} / \mathrm{min}$ to $250^{\circ} \mathrm{C}(5 \mathrm{~min}), 5^{\circ} \mathrm{C} / \mathrm{min}$ to $300^{\circ} \mathrm{C}(5 \mathrm{~min})$. Helium was used as carrier gas, the injector temperature was $280^{\circ} \mathrm{C}$ and the transfer line temperature to the MS was set at $300^{\circ} \mathrm{C}$. The MS was set in the ECNI mode with an ionization voltage of $70 \mathrm{eV}$. The source and quadrupole temperature were $200^{\circ} \mathrm{C}$ and $150^{\circ} \mathrm{C}$, respectively. Methane was used as collision gas. Using SIM the $[\mathrm{M}]^{-},[\mathrm{M}+2]^{-}$and $[\mathrm{M}-15]^{-}\left(\left[\mathrm{M}-\mathrm{CH}_{3}\right]^{-}\right)$ions of the MeO-containing derivatives of all $\mathrm{OH}-\mathrm{PCBs}$ were monitored. An internal standard quantification approach was used for the OH-PCB, 4-OH-HpCS and PCP determination. The MeO-PCB analogues of the following congeners were monitored for all the tissues: 4'-OH-CB79, 4-OH-CB97, 4'-OH-CB101/4-OH-CB134, 4-OH-CB107/4'-OH-CB108, 2'OH-CB114, 3-OH-CB118, 4'-OH-CB120, 4'-OH-CB127, 4'-OH-CB130, 3'-OH-CB138, 
4-OH-CB146, 4'-OH-CB159, 4-OH-CB162, 4-OH-CB163, 4'-OH-CB172, 4'-OH-CB177, 4-OH-CB178，3'-OH-CB180，3'-OH-CB182，3'-OH-CB183，3'-OH-CB184，4-OHCB187, 4-OH-CB193, 4'-OH-CB199, 4'-OH-CB200, 4'-OH-CB201, 4'-OH-CB202, 4,4'diOH-CB202, 3'-OH-CB203/4'-OH-CB198, 4'-OH-CB208, 4-OH-HpCS and PCP. The OH-PCB congeners are structures of possible metabolites of PCBs.

\subsubsection{OH-PBDEs and OH-PBBs}

For the OH-PBDE and OH-PBB analysis, the chromatographic and mass spectral parameters were the same as described for OH-PCBs. Using SIM, the isotopic bromine anions $(m / z 79$ and 81$)$ were monitored. An internal standard quantification approach was used for the OH-PBDE determination. The MeO-PBDE analogues of the following congeners were monitored for all tissue samples: 6'-OH-BDE17, 6'-OH-BDE17, 6'-OHBDE49, 2'-OH-BDE68, 6-OH-BDE47, 3-OH-BDE47, 5-OH-BDE47, 4'-OH-BDE49, 4OH-BDE42, 6-OH-BDE90, 6-OH-BDE99, 2-OH-BDE123, 6-OH-BDE85 and 6-OHBDE137. The OH-PBDE congeners are structures of possible metabolites of PBDEs or are naturally produced compounds

For the three OH-PBBs homologs that were identified (as described in section 3.2.2.3.), authentic analytical standards for any OH-PBB congeners are currently unavailable. Therefore, an alternate approach was applied in the quantitative determination of the tissue concentrations of the three $\mathrm{OH}-\mathrm{PBBs}$ congeners found in the present polar bears. An internal standard quantification approach, using 2'-OH-BDE28 as IS, and average relative response factors (RRF) from tri- and tetra-brominated $\mathrm{OH}-\mathrm{PBDEs}$ were used for 
the OH-PBB determination. Given that there were no commercially available, authentic standards for $\mathrm{OH}-\mathrm{PBB}$ congeners (i.e., their MeO-PBB analogues), the homolog structures of the apparent MeO-PBBs were confirmed using GC-high resolution MS (GC-HRMS). GC-HRMS analyses were preformed on a Hewlett-Packard 5890 Series GC connected to a VG Autospec, double focusing-magnetic sector mass spectrometer. The GC was equipped with a fused silica DB-5 column [(5\% phenyl)methylpolysiloxane, $30 \mathrm{~m}, 0.25 \mathrm{~mm} \mathrm{ID}, 0.25 \mu \mathrm{m}$ film thickness, J\&W Scientific], and the temperature ramping program started at $100^{\circ} \mathrm{C}(2 \mathrm{~min}), 20^{\circ} \mathrm{C} / \mathrm{min}$ to $180^{\circ} \mathrm{C}, 5^{\circ} \mathrm{C} / \mathrm{min}$ to $300^{\circ} \mathrm{C}(6 \mathrm{~min})$. Ionization was preformed by electron ionization (EI) with an electron voltage of $32 \mathrm{eV}$, and the source temperature was $280^{\circ} \mathrm{C}$. The mass spectrometer was operated at full scan mode (75 to $550 \mathrm{amu}$ ) at 1500 mass units resolution. The optimal mass spectrometer parameters were found using 3-OH-BDE47 standard since no $\mathrm{OH}-\mathrm{PBB}$ standards were available. By locking the exact mass of a perfluorokerosine (PFK) ion, the masses of the unknowns were determined with high accuracy.

\subsection{Quality Control and Assurance}

The analytes were identified by comparison of their relative chromatographic retention times to authentic reference standards. The mean recoveries were based on the internal standards, PCB recoveries were on average $93 \pm 7 \%, 106 \pm 17 \%, 55 \pm 25 \%$ and $108 \pm$ $22 \%$ for polar bear fat, blood, brain and liver, respectively, and $120 \pm 30 \%$ for ringed seal blubber. PBDE, PBB, total-( $\alpha)$-HBCD and MeO-PBDE recoveries were on average 100 $\pm 11 \%, 81 \pm 10 \%, 55 \pm 23 \%$ and $101 \pm 7 \%$ for polar bear fat, blood, brain and liver, respectively, and $80 \pm 16 \%$ for ringed seal blubber. Recoveries for $\mathrm{MeSO}_{2}-\mathrm{PCB}$ and 
$\mathrm{MeSO}_{2}$-DDE were $83 \pm 42 \%, 86 \pm 25 \%, 64 \pm 29 \%$ and $77 \pm 19 \%$ for polar bear fat, blood, brain and liver, respectively, and $111 \pm 38 \%$ for ringed seal blubber. OH-PCB, 4$\mathrm{OH}-\mathrm{HpCS}$ and PCP recoveries were $71 \pm 33 \%, 80 \pm 33 \%, 80 \pm 18 \%$ and $56 \pm 33 \%$ for polar bear fat, blood, brain and liver, respectively, and $44 \pm 8 \%$ for ringed seal blubber. OH-PBDE recoveries were $47 \pm 23 \%, 52 \pm 38 \%, 3 \pm 8 \%$ and $41 \pm 35$ for polar bear fat, blood, brain and liver, respectively, and $41 \pm 19 \%$ for ringed seal blubber. There was a drastic difference in the recoveryu of OH-PCBs and OH-PBDEs in the brain samples. A lower electronegativity of bromine relative to chlorine might have resulted in lower recoveries of the methylation of $\mathrm{OH}-\mathrm{PBDEs}$ relative to $\mathrm{OH}-\mathrm{PCBs}$. Unknown matrix effects in the brain samples might have resulted in the extreme low recoveries for $\mathrm{OH}-$ PBDEs.Recoveries for PCBs and OC pesticides were only recovery corrected when recovery was $<80 \%$. Recoveries for all other contaminants were inherently recovery corrected using the internal standard quantification method. Single point calibration was used; the range at which environmental levels were found was linear.

Quality assurance and quality control included laboratory method blanks, duplicate samples, matrix (IS) spikes, and calibration standard injections for each block of 5 samples to monitor changes in instrument sensitivity and analytical procedures that could affect the accuracy and precision of the quantitative analyte determinations. Method blank samples were analyzed to monitor for interferences and contamination and thus potentially result in an over-estimation of analyte concentrations. Concentrations in sample fractions were corrected only in cases where background contamination was present in the method blanks. Such situations only arose for a few BDE congeners. 
Traces of BDE-47, -99 and -100 were found systematically in the samples during the PBDE analysis and thus background subtracted. The background levels, between $5 \%$ and $<1 \%$ of the analyte in the sample, were subtracted per block of samples. The method limits of quantitation (MLOQs) for PCBs, OC pesticides and PBDEs were around 0.1 $\mathrm{ng} / \mathrm{g}$ wet wt for all the tissues, for $\mathrm{MeSO}_{2}$-PCBs, OH-PCB and OH-PBDE the MLOQs were around $0.05 \mathrm{ng} / \mathrm{g}$ wet wt for all the tissues. The MLOQs were based on a signal to noise (S/N) ratio of 10. Certified reference material (SRM 1945, pilot whale blubber homogenate) from the National Institute for Standards and Technology was used as a check for the accuracy and reproducibility of the analytical method. $\Sigma$-PCB and $\Sigma$-OC pesticides (CHLs and DDTs) were within 5\% and $8 \%$, respectively of the consensus values of SRM 1945 reported by Schantz et al. (1995), $\Sigma$-PBDE were within $13 \%$ of the values reported by Kucklick et al. (2004) on SRM 1945.

The EROD activity of the hepatic microsomes prepared from the livers from male polar bears collected from the Resolute Bay area in the Canadian Arctic, labelled $\mathbf{H}, \mathbf{J}$ and $\mathrm{L}$, used for the in vitro microsomal assay was between 1571 and $1680 \mathrm{pmol} / \mathrm{min} / \mathrm{mg}$ protein (Letcher et al., 1996). Even though the microsomes were continuous stored at $-80^{\circ} \mathrm{C}$ since 1996, reanalysis of the EROD activity of the microsomes from polar bear "K" in May 2006 showed that the EROD activity had only dropped by $40 \%$ from 1056 to 626 $\mathrm{pmol} / \mathrm{min} / \mathrm{mg}$ protein. EROD activity (CYP1A1 activity) is generally accepted as being representative of CYP isoenzyme catalytic activity in general. Despite this decrease in EROD activity, the microsomes remained appreciably viable and thus capable of an acceptable metabolic rate to be used in the in vitro PBDE metabolism microsomal assay. 
In studies with hepatic microsomes from western Hudson Bay beluga whales (Delphinapterus leucus) hepatic microsomes with lower EROD activity were capable of depletion several BDE congeners in the time frame of 90 min. incubation (McKinney et al., 2006b). Recovery of the CB-153 internal standard in all the in vitro assays was $>80 \%$.

\subsection{Data Analysis}

All statistical analyses of variance in organohalogen concentrations in fat, blood, brain and liver of male and female polar bears and blubber of male and female ringed seals were carried out using Statistica (Version 6.0, StatSoft, 2003; Tulsa, OK, USA). All hypotheses tested for analysis of variance in analyte concentrations between male and female polar bears and ringed seals used a one-way (factor) ANOVA, where the maximum probability of a type I error was set to $\alpha=0.05$. Therefore, statistical significance of variance was set at $p \leq 0.05$. Variables that did not approximate the normal distribution using the Shapiro-Wilk's $W$ test $(p<0.05)$ were $\log _{10}$ transformed to meet the assumptions of the statistical tests. Summary statistics for any analytes were computed only if at least $50 \%$ of the samples had concentrations above the MLOQ. Any sample concentrations within such a group below the MLOQ were assigned a random value between zero and half of the MLOQ. The sex of the polar bears was examined as possible variables affecting organohalogen concentrations in fat, blood, brain and liver of the bears. 


\section{Reference List}

Ballschmiter, K., Bacher, R., and Mennel, A., 1992. The determination of chlorinated biphenyls, chlorinated dibenzodioxins, and chlorinated dibenzofurans by GC-MS. Journal of High Resolution Chromatography 15, 260-270.

Chu, S., Covaci, A., Jacobs, W., Haraguchi, K., and Schepens, P., 2003. Distribution of methyl sulfone metabolites and polychlorinated biphenyls and p,p'-DDE in human tissues. Environmental Health Perspectives 111, 1222-1227.

Dewailly, E., Mulvad, G., Pedersen, H. S., Ayotte, P., Demers, A., Weber, J.-P., and Hansen, J. C., 1999. Concentration of organochlorines in human brain, liver, and adipose tissue autopsy samples from Greenland. Environmental Health Perspectives 107, 823-828.

Dietz, R., Riget, F. F., Sonne-Hansen, C., Letcher, R. J., Born, E. W., and Muir, D. C. G., 2004. Seasonal and temporal trends in polychlorinated biphenyls and organochlorine pesticides in East Greenland polar bears ( Ursus maritimus), 1990-2001. The Science of the Total Environment 331, 107-124.

Guvenius, D. M., Bergman, A., and Norén, K., 2001. Polybrominated diphenyl ethers in Swedish human liver and adipose tissue. Archives of Environmental Contamination and Toxicology 40, 564-570.

Guvenius, D. M., Hassanzadeh, P., Bergman, A., and Norén, K., 2002. Metabolites of polychlorinated biphenyls in human liver and adipose tissue. Environmental Toxicology and Chemistry 21, 2264-2269.

Kannan, K., Yun, S. H., and Evans, T. J., 2005. Chlorinated, brominated, and perfluorinated contaminants in livers of polar bears from Alaska. Environmental Science and Technology 39, 9057-9063.

Kucklick, J. R., Tuerk, K. J. S., Vander Pol, S. S., Schantz, M. M., and Wise, S. A., 2004. Polybrominated diphenyl ether congeners and toxaphene in selected marine standard reference materials. Analytical and Bioanalytical Chemistry 378, $1147-$ 1151 .

Letcher, R. J., Norstrom, R. J., Lin, S., Ramsay, M. A., and Bandiera, S. M., 1996. Immunoquantitation and microsomal monooxygenase activities of hepatic cytochromes P4501A and chlorinated hydrocarbon contaminant levels in Polar bear (Ursus maritimus). Toxicology and Applied Pharmacology 137, 127-140.

Li, H., Boon, J.P., Lewis, W.E., Van der Berg, M., Nyman, M. and Letcher, R.J., 2003. Hepatic microsomal cytochrome P450 enzyme activity in relation to in vitro metabolism/inhibition of polychlorinated biphenyls and testosterone in Baltic seal (Halichoerus Grypus). Environmental Toxicology and Chemistry 22, 636-644. 
McKinney, M. A., De Guise, S., Martineau, D., Beland, P., Lebeuf, M., and Letcher, R. J., 2006a. Organohalogen contaminants and metabolites in beluga whale (Delphinapterus leucas) liver from two canadian populations. Environmental Toxicology and Chemistry 25, 1246-1257.

McKinney, M. A., De Guise, S., Martineau, D., Béland, P., Arukwe, A., and Letcher, R. J., 2006b. Biotransformation of polybrominated diphenyl ethers and polychlorinated biphenyls in beluga whale (Delphinapterus leucas) and rat mammalian model using an in vitro hepatic microsomal assay. Aquatic Toxicology 77, 87-97.

Maervoet, J., Covaci, A., Schepens, P., Sandau, C. D., and Letcher, R. J., 2004. A reassessment of the nomenclature of polychlorinated biphenyl (PCB) metabolites. Environmental Health Perspectives 112, 1-4.

Metcalfe, C., Metcalfe, T., Ray, S., Paterson, G., and Koenig, B., 1999. Polychlorinated biphenyls and oranochlorine compounds in brain, liver and muscle of beluga whales (Delphinapterus leucas) from the Arctic and St. Lawrence estuary. Marine Environmental Research 47, 1-15.

Muir, D. C. G., Backus, S. M., Derocher, A. E., Dietz, R., Evans, T., Gabrielsen, G. W., Nagy, J., Norstrom, R. J., Sonne, C., Stirling, I., Taylor, M. K., and Letcher, R. J., 2006. Brominated flame retardants in polar bears (Ursus maritimus) from Alaska, the Canadian Arctic, Greenland, and Svalbard. Environmental Science and Technology 40, 449-455.

Sandala, G. M., Sonne-Hansen, C., Dietz, R., Muir, D. C. G., Valters, K., Bennett, E. R., Born, E. W., and Letcher, R. J., 2004. Hydroxylated and methyl sulfone PCB metabolites in adipose and whole blood of polar bear (Ursus maritimus) from East Greenland. The Science of the Total Environment 331, 125-141.

Schantz, M. M., Koster, B. J., Oakley, L. M., Schiller, S. B., and Wise, S. A., 1995. Certification of polychlorinated biphenyl congeners and chlorinated pesticides in a whale blubber standard reference material. Analytical Chemistry 67, 901-910.

Sjödin, A., Patterson Jr, D. G., and Bergman, $\AA ., 2001$. Brominated flame retardants in serum from US blood donors. Environmental Science and Technology 35, 38303833 .

Verreault, J., Muir, D. C. G., Norstrom, R. J., Stirling, I., Fisk, A. T., Gabrielsen, G. W., Derocher, A. E., Evans, T. J., Dietz, R., Sonne, C., Sandala, G. M., Gebbink, W. A., Taylor, M. K., Nagy, J., and Letcher, R. J., 2005a. Chlorinated hydrocarbon contaminants and metabolites in polar bear (Ursus maritimus) from Alaska, Canada, East Greenland, and Svalbard: 1996-2002. The Science of the Total Environment 351-352, 369-390. 
Verreault, J., Gabrielsen, G. W., Chu, S., Muir, D. C. G., Andersen, M., Hamaed, A., and Letcher, R. J., 2005b. Flame retardants and methoxylated and hydroxylated polybrominated diphenyl ethers in two Norwegian Arctic top predators: glaucous gulls and polar bears. Environmental Science and Technology 39, 6021-6028. 


\section{CHPATER 3}

\section{Tissue-Specific Composition of Brominated and Chlorinated Contaminants and Metabolically-Associated Compounds in Polar Bears (Ursus maritimus) from East Greenland ${ }^{\dagger}$}

\subsection{Introduction}

Polar bears (Ursus maritimus) from the East Greenland area of the Arctic are apical predators in the marine food web and have been documented to accumulate some of the highest levels of organochlorine (OC) contaminants, classified as persistent organic pollutants (POPs), in their tissues relative to animals from other circumpolar populations (Braune et al., 2005; Dietz et al., 2004; Verreault et al., 2005a). There are also a number of recent reports on previously unidentified and emerging classes of organohalogen contaminants and metabolically-associated products in polar bear tissues (mainly fat and/or blood) from Canadian, Alaskan, Greenland and Norwegian populations, such as polybrominated diphenyl ethers (PBDEs), methylsulfonyl-PCBs and methylsulfonylDDEs and hydroxy (OH) PCBs (Verreault et al., 2005a, b; Sandala et al., 2004; Sandau et al., 2000; Wolkers et al., 2004). Current understanding of organohalogen-induced biological effects in polar bears suggests that chronic exposure may compromise the normal function of, for example, endocrine, immune and reproductive systems, and perhaps also impact on population recruitment (Fisk et al., 2005; Kirkegaard et al., 2005; Sonne et al., 2006).

\footnotetext{
${ }^{\dagger}$ Gebbink et al. 2006. Environmental Toxicology and Chemistry. 
To our knowledge, studies examining the composition of many of these established (i.e., legacy) and emerging organohalogens among major lipid-bearing tissues and the body compartment blood is limited or lacking for polar bears from all Arctic populations. For polar bears, the only study that we are aware of that analyzed tissue composition differences was done by Verreault et al. (2006). This previous study examined the composition (i.e., concentrations and congener patterns) of legacy PCB congeners and OC pesticides in six major adipose depots collected from adult male polar bears in the vicinity of Resolute Bay, Canadian high Arctic.

The objective of this study is to determine the identity and the tissue-specific composition of established (e.g., PCBs and OC pesticides) as well as emerging [flame retardants such as PBDEs, polybrominated biphenyls (PBBs) and hexabromocyclododecanes (HBCDs), and PCB and PBDE metabolite, degradation and/or natural products] POPs in the fat, blood, brain and liver of male and female polar bears from East Greenland. These tissues are differentiated by the various functions they serve in the body, and thus the toxicokinetic influences that could potentially impact the fate of these organohalogens and the tissue-specific composition of the levels and congener patterns. Fat serves as the main storage for lipophilic compounds. Blood is the medium by which contaminants are transported through the body and by which they come into contact with various tissues. To protect the brain, a blood-brain barrier $(\mathrm{BBB})$ employs several mechanistic hindrances that may impact contaminant transport and subsequent deposition into the brain (Tilbury et al., 1997). The liver contains numerous xenobiotic-metabolizing enzyme systems at 
high activity levels, and is thus the major location for potential enzyme-mediated organohalogen biotransformation activity and protein binding (Letcher et al., 1996).

\subsection{Results \& Discussion}

POPs have been studied in polar bears from circumpolar populations and, in particular, have been studied in animals from the western hemisphere (Norstrom et al., 1998; Verreault et al., 2005a). Recently a wide range of chlorinated, brominated (e.g., PBDEs) (Muir et al., 2006) and fluorinated contaminants [e.g., polyfluoroalkyl compounds such as perfluorooctane sulfonate (PFOS)] (Houde et al., 2006; Smithwick et al., 2005) and their by-products (e.g., $\mathrm{MeSO}_{2-}$ and $\mathrm{OH}$-containing metabolites) (Sandau et al., 2000; Sandala et al., 2005; Verreault et al., 2005b) have been identified in polar bear fat or blood. However, there is a dearth of information on the tissue distribution or composition of legacy and emerging organohalogens in marine mammals in general, and in particular those from the Arctic including polar bears. Factors affecting the distribution and composition of contaminants are tissue-specific. These tissues contain unique biochemical processes that can selectively influence the toxicokinetics of a given contaminant. For example, in the liver, enzyme-mediated biotransformation which influences the fate and molecular form of a compound, or regarding the brain, there is a protective barrier that can limit passage of foreign chemicals into the inner regions of the brain. 


\subsubsection{Influence of sex}

The influence of sex on the concentrations of organohalogen classes and among tissues was examined. There were significant differences between males and females for some organohalogen classes (Table 3.1). In male polar bears, $\Sigma$-PCB levels in fat, brain and liver were significantly $(p<0.04)$ higher than female polar bears. Of the PCB metabolites, $\Sigma-\mathrm{MeSO}_{2}$-PCB was significantly $(p<0.04)$ higher in all the male tissues compared to the female tissues, whereas $\Sigma$-OH-PCB was only significantly $(p<0.01)$ higher in the male brain. Levels of 3-MeSO $2-p, p^{\prime}-\mathrm{DDE}$ in the male liver proved to be significantly higher than the female liver $(p<0.05)$ (Table 3.1). All the other POP classes (i.e., OC pesticides, PBDEs, HBCD, PBBs and their degradation products) showed no significant $(p>0.05)$ differences between males and females in all tissues, and therefore comparisons between the different tissues are made with males and females grouped as one (Table 3.2).

Since there was a significant difference in at least one tissue in levels of $\Sigma$-PCBs, $\Sigma$ $\mathrm{MeSO}_{2}-\mathrm{PCBs}, \Sigma-\mathrm{OH}-\mathrm{PCBs}$ and 3-MeSO $2-\mathrm{p}, \mathrm{p}^{\prime}-\mathrm{DDE}$ between male and female polar bears, subsequent comparisons of tissue composition are based on each sex as a separate sample set. The significantly lower levels of PCBs in the female tissues are due to a number of factors that include the ability of females to depurate contaminant loads via, for example, in utero and lactational transfer of PCBs from females to their offspring (Polischuk et al., 1995, 2002). A comparable in utero and lactational transfer depuration mechanism likely applies to lipophilic $\mathrm{MeSO}_{2}$-PCBs since these concentrations have been shown to co-vary with PCBs in polar bear fat and whole blood (Oehme et al., 1995; Sandala et al., 2004; Verreault et al., 2005a). 
Table 3.1. The mean ( \pm SE) of concentrations $(\mathrm{ng} / \mathrm{g})$ of classes of neutral and phenolic organohalogen compounds in female and male polar bear tissues from East Greenland.

\begin{tabular}{|c|c|c|c|c|c|c|c|c|c|}
\hline Sex & Analyte & $\begin{array}{c}\text { Fat } \\
\text { Mean }( \pm \mathrm{SE})\end{array}$ & $\begin{array}{c}\text { No. Samples } \\
>\text { MLOQ }\end{array}$ & $\begin{array}{c}\text { Blood } \\
\text { Mean }( \pm \mathrm{SE})\end{array}$ & $\begin{array}{c}\text { No. Samples } \\
\text { > MLOQ }\end{array}$ & $\begin{array}{c}\text { Brain } \\
\text { Mean }( \pm \mathrm{SE})\end{array}$ & $\begin{array}{c}\text { No. Samples } \\
>\text { MLOQ }\end{array}$ & $\begin{array}{c}\text { Liver } \\
\text { Mean }( \pm \mathrm{SE})\end{array}$ & $\begin{array}{c}\text { No. Samples } \\
\text { > MLOQ }\end{array}$ \\
\hline $\begin{array}{l}\text { Female } \\
(\mathrm{n}=10)\end{array}$ & $\begin{array}{l}\text { Lipid (\%) } \\
\sum-\mathrm{PCB}^{\mathrm{a}} \\
\Sigma-\mathrm{MeSO}_{2}-\mathrm{PCB}^{\mathrm{a}} \\
\Sigma-\mathrm{OH}_{-} \mathrm{PCB}^{\mathrm{b}} \\
\mathrm{MeSO}_{2}-\mathrm{DDE}^{\mathrm{a}}\end{array}$ & $\begin{aligned} 91 & \pm 7 \\
5,259 & \pm 729^{\mathrm{c}} \\
256 & \pm 61^{\mathrm{c}} \\
59 & \pm 15 \\
6.8 & \pm 1.7\end{aligned}$ & $\begin{array}{c}10 \\
10 \\
10 \\
8\end{array}$ & $\begin{array}{c}1.3 \pm 0.1 \\
2,247 \pm 426 \\
278 \pm 52^{\mathrm{c}} \\
827 \pm 112 \\
7.3 \pm 2.3\end{array}$ & $\begin{array}{c}10 \\
10 \\
10 \\
8\end{array}$ & $\begin{array}{c}20 \pm 1 \\
268 \pm 75^{\mathrm{c}} \\
40 \pm 11^{\mathrm{c}} \\
11 \pm 2^{\mathrm{c}} \\
\text { n.d. }\end{array}$ & $\begin{array}{c}10 \\
10 \\
10 \\
0\end{array}$ & $\begin{aligned} 11 & \pm 1 \\
22,844 & \pm 2,874^{\mathrm{c}} \\
1202 & \pm 341^{\mathrm{c}} \\
322 & \pm 56 \\
287 & \pm 51^{\mathrm{c}}\end{aligned}$ & $\begin{array}{l}10 \\
10 \\
10 \\
10\end{array}$ \\
\hline
\end{tabular}


Table 3.2. The mean ( \pm SE) of concentrations ( $\mathrm{ng} / \mathrm{g})$ of classes of neutral and phenolic organohalogen compounds in female and male polar bear tissues from East Greenland $(n=20)$.

\begin{tabular}{|c|c|c|c|c|c|c|c|c|}
\hline Analyte & $\begin{array}{c}\text { Fat } \\
\text { Mean ( } \pm \mathrm{SE}) \\
\end{array}$ & $\begin{array}{c}\text { No. Samples } \\
>\mathrm{MLOQ}\end{array}$ & $\begin{array}{c}\text { Blood } \\
\text { Mean }( \pm \text { SE })\end{array}$ & $\begin{array}{c}\text { No. Samples } \\
>\text { MLOQ }\end{array}$ & $\begin{array}{c}\text { Brain } \\
\text { Mean }( \pm \mathrm{SE})\end{array}$ & $\begin{array}{c}\text { No. Samples } \\
>\text { MLOQ }\end{array}$ & $\begin{array}{c}\text { Liver } \\
\text { Mean }( \pm \mathrm{SE})\end{array}$ & $\begin{array}{c}\text { No. Samples } \\
>\text { MLOQ }\end{array}$ \\
\hline Lipid (\%) & $90 \pm 4$ & & $1.3 \pm 0.1$ & & $21 \pm 1$ & & $11 \pm 1$ & \\
\hline$\Sigma-\mathrm{CHL}^{\mathrm{a}}$ & $1,502 \pm 132$ & 20 & $546 \pm 71$ & 20 & $69 \pm 25$ & 12 & $44,196 \pm 7011$ & 20 \\
\hline$\Sigma-$ DDT $^{\mathrm{a}}$ & $456 \pm 58$ & 20 & $1,775 \pm 559$ & 16 & $28 \pm 26$ & 2 & $2,453 \pm 648$ & 17 \\
\hline 4-OH-HpCS & $0.7 \pm 0.1$ & 20 & $9.7 \pm 1.1$ & 20 & $0.9 \pm 0.1$ & 20 & $7.6 \pm 1.4$ & 20 \\
\hline $\mathrm{PCP}^{\mathrm{b}}$ & $1.3 \pm 0.5$ & 18 & $0.10 \pm 0.02$ & 20 & $0.22 \pm 0.03$ & 17 & $3.6 \pm 0.6$ & 20 \\
\hline$\Sigma-\mathrm{PBDE}^{\mathrm{a}}$ & $97 \pm 19$ & 20 & $93 \pm 9$ & 20 & $14 \pm 2$ & 18 & $91,864 \pm 55,335$ & 20 \\
\hline Total- $(\alpha)-\mathrm{HBCD}^{\mathbf{a}}$ & $33 \pm 8$ & 13 & n.d. & 0 & n.d. & 0 & n.d. & 0 \\
\hline$\Sigma-P B B B^{a}$ & n.d. & 0 & n.d. & 0 & n.d. & 0 & $33 \pm 22$ & 3 \\
\hline$\Sigma-\mathrm{OH}-\mathrm{PBDE} \mathrm{E}^{\mathrm{b}}$ & $0.9 \pm 0.5$ & 13 & $2.9 \pm 1.0$ & 19 & n.d. & 0 & n.d. & 0 \\
\hline$\Sigma-\mathrm{MeO}-\mathrm{PBDE}{ }^{\mathrm{b}}$ & $4.3 \pm 1.7$ & 8 & $0.16 \pm 0.06$ & 7 & n.d. & 0 & $38 \pm 20$ & 17 \\
\hline
\end{tabular}

nd. - not detetced

${ }^{a} \mathrm{ng} / \mathrm{g}$ lipid wt, lipid associated

${ }^{\mathrm{b}} \mathrm{ng} / \mathrm{g}$ wet wt, protein associated 


\subsubsection{Tissue composition}

\subsubsection{PCBs, $\mathrm{MeSO}_{2}-\mathrm{PCBs}$ and $\mathrm{OH}-\mathrm{PCBs}$}

Polar bears from North American, Greenland and Svalbard populations have demonstrated a high capacity to metabolize PCBs as shown from the simplified PCB congener pattern, and the presence of high levels of both $\mathrm{OH}-\mathrm{PCB}$ and $\mathrm{MeSO}_{2}-\mathrm{PCB}$ metabolites (Braune et al., 2005; Sandala et al., 2004; Verreault et al., 2005a); however, no study has been undertaken on the distribution or composition of OH-PCBs and $\mathrm{MeSO}_{2}-\mathrm{PCBs}$, and in relation to $\mathrm{PCBs}$, in tissues other than fat and/or liver. More specifically, although present at very high levels in polar bear blood, no information exists on the accumulative potential of $\mathrm{OH}-\mathrm{PCBs}$ in any other polar bear tissue or via dietary uptake (Braune et al., 2005; Sandala et al., 2004).

\section{PCBs}

In the present study, both male and female polar bears possessed significantly $(p<0.003)$ higher L-PCB (lipid wt) concentrations in liver followed by fat, blood and brain (Table 3.1). $\Sigma$-PCB levels in all the tissues were significantly $(p<0.003)$ different from each other, with the exception of $\Sigma$-PCB in male fat and blood. Fat and blood levels on a lipid wt basis were comparable to earlier studies on the East Greenland population (Norstrom et al., 1998; Sandala et al., 2004; Dietz et al., 2004; Verreault et al., 2005a). PCBs have been detected in polar bear liver (Kannan et al., 2005) but there has been no direct comparison of PCB levels in polar bear fat and liver. Other marine mammals have shown slightly higher $\Sigma$-PCB levels in their liver compared to blubber (Wolkers et al., 2006). In polar bear brains, significantly $(p<0.0004)$ lower $\Sigma$-PCB concentrations were 
found relative to the other tissues for both males and females and, to our knowledge, there are no studies that report PCBs in polar bear brain, although PCBs have been detected in brain tissues of other marine mammals (Metcalfe et al., 1999; Tilbury et al., 1997). Despite factors such as the BBB and differences in lipid composition in the brain relative to other tissues, PCBs were present at appreciable levels in the present brain tissues. The BBB appears to be able to partly prevent PCBs from entering the brain as the lowest levels were found in the brain compared to the other tissues.

\section{$\mathrm{OH}-\mathrm{PCBS}$}

OH-PCBs have been shown to be PCB metabolites mediated by cytochrome P450 enzymes (Haraguchi et al., 2004; Letcher et al., 2000; Ohta et al., 2005). It has been suggested that $\mathrm{OH}-\mathrm{PCB}$ in polar bears are essentially of metabolic origin via PCB metabolism in the bear based on high levels of OH-PCBs in the blood (Sandala et al., 2004; Sandau et al., 2000) and greatly diminished levels of apparent PCB precursors in other tissues, such as fat, relative to the blubber of its major prey species, the ringed seal (Letcher et al., 1996, 1998; Muir et al., 1988). However, we presently have little or no knowledge on the dietary accumulation or the tissue-specific toxicokinetic behaviour of $\mathrm{OH}-\mathrm{PCB}$ in the polar bear. $\mathrm{OH}-\mathrm{PCB}$ have been postulated to accumulate in lipid-rich tissues based on their $\log K_{\mathrm{OW}}$ values $(5.9-7.2)$ and thus appreciable lipophilicity/hydrophobicity (Malmberg, 2004).

In the present study, $\Sigma$-OH-PCB concentrations in the blood were significantly $(p<0.001)$ higher than liver $>$ fat $>$ brain (wet wt basis) in both males and females (Table 3.1). All 
of the HPCs (chlorinated) determined did not significantly correlate with the percent lipid in any of the four tissues. Thus concentrations were not normalized to the fraction lipid as they are more protein-associated rather than lipid-associated (Figure 3.1, 3.2 and 3.3). Several OH-PCB congeners were shown to have a high affinity and competitively bind (relative to T4) to a major thyroid hormone transport protein in the blood, human transthyretin (TTR) (Malmberg, 2004). The present tissue composition data suggests that $\mathrm{OH}-\mathrm{PCB}$ associations with such proteins in the blood are important mechanisms by which $\mathrm{OH}-\mathrm{PCBs}$ are present as retained contaminants in polar bears in general. The relatively high levels of $\mathrm{OH}-\mathrm{PCB}$ s in the liver may be explained by the fact that the liver is the main source of TTR production and expression (Palha, 2002), combined with the fact that cytochrome $\mathrm{P} 450$ monooxygenase-mediated $\mathrm{OH}-\mathrm{PCB}$ formation from precursor PCB congeners appears to take place mainly in the liver. Besides accumulation in the brain tissue, residual blood might have also contributed to the OH-PCB levels found in the brains. The BBB night have a higher capacity towards preventing $\mathrm{OH}-\mathrm{PCBs}$ from entering the brain than the data suggests, some of the measured OH-PCBs could have been present in residual blood, not in the brain. $\Sigma-\mathrm{OH}-\mathrm{PCB}$ levels in fat were slightly higher compared to the levels in the brain indicating, that besides protein association, $\mathrm{OH}-\mathrm{PCB}$ are somewhat lipid associated despite the lack of lipid content to concentration correlations for these bears. The $\log K_{\mathrm{OW}}$ for a number of $\mathrm{OH}-\mathrm{PCB}$ congeners, like the major congeners 4-OH-CB146, 4-OH-CB187 and 4'-OH-CB199, have been modeled and shown to range from 5.9 to 7.2 , which indicates lipophilicity or hydrophobicity comparable to both PCBs and $\mathrm{MeSO}_{2}$-PCBs (Malmberg, 2004; Letcher et al., 2000; 

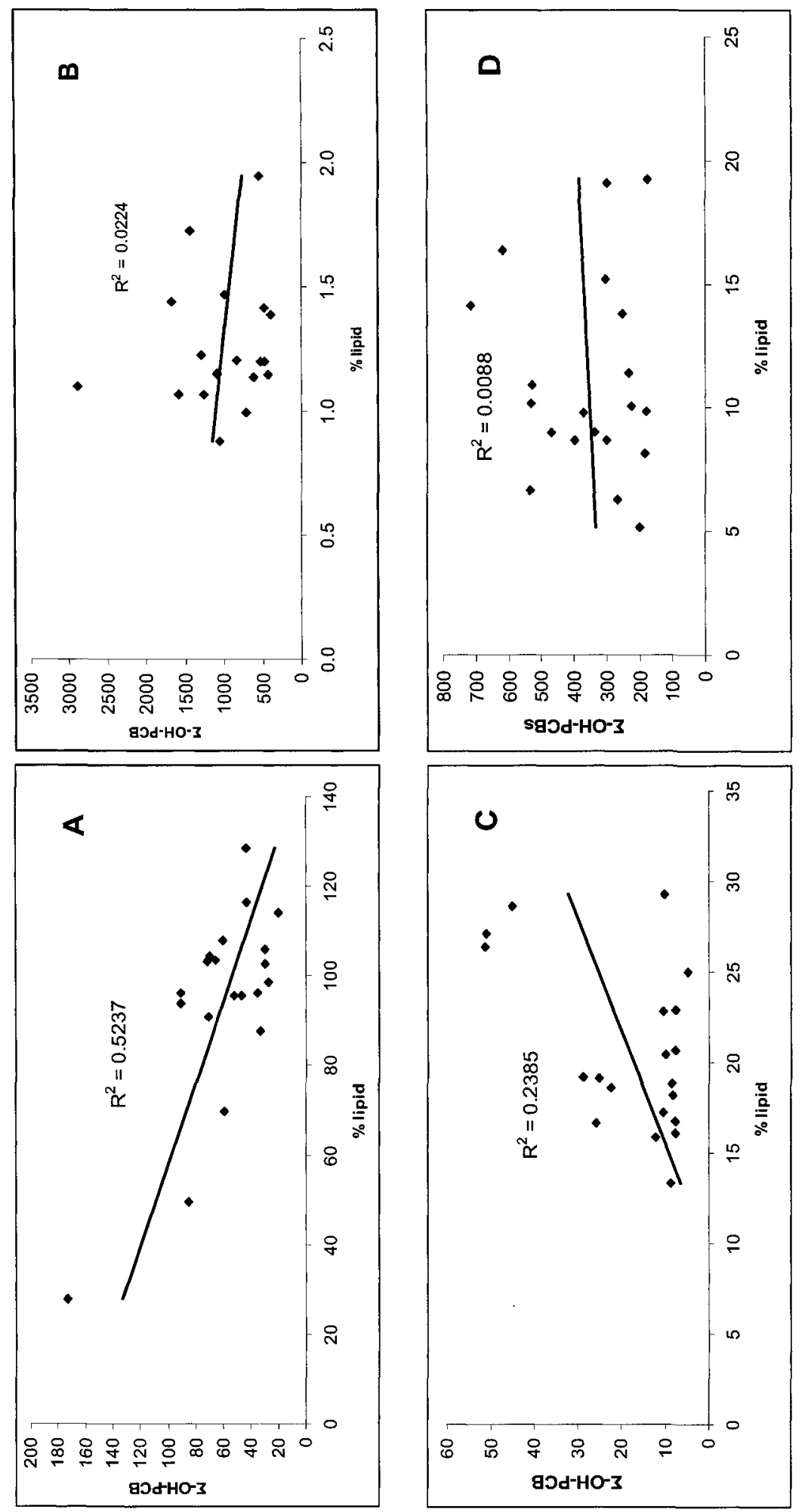

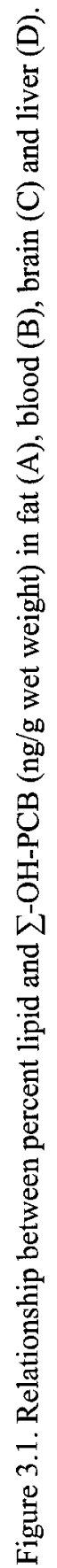



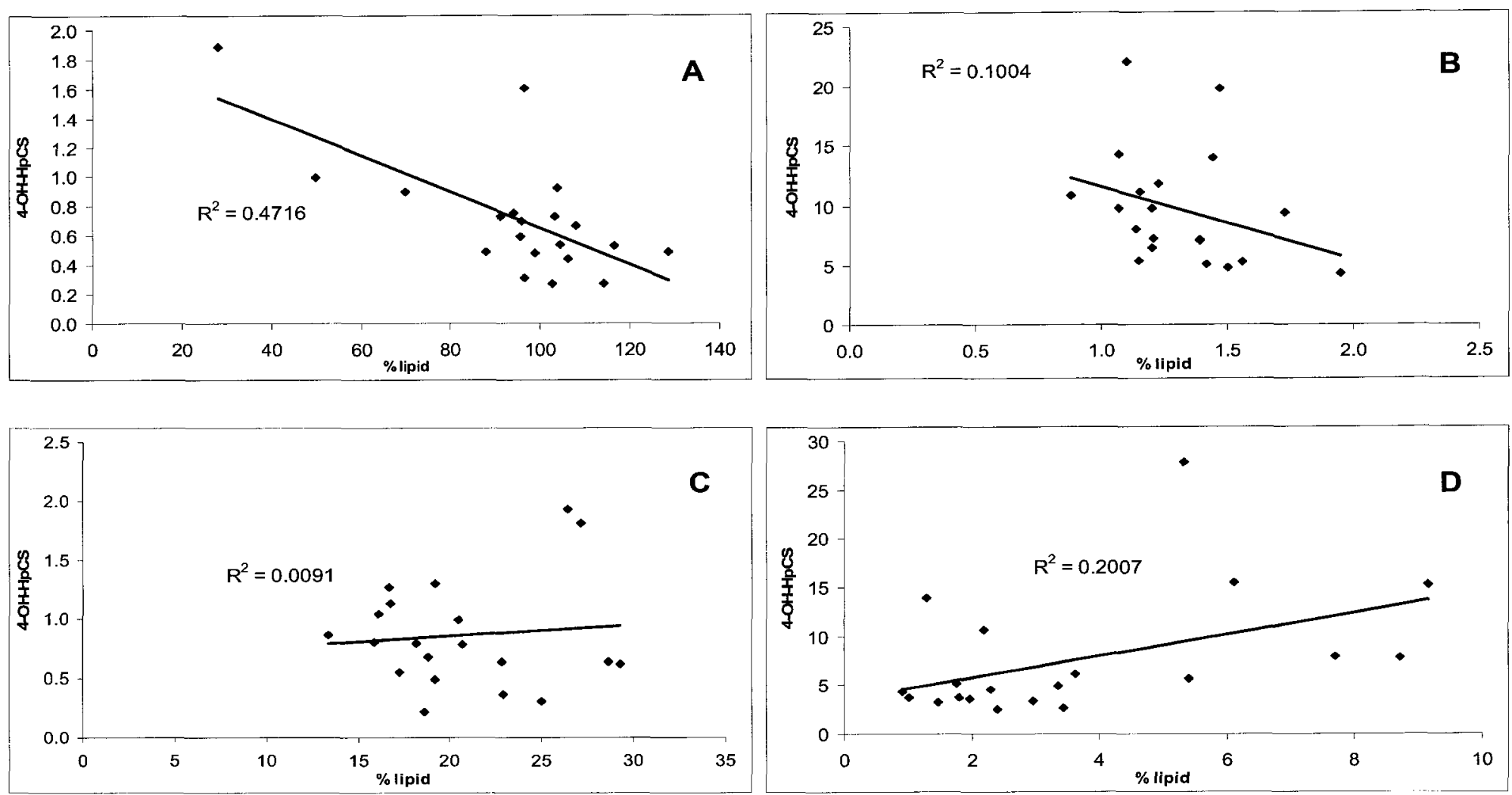

Figure 3.2. Relationship between percent lipid and 4-OH-HpCS (ng/g wet weight) in fat (A), blood (B), brain (C) and liver (D). 

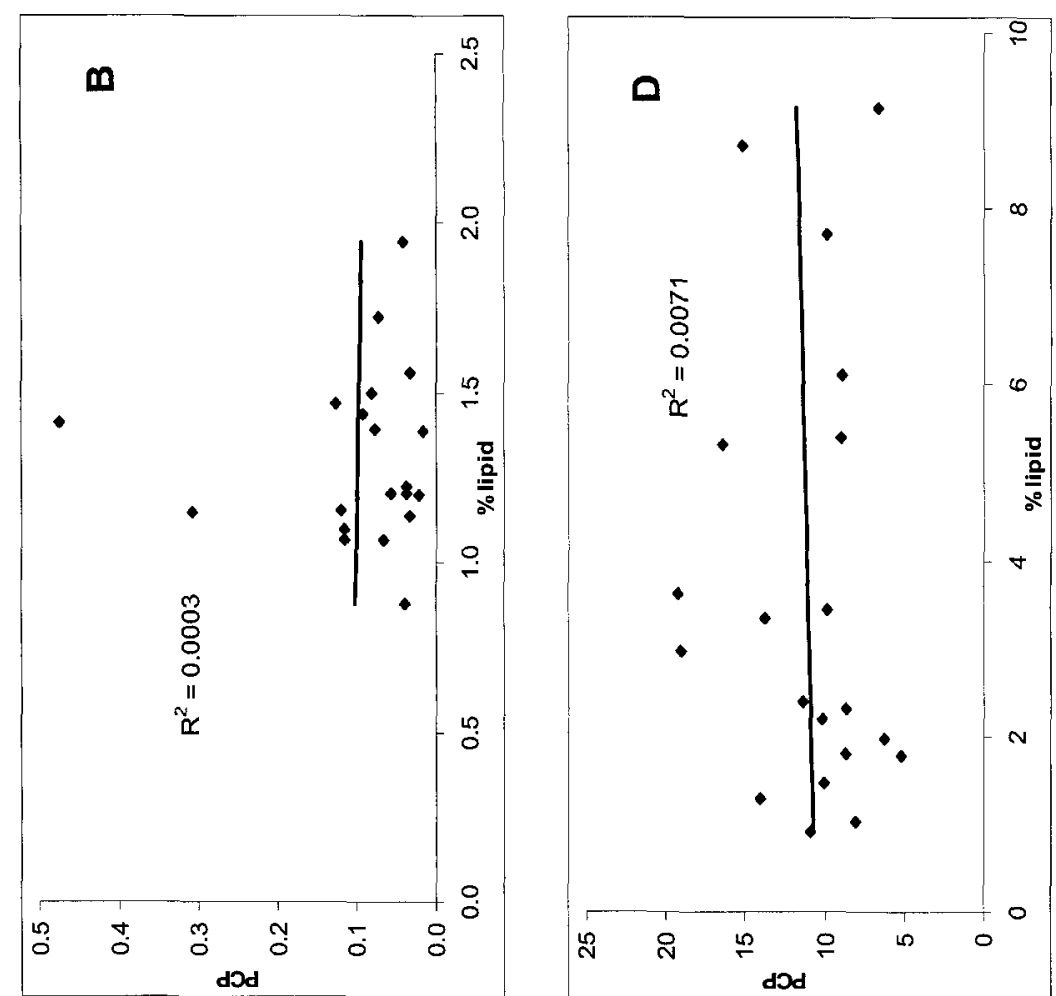

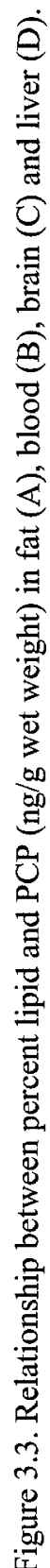


Padmanabhan et al., 2006). In the only other known study where the fat concentrations of OH-PCBs were determined, $\Sigma$-OH-PCB levels in human tissues were found to be 1-2 order of magnitude higher in liver compared to fat (Guvenius et al., 2002). For the present bears, the $\Sigma$-OH-PCB to $\Sigma$-PCB concentration ratio (which is independent of concentrations on a wet or lipid wt basis) corroborated the fact that OH-PCBs have a huge preference for retention in the blood relative to liver, brain or fat tissues (Table 3.3).

\section{$\mathrm{MeSO}_{2}-\mathrm{PCBS}$ and 3-MeSO $\mathrm{O}_{2}-\mathrm{p}, \mathrm{p}^{\prime}-\mathrm{DDE}$}

$\mathrm{MeSO}_{2}-\mathrm{PCBs}$ have $\log K_{\mathrm{OW}}$ values similar to $\mathrm{PCBs}$, ranging from 4 to 6.5 , which makes them highly lipophilic and are thus reported on a lipid wt basis (Letcher et al., 2000). The significantly $(p<0.009)$ highest $\Sigma-\mathrm{MeSO}_{2}-\mathrm{PCB}$ levels were found in the liver of male and female polar bears, followed by fat and blood concentrations. The significantly $(p<0.0002)$ lowest concentrations were found in the brain (Tables 3.1). Fat and blood concentrations of $\mathrm{MeSO}_{2}-\mathrm{PCBs}$ in East Greenland polar bears were comparable to earlier studies on this population (Letcher et al., 1995; Sandala et al., 2004). Looking at the $\Sigma$ $\mathrm{MeSO}_{2}-\mathrm{PCB}$ to $\Sigma$-PCB ratio, there was no significant difference regarding the distribution of the $\mathrm{MeSO}_{2}$ - $\mathrm{PCB}$ metabolite versus the precursor PCB among these tissues for male polar bears, and for female polar bears the $\Sigma$ - $\mathrm{MeSO}_{2}-\mathrm{PCB}$ to $\Sigma$-PCB ratio for fat and liver were significantly $(p<0.005)$ lower than the ratio in the blood and brain (Table 3.3). This indicates that $\mathrm{PCBs}$ and $\mathrm{MeSO}_{2}-\mathrm{PCBs}$ have similar properties (i.e., lipophilic and hydrophobic) and/or processes in polar bears that drive their metabolism/formation, physiological distribution, deposition, and fate for the tissues in question. 
Table 3.3. The mean $( \pm \mathrm{SE})$ of the ratios of the sum $(\Sigma)$ OH-PCB to $\Sigma-\mathrm{PCB}, \Sigma-\mathrm{MeSO}_{2}-\mathrm{PCB}$ to $\Sigma$-PCB and $\Sigma$-OH-PBDE to $\Sigma$-PBDE concentrations in fat, blood, brain and liver in East Greenland polar bears.

\begin{tabular}{|c|c|c|c|c|c|}
\hline Ratio & Sex & Fat & Blood & Brain & Liver \\
\hline$\Sigma-\mathrm{MeSO}_{2}-\mathrm{PCB} / \Sigma-\mathrm{PCB}^{\mathrm{a}}$ & $\begin{array}{l}\text { Female } \\
\text { Male }\end{array}$ & $\begin{array}{l}0.05 \pm 0.01 \\
0.09 \pm 0.01\end{array}$ & $\begin{array}{c}0.14 \pm 0.02 \\
0.018 \pm 0.02\end{array}$ & $\begin{array}{l}0.41 \pm 0.08 \\
0.26 \pm 0.15\end{array}$ & $\begin{array}{l}0.05 \pm 0.01 \\
0.08 \pm 0.02\end{array}$ \\
\hline$\Sigma-\mathrm{OH}-\mathrm{PCB} / \Sigma-\mathrm{PCB}^{\mathrm{b}}$ & $\begin{array}{l}\text { Female } \\
\text { Male }\end{array}$ & $\begin{array}{l}0.02 \pm 0.01 \\
0.01 \pm 0.01\end{array}$ & $\begin{array}{l}34 \pm 8 \\
31 \pm 9\end{array}$ & $\begin{array}{l}0.16 \pm 0.04 \\
0.18 \pm 0.05\end{array}$ & $\begin{array}{l}0.14 \pm 0.02 \\
0.12 \pm 0.02\end{array}$ \\
\hline$\Sigma-\mathrm{OH}-\mathrm{PBDE} / \Sigma-\mathrm{PBDE}^{\mathrm{b}}$ & $\mathrm{M} \& \mathrm{~F}$ & $0.02 \pm 0.04$ & $3.1 \pm 1.9$ & $-{ }^{c}$ & $-{ }^{c}$ \\
\hline
\end{tabular}


The 3- $\mathrm{MeSO}_{2}-p, p^{\prime}$-DDE has been characterized as a major metabolite of the $p, p^{\prime}-\mathrm{DDT}$ metabolite $p, p$ '-DDE (Letcher et al., 1998). The 3-MeSO $2-p, p$ '-DDE has previously been detected in fat, blood and liver samples of Canadian and East Greenland polar bears (Letcher et al., 1995, 1998; Sandala et al., 2004). For both male and female polar bears, the significantly $(p<0.0001)$ highest concentrations of 3-MeSO$-\mathrm{M}_{2}-p, p$ '-DDE were found in the liver compared to the fat and blood. The 3-MeSO $2-p, p$ '-DDE was not detected in the brain. The only significant $(p<0.02)$ difference in the $3-\mathrm{MeSO}_{2}-p, p$ '-DDE levels between males and females was in the liver (Table 3.1). As observed with $\mathrm{MeSO}_{2}-\mathrm{PCBs}$, the high selectivity towards the liver may be due to protein binding; $\mathrm{MeSO}_{2}$-containing chlorinated contaminants have been found to form a complex with fatty acid binding proteins (FABPs) in the liver (Larsen et al., 1991, 1992; Haraguchi et al., 1997; Letcher et al., 2000). In earlier studies, fat and blood concentrations were found in East Greenland polar bears (Sandala et al., 2004). The non-detectable levels of 3-MeSO $2-p, p$ 'DDE in the brain may be due to the overall lower body burden of this metabolite and other POPs, such as $\mathrm{MeSO}_{2} \mathrm{PCBs}$, which have been observed to have the lowest affinity to accumulate in the brain relative to other tissues.

To examine for any tissue-specific selectivity for PCB and PCB metabolite congeners, we investigated the congener patterns of these three classes. The PCB congener pattern for all tissues was similar in that only 6 congeners dominated the pattern: CB-99, -138 , 153, $-170 /-190,-180$ and -194 (Figure 3.4.A \& B). Those six congeners were all di-ortho chlorine substituted and had minimal or no chlorine-unsubstituted adjacent carbons, and thus had a low affinity to cytochrome P450 enzymes and, subsequently, a slower rate of 
metabolism (Letcher et al., 2000). This PCB congener pattern had been previously reported in polar bear (mainly fat) tissues (Muir et al., 1988; Letcher et al., 1998; Norstrom et al., 1998; Sandala et al., 2004; Kannan et al., 2005). The OH-PCB congener pattern was similar for all tissues and dominated by six congeners: 4-OH-CB146, 4-OHCB187, 4'-OH-CB202, 4-OH-CB193, 4'-OH-CB199 and 4,4'-diOH-CB202 (Figure 3.5.A \& B). Comparable congener patterns and blood concentrations were found in an earlier study on East Greenland polar bears (Sandala et al., 2004). With the exemption of the liver, the $\mathrm{MeSO}_{2}$-PCB congener pattern was similar for all the tissues, and dominated by the congeners: 4'- $\mathrm{MeSO}_{2}-\mathrm{CB} 87,3$ '- $\mathrm{MeSO}_{2}-\mathrm{CB} 101$ and 4'- $\mathrm{MeSO}_{2}-\mathrm{CB} 101$ (Figure 3.6.A \& B).

The PCB and PCB metabolite congener patterns were overall similar for the four tissues, with the exception of the $\mathrm{MeSO}_{2}$-PCB congener pattern in the liver, and thus there was no tissue-specific selectivity with respect to the $\mathrm{PCB}, \mathrm{OH}-\mathrm{PCB}$ or $\mathrm{MeSO}_{2}-\mathrm{PCB}$ congener patterns. This congener specific difference in the liver may be related to $\mathrm{MeSO}_{2}-\mathrm{PCBs}$ congeners binding to the $\mathrm{FABP}$, such as the 4,4'-bisMeSO${ }_{2}-\mathrm{CB} 52$ congener which has been found to bind to FABP in rat and chicken liver (Larsen et al., 1991, 1992; Haraguchi et al., 1997; Letcher et al., 2000). Factors such as lipid partitioning $\left(\log K_{O W}\right)$, protein binding, and the $\mathrm{BBB}$ did not influence the PCB and PCB metabolite congener patterns in the present bear tissues. 

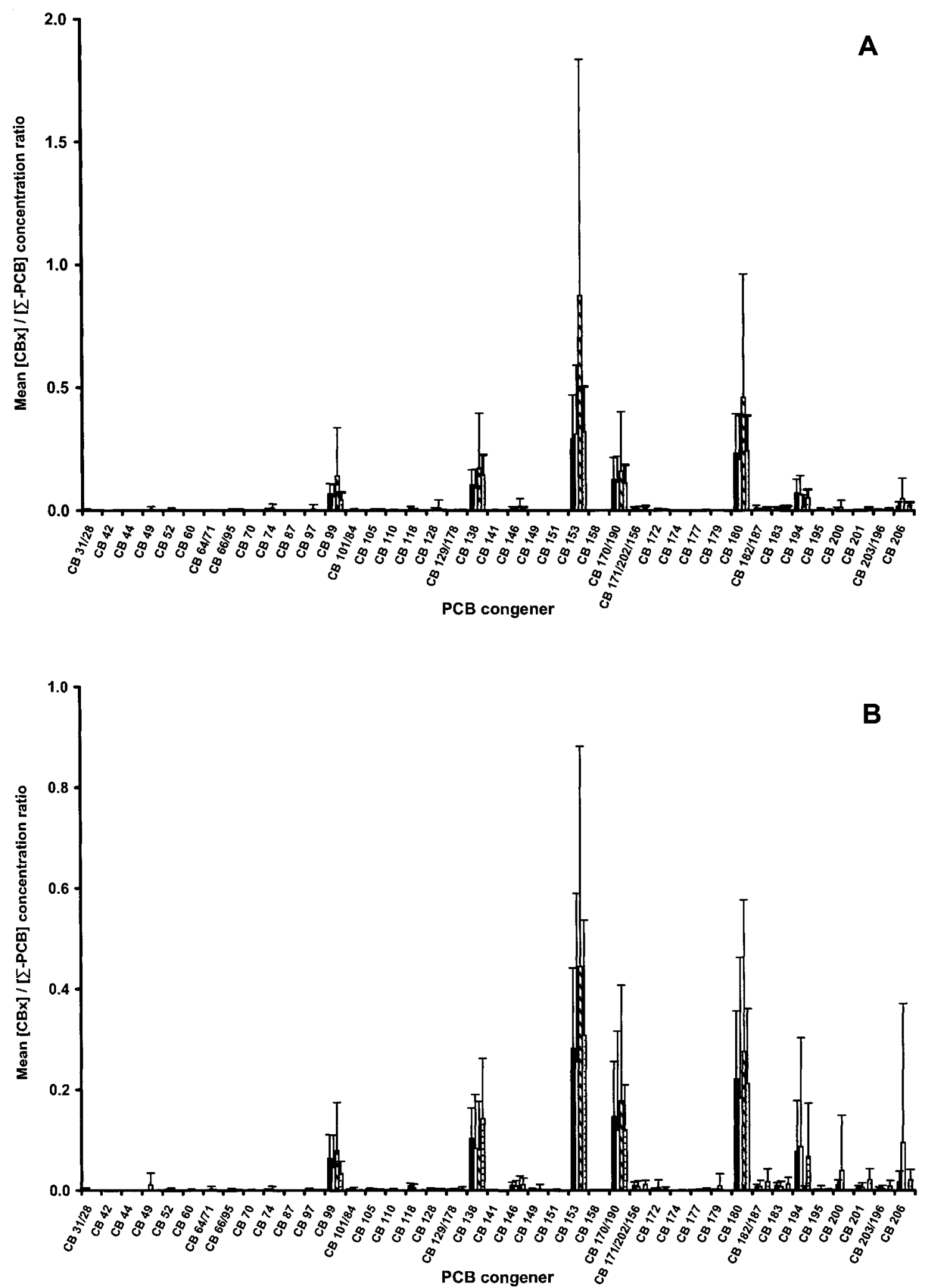

Figure 3.4. The mean ratios of the concentrations of individual PCB congeners to $\Sigma$-PCB in fat (black bars), blood (white bars), brain (stripped bars) and liver (dotted bars) in female (A) and male (B) polar bears from East Greenland. The error bars indicate the \pm SD of the mean ratios. 

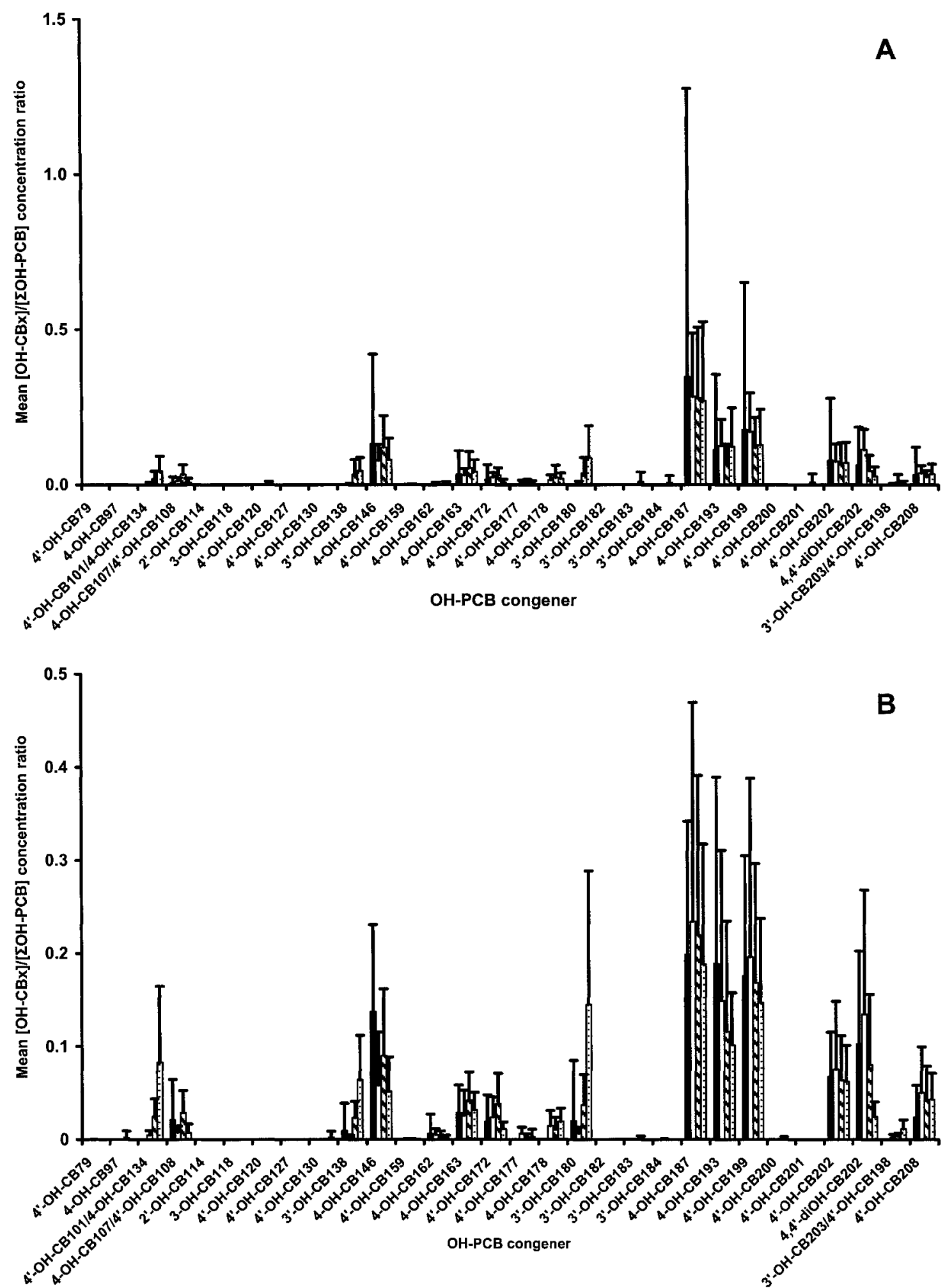

Figure 3.5. The mean ratios of the concentrations of individual OH-PCB congeners to $\Sigma$-OH-PCB in fat (black bars), blood (white bars), brain (stripped bars) and liver (dotted bars) in female (A) and male (B) polar bears from East Greenland. The error bars indicate the \pm SD of the mean ratios. 

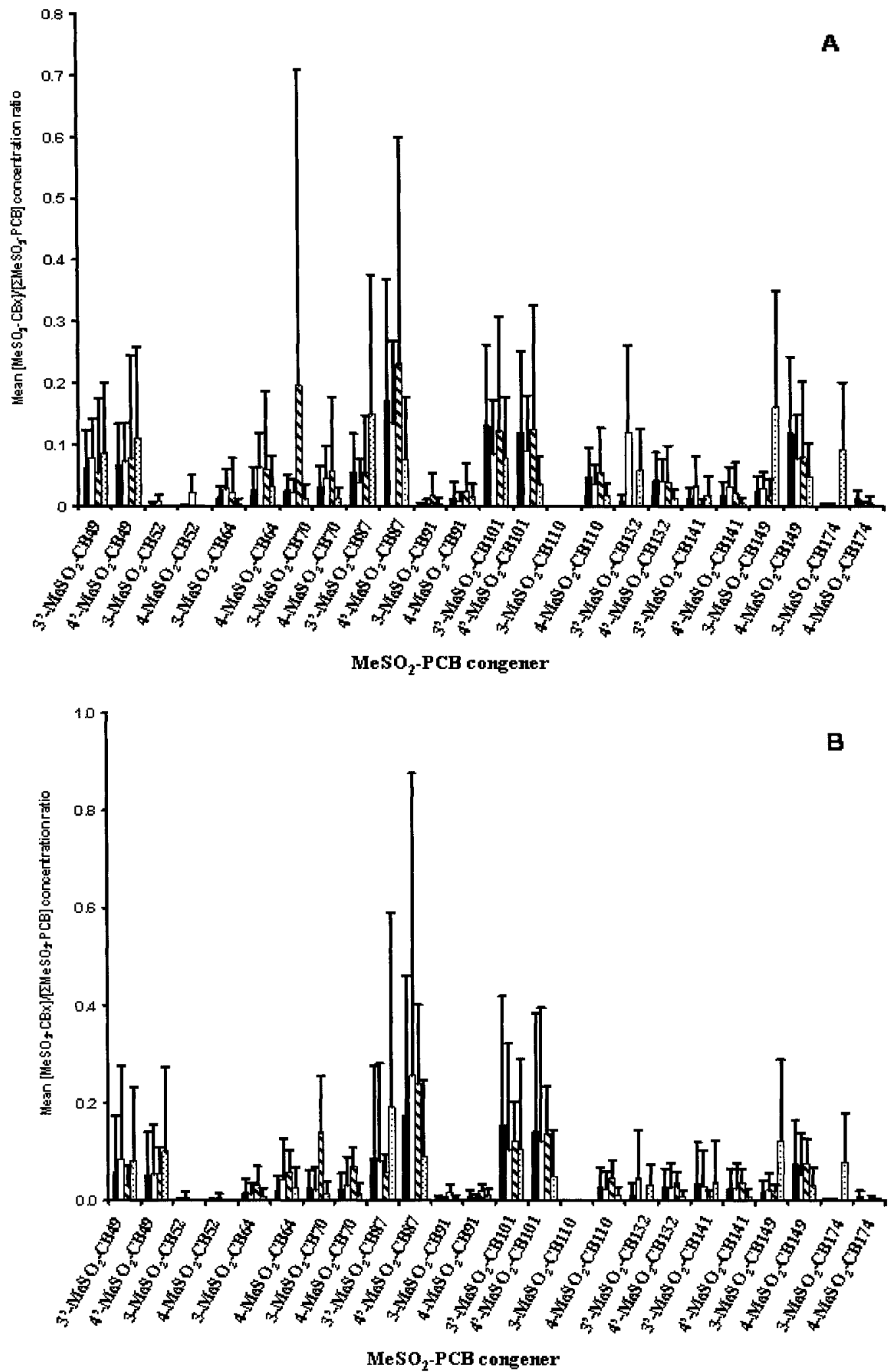

Figure 3.6. The mean ratios of the concentrations of individual $\mathrm{MeSO}_{2}-\mathrm{PCB}$ congeners to $\Sigma-\mathrm{MeSO}_{2}-\mathrm{PCB}$ in fat (black bars), blood (white bars), brain (stripped bars) and liver (dotted bars) in female (A) and male (B) polar bears from East Greenland. The error bars indicate the \pm SD of the mean ratios. 


\subsubsection{Other chlorinated phenolics}

Other HPCs (chlorinated) such as 4-OH-HpCS and PCP have been mainly detected in the blood of polar bears from Canada and East Greenland (Sandau et al., 2000; Sandala et al., 2004); however information about the tissue composition of 4-OH-HpCS and PCP in polar bears is lacking. Significantly higher $(p<0.0001)$ concentrations of $4-\mathrm{OH}-\mathrm{HpCS}$ were found in the blood and liver relative to the fat and brain (Table 3.2.). Blood concentrations in this study were comparable to blood concentrations found in earlier studies on the East Greenland as well as Canadian Arctic polar bear populations (Sandau et al., 2000; Sandala et al., 2004). The highest concentrations of 4-OH-HpCS were found in the blood which could be related to structural similarities to the thyroid hormone $\mathrm{T} 4$ and the subsequent high affinity to bind to the transport protein TTR with a RBA of 1.1 relative to T4 (Sandau et al., 2000). The biotransformation of the anthropogenic contaminant octachlorostyrene (OCS) into 4-OH-HpCS has been postulated to occur in the liver, resulting in high concentrations in the polar bear blood (Sandau et al., 2000). The low concentrations found in the fat indicate that, besides protein association, lipid association plays a minor role in the accumulation of $4-\mathrm{OH}-\mathrm{HpCS}$ in tissues. Levels in the brain could be related to accumulation in the lipids in the brain; however residual blood in the brain samples may have also contributed to the levels found.

PCP has been used as a fungicide/insecticide but can be formed metabolically from hexachlorobenzene (HCB) (Renner, 1988). In contrast to 4-OH-HpCS, the highest significant $(p<0.0003)$ concentrations of PCP were found in the liver relative to fat, blood and brain (Table 3.2). PCP blood concentrations in this study were comparable to blood 
concentrations found in earlier studies on the East Greenland populations as well as polar bears from the Canadian Arctic (Sandau et al., 2000; Sandala et al., 2004).

The 4-OH-HpCS and PCP have a high preference for accumulating in the bear liver, the organ where metabolic production from precursor compounds is most likely to occur. Besides 4-OH-HpCS being formed in the liver, other mechanisms may retain this metabolite in the liver. PCP and 4-OH-HpCS competitively bind to the transport protein TTR which is mainly produced in the liver (Sandau et al., 2000). The 4-OH-HpCS in the blood was found in comparable levels to the liver as a result of competitive binding to TTR.

\subsubsection{Brominated compounds and degradation products}

Recently, PBDE flame retardants, as well as other flame retardants such as HBCD and/or other brominated metabolic or degradation products, have been mainly reported in the fat of polar bears from Canada, Alaska, Svalbard and/or East Greenland (Wolkers et al., 2004; Verreault et al., 2005b; Dietz et al., 2006; Muir et al., 2006; Sørmo et al., 2006). With respect to PBDEs, Muir et al. (2006) demonstrated that the fat of East Greenland bears contain the highest concentrations of $\Sigma$-PBDE in populations in the western hemisphere. However, virtually nothing is known about the tissue distribution or composition of any other brominated contaminants in polar bears. 


\section{PBDES}

$\Sigma$-PBDE levels in the fat were comparable to levels reported in a recent study on samples collected in 2000-2001 from East Greenland bears (Muir et al., 2006). In the present bears, exceedingly high, significant $(p<0.0001) \Sigma$-PBDE concentrations were found in the liver relative to the fat, blood, and brain (Tables 3.2). The only known report on PBDE levels in polar bear livers showed lower levels of PBDEs compared to the present study, where only BDE-47 was detected (Kannan et al., 2005). This may be related to the fact that the PBDEs were monitored for molecular ion clusters instead of the more abundant and thus more response sensitive isotopic bromide anions. $\Sigma$-PBDE levels in the blood of the present East Greenland bears were lower than blood levels reported in Svalbard polar bears sampled in 2002-2004 (Verreault et al., 2005b). To our knowledge, the present study is the first report of PBDEs in the polar bear brain (Wolkers et al., 2004; Verreault et al., 2005b; Muir et al., 2006). In the liver $\Sigma$-PBDE levels were exceedingly high compared to the other tissues, indicating that biochemical factors other than lipid association are highly influential in the tissue-specific localization of PBDEs. For example, PBDEs have been found to bind to a FABP in the liver of Sprague-Dawley rats (Hakk et al., 2002). The FABP as well as the retinol binding protein (RBP) belong to the lipocalin protein family and hydrophobic ligands, such as retinol, can bind to the active sites of these proteins (Flower, 1996). Furthermore, polar bears possess a high concentration of Ito cells in their liver; these cells are specialized in sequestering high retinol (vitamin A) levels present in their diet, the ringed seals (Käkelä et al., 1997). Although unproven empirically, the binding of PBDEs to proteins of the lipocalin protein family, such as FABP and RBP, is likely a plausible explanation for preference 
localization of lipophilic contaminants in the liver. The big SE of the PBDe levels in the liver are due to the exceedingly high PBDE levels in five individuals, the levels were up to two oders of magnitude higher relative to te other bears. Similar retention/sequestering mechanisms in the liver of polar bears are also likely for more polar POPs such as $\mathrm{MeSO}_{2}$-PCBs and -DDEs. Non-covalent binding of PBDE congeners to liver-specific proteins may also contribute to the exceptionally high preference of PBDEs for the liver of polar bears (Tables 3.2). PCBs have been shown to bind to an unidentified liver cytosol protein in rats, leading to liver-specific sequestering in terms of tissue deposition. (Buff et al., 1992; Brundl et al., 1993). In recent studies, a preference for liver localization of PBDEs relative to blubber was reported for hooded seals from the Gulf of St. Lawrence and from humans from Sweden, where the liver to blubber/adipose concentrations were above unity and ranged from 1.7 to 2.2 (Guvenius et al., 2001; Wolkers et al., 2006). An increased capacity to store vitamin A in the liver is also known for pinnepids (Käkelä et al., 1997).

No significant difference was observed in the PBDE congener pattern for the tissues of the present East Greenland bears (Figure 3.7). BDE-47 and BDE-153 were the major BDE congeners in the pattern which was consistent with very recent studies on PBDEs in fat from several polar bear populations (Wolkers et al., 2004; Verreault et al., 2005; Muir et al., 2006; Sørmo et al., 2006). Although BDE-154 chromatographically co-elutes with any BB-153 that may be present; it was found to be a major congener in the PBDE pattern for all the polar bear tissues. The tissue composition trends showed that BDE-154 was comparable to BDE-47 in the proportion of $\Sigma$-PBDEs in fat (Figure 3.7), although 


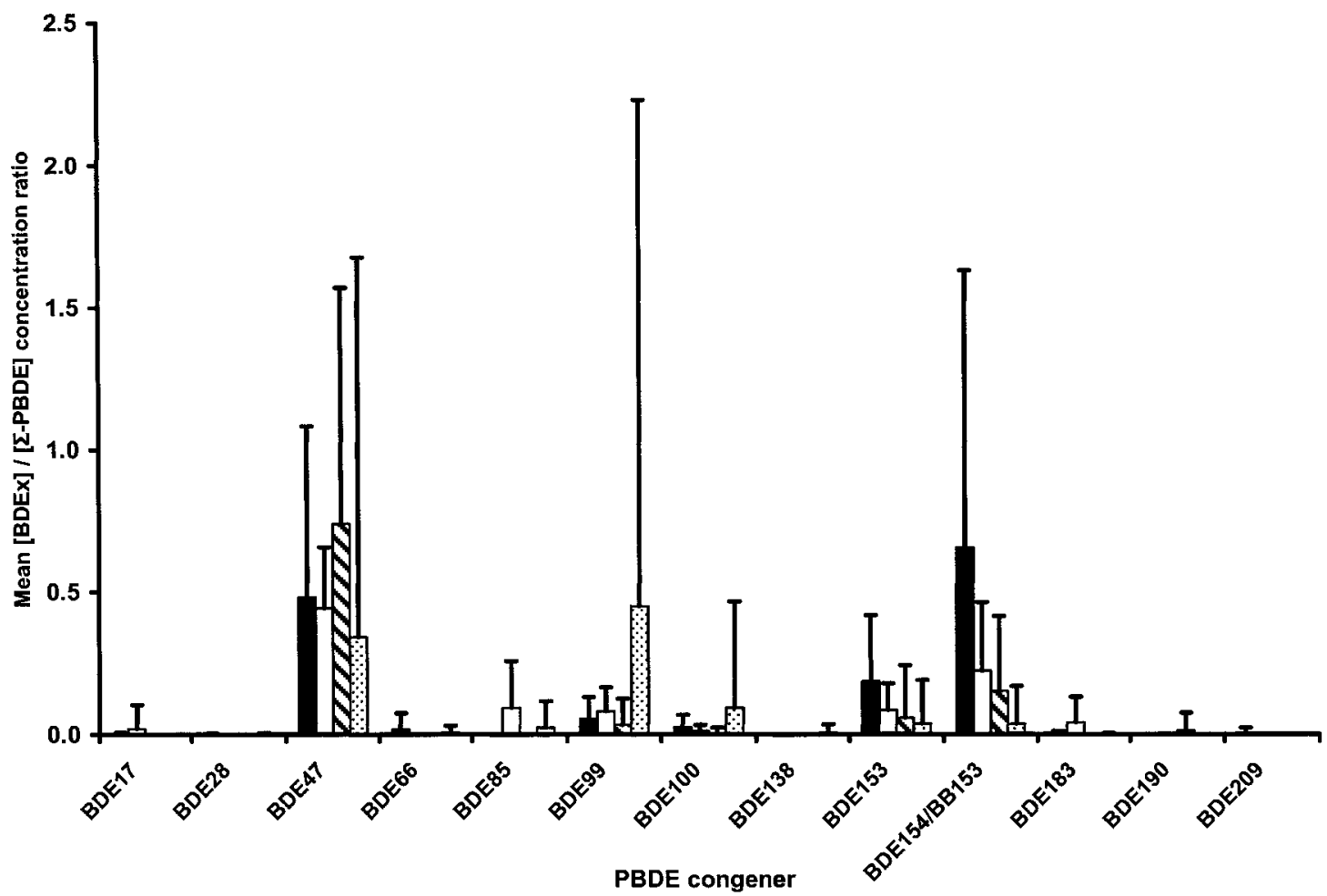

Figure 3.7. The mean ratios of the concentrations of individual PBDE congeners to $\Sigma$-PBDE in fat (black bars), blood (white bars), brain (stripped bars) and liver (dotted bars) in male and female $(n=20)$ polar bears from East Greenland. The error bars indicate the \pm SD of the mean ratios. 
this appeared to not be true for the brain, liver and blood. In recent studies, BDE-154 was found to be a minor congener in polar bear fat, and more dominant than BDE-153 in polar bear blood, which is consistent with the present data (Verreault et al., 2005b; Muir et al., 2006).

\section{Total-( $(\alpha)-H B C D$}

The measured $\alpha-\mathrm{HBCD}$ is termed total-( $\alpha)$-HBCD since $\alpha-\mathrm{HBCD}$ has been observed to preferentially accumulate in biota (Covaci et al., 2006). Both $\beta$ - and $\gamma$-HBCD are thermally isomerized to $\alpha-\mathrm{HBCD}$ at the presently used GC ramping temperatures above $160^{\circ} \mathrm{C}$. Total-( $\left.\alpha\right)$-HBCD was presently only detected in polar bear fat. In the other tissues, especially in the liver where the highest levels of other POPs were found, total( $\alpha$-HBCD was not detected. The levels found in the fat were comparable to earlier reports on fat levels in East Greenland and Svalbard polar bears (Muir et al., 2006; Sørmo et al., 2006). Although total-( $\alpha)$-HBCD has not been detected in the polar bear blood in the present study, total-( $\alpha)-\mathrm{HBCD}$ was detected in the plasma of Svalbard polar bears (Verreault et al., 2005b). The biotransformation of total-( $\alpha)-\mathrm{HBCD}$ may have resulted in non-detectable levels in the liver; polar bear hepatic microsomes were observed to be able to oxidatively deplete $\alpha-\mathrm{HBCD}$ (see Chapter 4 ). Oxidative metabolism of HBCDs was recently shown to occur in marine mammals in a study by Zegers et al. (2005). OHHBCD metabolites were detected after exposing harbour seal (hepatic) microsomes to $\beta$ and $\gamma$-HBCD. In white-sided dolphins from the coast of Massachusetts, total-( $\alpha)$-HBCD was detected in the liver, at low concentrations in comparison to their blubber; i.e., 18 $\mathrm{ng} / \mathrm{g}$ wet wt and $81 \mathrm{ng} / \mathrm{g}$ wet wt, respectively (Peck et al., 2005). 


\section{PBBs}

Although BB-101 was only quantifiable in three of the bears' liver samples, it was the only PBB congener identified in the present polar bear samples, and thus is synonymous with the $\Sigma$-PBBs since any BB-153 would be chromatographically and mass spectrally unresolved from BDE-154. The three liver samples also contained the highest $\Sigma$-PBDE concentrations of all polar bear livers. For PBBs, a similar mechanism of PBDE retention in the liver appears to exist, which may be a function of protein binding and preferential Ito cell sequestering as described for PBDEs and other more polar organohalogens such as the $\mathrm{MeSO}_{2}-\mathrm{PCBs}$ and 3-MeSO $2-p, p^{\prime}-\mathrm{DDE}$. To our knowledge PBBs have not been reported in any of the polar bear tissues.

\section{OH-PBDES}

$\Sigma$-OH-PBDE was found in the polar bear fat and blood. The highest concentration was detected in the blood, but was not significantly $(p>0.05)$ different from the fat (Table 3.2). The only study that determined OH-PBDEs in any polar bear tissue, showed plasma concentrations in bears from Svalbard, which were one order of magnitude lower in comparison to the present East Greenland bears (Verreault et al., 2005b). Concentrations of PBDEs (possible metabolic precursors of OH-PBDEs) in the blood of polar bears from Svalbard (533 ng/g lipid wt) were found to be higher compared to the present East Greenland polar bears (93 ng/g lipid wt). The possible capacity of PBDE to biotranform to OH-PBDEs in East Greenland polar bears would appear to be higher compared to the capacity in Svalbard bears. Only two OH-BDE congeners were detected; 6-OH-BDE47 only in the fat, and 3-OH-BDE47 mainly in the blood but also in the fat. The 3-OH- 
BDE47 congener has structural similarities to the thyroid hormone $\mathrm{T} 4$, and has been observed to bind with higher affinity $(\mathrm{RBA}=3.8)$ to the transport protein TTR (human) relative to the natural ligand, T4 (Malmberg, 2004). The 6-OH-BDE47 had a lower binding affinity to TTR $(\mathrm{RBA}=0.3)$ than $\mathrm{T} 4$ due to lesser structural similarities. One hypothesis may be that an $\mathrm{OH}$-group on the ortho position of the brominated diphenyl ether backbone may have resulted in a greater lipid association since 6-OH-BDE47 appears to be only associated with fat in the present polar bears.

Several OH-BDE congeners have been detected in the polar bear plasma (Verreault et al., 2005b); however, the two congeners found in this study have previously not been detected in any polar bear tissues. For the present bears, the $\Sigma$-OH-PBDE to $\Sigma$-PBDE concentration ratio (regardless of wet or lipid wt basis) corroborated the fact that $\mathrm{OH}-$ PBDEs have a preference for retention in the blood relative to fat tissues (Table 3.3). The apparent lower metabolite/precursor ratio for $\Sigma$-OH-PBDE to $\Sigma$-PBDE relative to $\Sigma$-OHPCB to $\Sigma$-PCB suggests that oxidative metabolism of PBDEs (see Chapter 4) is not as important relative to oxidative metabolism of PCBs.

\section{MeO-PBDES}

$\Sigma$-MeO-PBDE levels were found to be the highest in the liver followed by the fat and blood, in the polar bear brains MeO-PBDEs were not detected (Table 3.2.). In less than $50 \%$ of the fat and blood the MeO-PBDEs were above the MLOQ, therefore it was statistically not possible to reliably determine the significance of $\Sigma$-MeO-PBDE concentration differences between the tissues. The only report known on MeO-PBDEs in 
polar bears showed blood concentrations in Svalbard bears that were comparable to the blood levels of the present East Greenland bears (Verreault et al., 2005b). Six MeOPBDE congeners were detected in the polar bear tissues, but only two of them, 6'-MeOBDE17 and 6-MeO-BDE47, were detected in more than one tissue. In the livers, four of the six detected congeners were present (Figure 3.8). The 3-MeO-BDE47, 6-MeOBDE47 and 4'-MeO-BDE49 that were detected in the polar bear fat, blood and/or liver have previously been detected in the plasma from Svalbard polar bears (Verreault et al., 2005b). In the present bears, ortho-MeO-substituted PBDEs appeared to favour retention in the fat and blood, while meta- and para-MeO-substituted PBDEs favour the liver. The reasons for the apparent tissue-specificity for MeO-PBDEs are unclear. However, the non-detectable levels of OH-PBDEs in the brain and liver, and MeO-PBDEs in the brain might be due to overall low levels of these contaminants in the polar bear body. With respect to the brain, the $\mathrm{BBB}$ appears to be an effective barrier restricting the passage of $\mathrm{OH}-\mathrm{PBDEs}$ and MeO-PBDE regardless of their metabolic and/or accumulative origin. The 6-OH/MeO-BDE47 and 2'-OH/-MeO-BDE68 analogue pairs, as well as other ortho $\mathrm{OH}-\mathrm{MeO}$-substituted PBDEs have been shown to be of natural origin in Dysidea herbacea, Dysidea chlorea and Phyllospongia foliascens marine sponges and in the Odonthalia corymbifera red algae (Carté et al., 1981; Kurihara et al., 1999). These natural compounds have been detected in species higher up in the food chain such as whales and dolphins (Vetter et al., 2002; Teuten et al., 2005). This indicates that these compounds possess lipophilic properties and have appreciable environmental half-lives. 


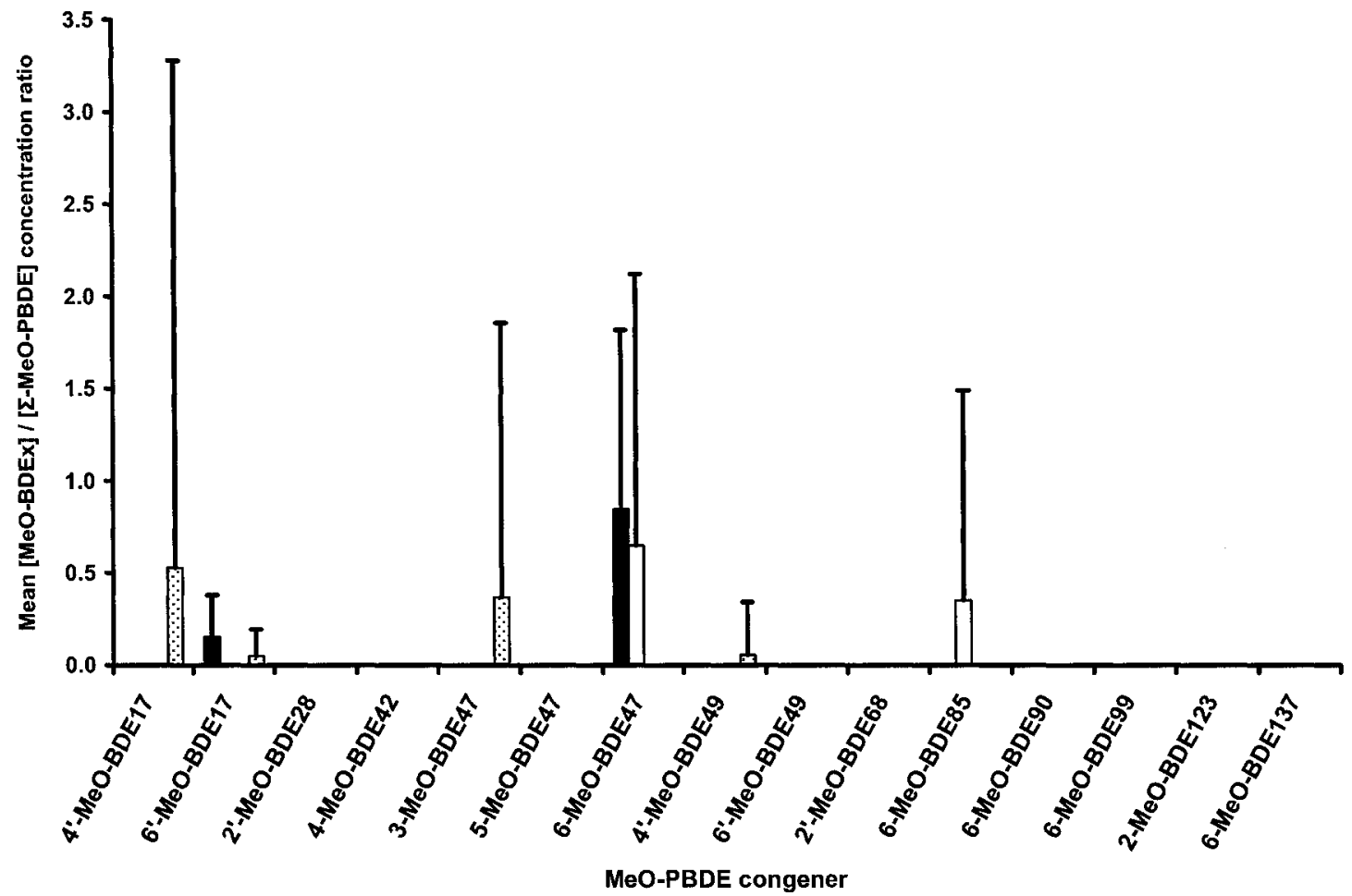

Figure 3.8. The mean ratios of the concentrations of individual MeO-PBDE congeners to $\Sigma$-MeO-PBDE in fat (black bars), blood (white bars), brain (stripped bars) and liver (dotted bars) in male and female ( $\mathrm{n}=20)$ polar bears from East Greenland. The error bars indicate the $\pm \mathrm{SD}$ of the mean ratios. 


\section{OH-PBBS}

Several previously unknown HPCs (brominated) were detected in the polar bear tissues with variable ion abundances in the corresponding ECNI mass spectra (Figure 3.9, for mass spectra of unknowns see Appendix 3). GC-MS(ECNI) full scan mass spectra showed the isotopic ion clusters for $\mathrm{Br}^{-}\left(m / z\right.$ 79) and $\mathrm{Br}_{2}^{-}(m / z 161)$ for all the unknowns. Unknown 1 showed additional negative ion clusters at $m / z 247,325$ and 405, and all the 3 isotopic ion clusters were separated by the mass of $\mathrm{Br}^{-}$. Since no isotopic ion clusters higher than $m / z 405$ were detected, it was assumed that $m / z 405$ was the molecular ion cluster. All the three unknowns were eluting at the same retention time as tri- and tetrabrominated $\mathrm{OH}-\mathrm{PBDEs}$, and it was therefore assumed that the $\mathrm{OH}$-containing unknowns were either tri- or tetra-brominated based on comparable temperature-dependent volatilities that influence GC elution times. A possible structure for unknown 1 could be tri-brominated $\mathrm{OH}-\mathrm{PBB}$ with $m / z 405$ being the $[\mathrm{M}-15]^{-}$ion. The [M-15] ion is a common ion for OH-PCBs (Sandau, 2000b). Unknown 2, with ion clusters at $m / z 403$ and 483, was thought to be a tetra-brominated OH-PBB, and unknown 3 with ion cluster at $m / z 325,405$ and 481 was also thought to be a tetra-brominated OH-PBB.

Confirmation of the molecular mass of the unknown and apparent OH-PBBs was determined by GC-HRMS(EI). In full scan mode, the isotopic ion clusters $\left[\mathrm{M}-\mathrm{CH}_{3}\right]^{+}$and $\left[\mathrm{M}-2 \mathrm{Br}-\mathrm{CH}_{3}\right]^{+}$were found for unknown 2. Ions of hydrocarbon contamination in the solvent (TMP) co-eluted with unknown 1, and made it impossible to identify unknown 1 by GC-HRMS(EI). Unknown 3 was detected in the full scan, but the sensitivity of this compound was very poor, and thus no determination of the exact molecular mass could 
Table 3.4. The mean ( $\pm \mathrm{SE}$ ) of concentrations $(\mathrm{ng} / \mathrm{g}$ ww) of apparent $\mathrm{OH}-\mathrm{PBB}$ congeners in female and male polar bear tissues from East Greenland.

\begin{tabular}{|c|c|c|c|c|c|c|c|c|c|}
\hline Unknown & $\overline{\operatorname{Sex}}$ & Fat & $\begin{array}{c}\text { No. Samples } \\
>\text { MLOQ }\end{array}$ & Blood & $\begin{array}{c}\text { No. Samples } \\
>\text { MLOQ }\end{array}$ & Brain & $\begin{array}{c}\text { No. Samples } \\
>\mathrm{MLOQ}\end{array}$ & Liver & $\begin{array}{c}\text { No. Samples } \\
>\text { MLOQ }\end{array}$ \\
\hline$\# 1$ & Female & $4.8 \pm 3.1$ & 5 & $0.23 \pm 0.22$ & 5 & $3.2 \pm 1.0$ & 8 & $1.1 \pm 0.6$ & 5 \\
\hline$\# 2$ & $(n=10)$ & n.d. & 0 & n.d. & 0 & n.d. & 0 & n.d. & 0 \\
\hline$\# 3$ & & n.d. & 0 & $0.26 \pm 0.01$ & 4 & $3.1 \pm 1.0$ & 8 & $3.6 \pm 2.4$ & 6 \\
\hline$\# 1$ & Male & $9.9 \pm 6.5$ & 9 & $0.03 \pm 0.02$ & 4 & $7.5 \pm 5.1$ & 6 & $0.6 \pm 0.4$ & 4 \\
\hline$\# 2$ & $(n=10)$ & $3.1 \pm 3.1$ & 1 & n.d. & 0 & n.d. & 0 & n.d. & 0 \\
\hline$\# 3$ & & $11 \pm 10$ & 2 & $0.006 \pm 0.004$ & 3 & $5.6 \pm 3.6$ & 5 & $1.2 \pm 0.5$ & 5 \\
\hline
\end{tabular}




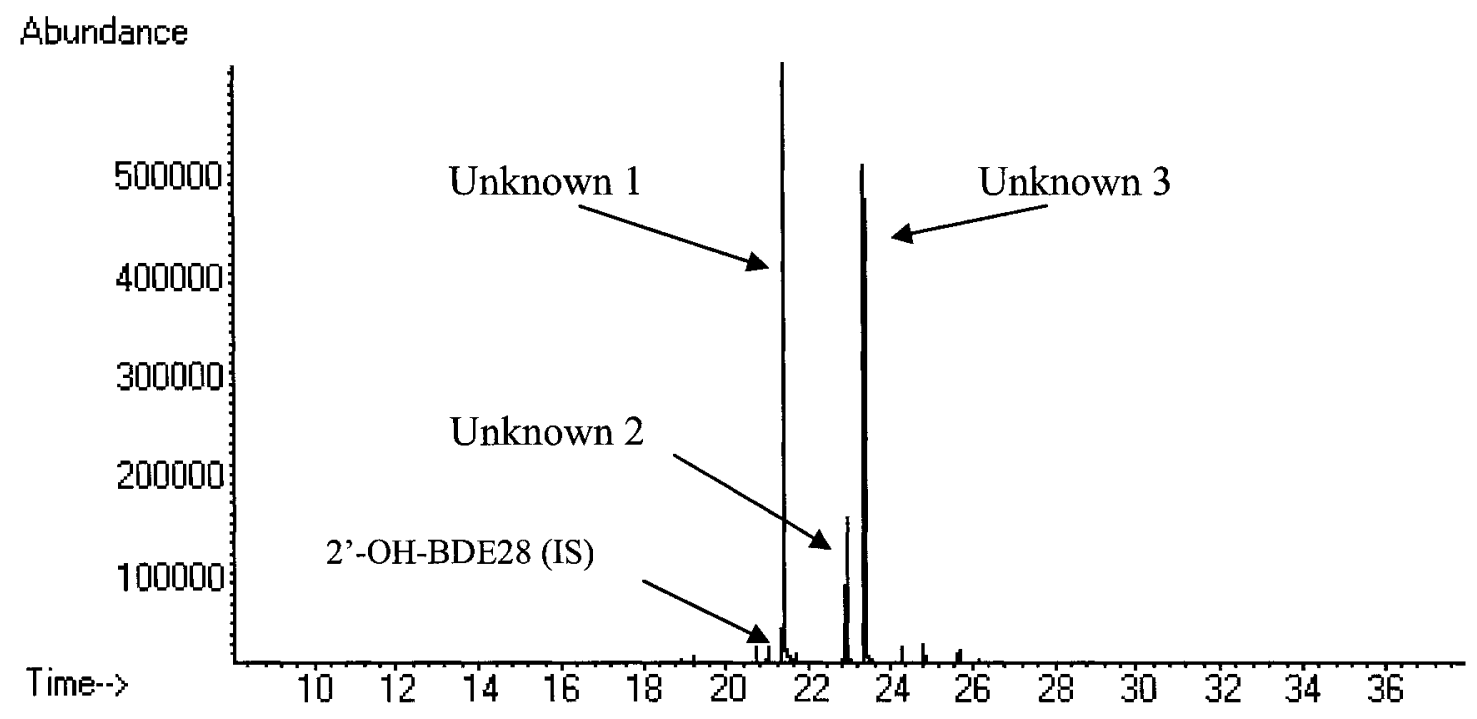

Figure 3.9. GC-MSD (ECNI) $(\mathrm{m} / z$ 79/81) chromatogram of the brominated phenolic compound fraction from polar bear fat (derivatized to their corresponding $\mathrm{MeO}-$ compounds) 
be made. The masses of the $\left[\mathrm{M}-\mathrm{CH}_{3}+2\right]^{+},\left[\mathrm{M}-\mathrm{CH}_{3}+4\right]^{+},\left[\mathrm{M}-\mathrm{CH}_{3}+6\right]^{+}$ions in the $[\mathrm{M}-$ $\left.\mathrm{CH}_{3}\right]^{+}$isotopic ion cluster of unknown 2 were all within $0.04 \mathrm{amu}$ of the theoretical masses. Furthermore, the masses of $\left[\mathrm{M}-2 \mathrm{Br}-\mathrm{CH}_{3}\right]^{+},\left[\mathrm{M}-2 \mathrm{Br}-\mathrm{CH}_{3}+2\right]^{+},\left[\mathrm{M}-2 \mathrm{Br}-\mathrm{CH}_{3}+4\right]^{+}$ ions in the $\left[\mathrm{M}-2 \mathrm{Br}-\mathrm{CH}_{3}\right]^{+}$isotopic ion cluster of unknown 2 were all within $0.03 \mathrm{amu}$ of the theoretical masses. Although GC-HRMS(EI) confirmation was only possible for unknown 2, it is highly probable that unknowns 1 and 3 are OH-PBBs as well due to the similar mass spectra obtained by GC-MS(ECNI).

The present finding suggests that the $\mathrm{OH}-\mathrm{PBBs}$ found in the polar bears may also be, in part, of natural origin and were subsequently accumulated in the polar bear food chain. Isnansetyo et al. (2003) identified 2,2'-diOH-BB80 to be a natural compound produced by a marine sponge, Pseudoalteromonas phenolica (Tokyo, Japan). The methoxylated analogue, 2,2'-diMeO-BB80, was recently detected in marine mammals, and was thought to be the methylated form of the natural product 2,2'-diOH-BB80 (Marsh et al., 2005). Bacteria have been shown to be able to methylate brominated phenolic compounds (Allard et al., 1987).

\subsubsection{Comparisons and contrasts with "legacy" organochlorines POPs}

Several organochlorine pesticides, such as chlorobenzenes, hexachlorohexanes, CHLs and DDT related compounds, have been monitored mainly in the polar bear fat in populations from across the western hemisphere (Norstrom et al., 1998; Verreault et al., 2005a). However, the tissue distribution or composition of these OC pesticides is not 
well described in the literature (Braune et al., 2005). In the present study, CHLs and DDTs are used as comparative legacy classes to put into perspective the importance of the aforementioned "emerging" classes of chlorinated and brominated contaminants with respect to exposure in the present East Greenland polar bears.

$\Sigma$-CHL concentrations were found to be significantly $(p<0.0001)$ highest in the polar bear liver, followed by concentrations in the fat and blood, and the significantly $(p<0.0001)$ lowest levels being in the brain (Table 3.2.). $\Sigma$-DDT levels were found to be the highest in the liver and blood compared to the fat and brain (Table 3.2), there was no significant $(p>0.05)$ difference between the $\Sigma$-DDT levels in the tissues. For both $\Sigma$-CHLs and $\Sigma$ DDTs, comparable levels were reported in the fat, blood and liver samples from polar bears from Canadian and East Greenland populations (Wiberg et al., 2000; Dietz et al., 2004; Sandala et al., 2004).

Comparing the tissue distribution of the legacy POPs, such as CHLs, DDTs and PCBs, to the more emerging POPs, like PBDEs and $\mathrm{MeSO}_{2}-\mathrm{PCBs}$, there is a similar trend among tissues. In the liver the highest concentrations of the legacy as well as the emerging POPs were found. The levels in the fat and blood were comparable to each other and overall significantly $(p<0.03)$ lower than in the liver. The brain concentrations of both legacy and emerging POPs were overall significantly $(p<0.0002)$ lower compared the concentrations in all the other tissues. The similar distribution amongst tissues of the different compound classes indicates similarities amongst the classes, i.e., chemical structure or physico-chemical properties $\left(K_{\mathrm{OW}}\right)$. These similarities resulted in similar 
accumulation mechanism in the tissues, i.e., accumulation in the lipids, or even possible protein binding.

\subsubsection{Total tissue and body burden of organohalogens}

To estimate the total body exposure of polar bears to the POPs, total amounts were calculated per tissue and in the blood. Girth and length measurements of the polar bears were available, which made it possible to calculate the weight of the bears using a linear regression model (Derocher et al., 2002). Linear regression models were also used to calculate the mass of the blood, brain and liver related to the body weight of the bear (Prothero, 1980, 1982; Armstrong, 1983). Although these models for the blood, brain and liver were not specifically for polar bears, the large variety of mammals used in those models showed a comparable linearity for all mammals. The percent body fat of the bears was based on Atkinson et al. (1996) (personal communication also from Dr. A. Derocher, University of Alberta). The fat content in a polar bear is highly variable thoughout the year, where the bears go through an extensive fasting period where the percent body fat can drop from $50 \%$ to less than $10 \%$. In this study, the bears sampled in June, July and August were estimated to have $50 \%$ body fat, at this time of the year the bears are at their fattest and go on land for several months of fasting. Bears sampled in September, a month or two after the start of the fasting, were estimated to have $30 \%$ body fat. Polar bears sampled in the winter (January and February) and spring (March - May) were estimated to have $20 \%$ and $30 \%$ body fat, respectively. During the winter the bears return to the ice and begin to replenish their fat stores via vigorous feeding on seals. 
The total amounts of organohalogens in each tissue and blood were calculated by multiplying the concentration in the body compartment in $n g / g$ wet wt $(=\mathrm{ug} / \mathrm{kg}$ ) times the estimated weight of the compartment in $\mathrm{kg}$. For calculating the total amounts of contaminants in the blood the assumption was made that one liter of blood equals one $\mathrm{kg}$. Based on the total amounts in the polar bear body compartments, the highest levels of the POPs were found in the fat, making up $>86 \%$ of the total amount of the POP found in the four body compartments even thought the highest concentrations were found in the liver (Table $3.1,3.2 \& 3.5)$. The average weight of the body fat in a polar bear $(\sim 147 \mathrm{~kg})$ is many times higher than the average weight of the liver $(\sim 8 \mathrm{~kg})$. As seen with the concentrations of HPCs, the total amount of HPCs was found in the blood despite the fact that the weight of body fat is 4 times higher than the weight of the blood (Table 3.5.). Over $78 \%$ of the OH-PCB body burden is estimated to be present in the blood, with around $20 \%$ being accounted for in the fat. In contrast, and albeit at much lower concentrations, the OH-PBDEs were found at comparable quantities in the blood and fat. At the opposite extreme, the OH-PBB body burden was essentially all in the fat $(\sim 99 \%)$. Even though they have comparable backbone structures, these HPC classes (i.e., OHPCBs, OH-PBDEs, and OH-PBBs) appear to be influenced by different toxicokinetic factors that determine the tissue-specific formation, localization and concentrations. Bromination rather chlorination appears to render the biphenyl base structure to be more lipophilic and thus brominated phenolic compounds accumulated in major lipid depots such as the fat. Contrary to what the high concentrations of POPs in the liver might have indicated, the absolute amounts are lower compared to the fat with the exception of 
Table 3.5. Total amounts $(\mu \mathrm{g} \pm \mathrm{SE})$ of classes of neutral and phenolic organohalogen compounds in the several tissues and blood of female and male polar bear tissues from East Greenland.

\begin{tabular}{|c|c|c|c|c|c|c|c|c|c|}
\hline Analyte & Fat & $\begin{array}{l}\% \text { of } \\
\text { total }\end{array}$ & Blood & $\begin{array}{l}\% \text { of } \\
\text { total }\end{array}$ & Brain & $\begin{array}{l}\% \text { of } \\
\text { total }\end{array}$ & Liver & $\begin{array}{l}\% \text { of } \\
\text { total }\end{array}$ & $\begin{array}{c}\text { Total } \\
\text { analyte }(\mu \mathrm{g}) \\
\end{array}$ \\
\hline$\Sigma-\mathrm{PCB}$ & $840,380 \pm 116,287$ & $96 \pm 58$ & $1,530 \pm 261$ & $0.18 \pm 0.13$ & $18 \pm 3$ & $0.002 \pm 0.001$ & $25,039 \pm 4045$ & $2.8 \pm 2.0$ & $866,967 \pm 116,357$ \\
\hline$\Sigma$-OH-PCB & $8,563 \pm 999$ & $16 \pm 2$ & $40,617 \pm 8163$ & $78 \pm 16$ & $2.5 \pm 0.7$ & $0.005 \pm 0.001$ & $2,851 \pm 373$ & $5.5 \pm 0.7$ & $52,034 \pm 8,232$ \\
\hline$\Sigma-\mathrm{CHL}$ & $134,446 \pm 22,883$ & $85 \pm 11$ & $236 \pm 35$ & $0.12 \pm 0.02$ & $1.5 \pm 0.5$ & $0.001 \pm 0.001$ & $29,883 \pm 3,307$ & $15 \pm 2$ & $203,566 \pm 23,120$ \\
\hline$\Sigma$-DDT & $58,318 \pm 9,224$ & $96 \pm 15$ & $981 \pm 394$ & $1.6 \pm 0.6$ & $0.74 \pm 0.71$ & $0.001 \pm 0.001$ & $1,754 \pm 421$ & $2.9 \pm 0.7$ & $61,055 \pm 9,242$ \\
\hline $\mathrm{MeSO}_{2}$-DDE & $2,524 \pm 1,315$ & $86 \pm 45$ & $4.3 \pm 0.8$ & $0.15 \pm 0.03$ & - & - & $723 \pm 78$ & $14 \pm 3$ & $2,951 \pm 1317$ \\
\hline 4-OH-HpCS & $99 \pm 10$ & $19 \pm 2$ & $356 \pm 60$ & $70 \pm 12$ & $0.11 \pm 0.02$ & $0.021 \pm 0.004$ & $56 \pm 10$ & $11 \pm 2$ & $511 \pm 62$ \\
\hline PCP & $205 \pm 91$ & $87 \pm 39$ & $4.1 \pm 1.7$ & $1.8 \pm 0.7$ & $0.03 \pm 0.01$ & $0.011 \pm 0.002$ & $26 \pm 4$ & $11 \pm 2$ & $236 \pm 91$ \\
\hline$\Sigma-\mathrm{PBDE}$ & $11,574 \pm 2,190$ & $16 \pm 3$ & $41 \pm 5$ & $0.05 \pm 0.01$ & $0.3 \pm 0.1$ & $0.001 \pm 0.001$ & $63,049 \pm 45,743$ & $84 \pm 61$ & $74,665 \pm 45,796$ \\
\hline Total- $(\alpha)-\mathrm{HBCD}$ & $3,470 \pm 896$ & $100 \pm 26$ & - & - & - & - & - & - & $3,470 \pm 896$ \\
\hline$\Sigma$-PBB & - & - & - & - & - & - & $21 \pm 17$ & $100 \pm 81$ & $21 \pm 17$ \\
\hline$\Sigma$-OH-PBDE & $110 \pm 41$ & $47 \pm 18$ & $123 \pm 192$ & $53 \pm 19$ & - & - & - & - & $233 \pm 60$ \\
\hline$\Sigma$-MeO-PBDE & $800 \pm 332$ & $63 \pm 26$ & $7.2 \pm 2.8$ & $0.6 \pm 0.2$ & - & - & $470 \pm 276$ & $37 \pm 22$ & $1,278 \pm 432$ \\
\hline$\Sigma$-OH-PBB & $3,614 \pm 3,033$ & $99 \pm 83$ & $6.3 \pm 5.2$ & $0.2 \pm 0.1$ & $1.3 \pm 0.7$ & $0.04 \pm 0.02$ & $29 \pm 11$ & $1.8 \pm 0.3$ & $3,650 \pm 3,033$ \\
\hline $\begin{array}{l}\text { Sum in } \\
\text { tissue }(\mu \mathrm{g})\end{array}$ & $1,200,183 \pm 141,151$ & & $44,140 \pm 9,526$ & & $26 \pm 4$ & & $146,411 \pm 55,257$ & & $1,390,759 \pm 151,881$ \\
\hline
\end{tabular}


PBDEs and PBBs. We observed tissue-specific preference for retention in the liver of BB-101 and PBDEs, whereas PCBs favour fat deposition. In the brain the total amount of the POPs found were the lowest amongst the body compartments, accounting for only about $0.002 \%$ of the body burden of all the POPs.

\subsubsection{Implications of organohalogen exposure and tissue composition in polar bears}

As seen in the literature with other species, in the present polar bears most neutral lipophilic compounds, such as $\mathrm{PCBs}, \mathrm{MeSO}_{2}-\mathrm{PCBs}$, OC pesticides, PBDEs and PBBs, had the highest concentrations in the liver relative to other tissues (Letcher et al., 1998; Guvenius et al., 2001, 2002; Wolkers et al., 2006). As discussed previously, besides lipid association and depending on the chlorinated or brominated contaminant class in question, protein binding appears to be an important biochemical factor with respect to the selective retention in the polar bear liver. For example, several of these lipophilic compounds ( $\mathrm{MeSO}_{2}-\mathrm{PCBs}$ and PBDEs) have been found to bind to liver proteins from the lipocalin protein family, such as the FABP (Larsen et al., 1991, 1992; Haraguchi et al., 1997; Letcher et al., 2000; Hakk et al., 2002).

The fat depot plays an important role in the overall body burden of the present chlorinated and brominated contaminants, analogues and by-products in the polar bear. Even though the highest concentrations of POP classes per tissue was almost entirely found in blood and liver, when calculated on a total tissue burden basis, the fat contained over $86 \%$ of the sum contaminants in the tissues and body compartments. The overall burden of brominated POPs (i.e., PBDEs and PBBs) and chlorinated metabolites (i.e., 
$\mathrm{OH}-\mathrm{PCBs}$ and 4-OH-HpCS) was found to be minor in the fat relative to the liver and blood, respectively. Therefore, by assessing and/or monitoring all the organohalogens in the fat, we are underestimating the presence and exposure (tissue-specific) of polar bears to these xenobiotics, especially for an increasing number of "emerging" contaminants that appear to be more protein associated.

The highest concentrations of most HPCs (e.g., OH-PCB, 4-OH-HpCS and OH-PBDE) were found in the blood. Due to structural similarities of the phenolic contaminants with the thyroid hormone $\mathrm{T} 4$, there was high affinity of these contaminants to binding to the transport protein TTR in the blood. The RBA of several halogenated phenolic contaminants varied from 0.3 to 6.6 , a RBA greater than one indicate that there is competitive binding of the contaminants versus T4 to TTR (Sandau et al., 2000a; Malmberg, 2004). These brominated and chlorinated phenolic contaminants, as well as their precursors have been shown to bind with a high affinity to TTR, resulting in reduced T4 blood concentrations. In polar bears from Svalbard, concentrations of several of these POPs were linearly correlated with reduced T4 and retinol levels in the blood (Skaare et al., 2001).

In the brain, concentrations of both neutral and phenolic contaminants were lower compared to any other tissue. The POP burden in the brain was estimated to be less than $0.002 \%$ of the burden in the three tissues and blood. Responsible for the lower concentrations could be the different lipid composition in the brain compared to other tissues. Tilbury et al. (1997) concluded that not the percent lipid in the brain, but the 
proportion of neutral lipids in the brain of harbour porpoise could be a primary factor affecting lipophilic contaminant accumulation in the brain. The BBB might also play a role in the reduced levels in the brain; it is known that the $\mathrm{BBB}$ serves as a protective barrier, although lipophilic compounds can migrate through the barrier. There were no differences seen in the congener patterns of the POPs in brain compared to the blood, it appears that the $\mathrm{BBB}$ is not congener selective but is able to reduce total levels from entering the brain.

An important point to consider when hypothesizing the distribution of halogenated phenolics in the brain is the ability of TTR to bind to these compounds and alter their distribution. In humans, the three thyroxine transport protein (TTR, TGB and albumin) are synthesized by the liver, but only TTR is synthesized in the brain (i.e., epithelial cells of the choroid plexus) (Dickson et al., 1978). All the newly synthesized TTR is transported through the brain into the celebrospinal fluid (CSF). In fact, there exists a 30fold higher ratio of TTR to albumin concentration in the CSF than in blood plasma. TTR in CSF serves as the main T4 transport protein (Scheiber et al., 2001). Since TTR is synthesized in the coroid plexus and is secreted into CSF, it is possible that these tissues retain higher levels of $\mathrm{OH}-\mathrm{PCBs}$, OH-PBDEs and other halogenated phenolic compounds, specifically compounds that have a high affinity for TTR. Recently, Takasuga et al. (2004) observed that levels of OH-PCBs in human CSF were higher than levels of PCBs, which was reversed in the serum. Chemical analysis has been limited in marine mammal brains. Studies have not addressed whether or not contaminants bioaccumulate in specific brain regions. Furthermore, our understanding of the 
distribution and bioaccumulation of halogenated phenolics in the brain of polar bears is non-existent. Many of these POP classes have showed to have endocrine disrupting and neurotoxic properties (Letcher et al., 2000; Sharma et al., 2002; Meerts et al., 2004; Hamers et al., 2006). Thyroid hormones, like T4, have major effects on the development of the brain in utero and during the neonatal period. Neonatal hypoththyroidism in humans can cause mental retardation and neurological defects (Yen, 2001). 


\section{References}

Allard, A.-S., Remberger, M., and Neilson, A. H., 1987. Bacterial O-methylation of halogen-substituted phenols. Applied and Environmental Microbiology 53, 839845.

Armstrong, E., 1983. Relative brain size and metabolism in mammals. Science 220, $1302-1304$.

Atkinson, S.N., Nelson, R.A., Ramsay, M.A., 1996. Changes in the body composition of fasting polar bears (Ursus maritimus): the effect of relative fatness on protein conservation. Physiological Zoology 69, 304-316.

Braune, B.M., Outridge, P.M., Fisk, A.T., Muir, D.C.G., Helm, P.A., Hobbs, K., Hoekstra, P.F., Kuzyk, Z.A., Kwan, M., Letcher, R.J., Lockhart, W.L., Norstrom, R.J., Stern, G.A., and Stirling, I., 2005. Persistent organic pollutants and mercury in marine biota of the Canadian Arctic: an overview of spatial and temporal trends. The Science of the Total Environment 351-352, 4-56.

Bründl, A. and Buff, K., 1993. Partial purification and characterization of a rat liver polychlorinated biphenyl (PCB) binding protein. Biochemical Pharmacology 45, 885-891.

Buff, K. and Bründl, A., 1992. Specific binding of polychlorinated biphenyls to rat liver cytosol protein. Biochemical Pharmacology 43, 965-970.

Carté, B. and Faulkner, D.J. 1981. Polybrominated diphenyl ethers from Dysidea herbacea, Dysidea chlorea and Phyllospongia foliascens. Tetrahedron 37, 23352339.

Covaci, A., Gerecke, A.C., Law, R.J., Voorspoels, S., Kohler, M., Heeb, N.V., Leslie, H., Allchin, C.R., De Boer, J., 2006. Hexabromocyclododecanes (HBCDs) in the environment and humans: a review. Environmental Science and Technology 40, 3679-3688.

Derocher, A. E. and Wiig, Ø., 2002. Postnatal growth in body length and mass of polar bears (Ursus maritimus) at Svalbard. Journal of Zoology 256, 343-349.

Dickson, P.W., Aldred, A.R., Menting, J.G.T., Marley, P.D., Sawyer, W.H. and Schreiber, G., 1978. Thyroxine transport in choroid plexus. Journal of Biological Chemistry 262, 13907-13915.

Dietz, R., Riget, F. F., Sonne-Hansen, C., Letcher, R. J., Born, E. W., and Muir, D. C. G., 2004. Seasonal and temporal trends in polychlorinated biphenyls and organochlorine pesticides in East Greenland polar bears (Ursus maritimus), 19902001. The Science of the Total Environment 331, 107-124. 
Dietz, R., Riget, F. F., Sonne, C., Muir, D. C. G., Backus, S. M., Born, E. W., Kirkegaard, M., and Letcher, R. J., 2005. Seasonal trends and bioaccumulation of polybrominated diphenyl ethers in free-ranging East Greenland polar bears (Ursus maritimus). Environmental Pollution, in press.

Fisk, A.T., de Wit, C.A. Wayland, M., Kuzyk, Z.Z., Burgess, N., Letcher, R.J., Braune, B., Norstrom, R.J., Polischuk-Blum, S., Sandau, C.D., Lie, E. Jørgen, H., Larsen, S., Skaare, J.-U., Muir, D.C.G.; 2005. An assessment of the toxicological significance of anthropogenic contaminants in Canadian arctic wildlife. Science of the Total Environment 351-352, 57-93.

Flower, D.R., 1996. The lipocalin protein family: structure and function. Biochemical Journal 318, 1-14.

Gardner, A. M., Warren, V. L., Chen, J.-Y. T., and Mazzola, E. P., 1979. A metabolite of polybrominated biphenyls: its identification and decomposition to a brominated dibenzofuran in the gas chromatograph-mass spectrometer. Journal of Agricultural and Food Chemistry 27, 116-119.

Guvenius, D. M., Bergman, Å., and Norén, K., 2001. Polybrominated diphenyl ethers in Swedish human liver and adipose tissue. Archives of Environmental Contamination and Toxicology 40, 564-570.

Guvenius, D. M., Hassanzadeh, P., Bergman, A., and Norén, K., 2002. Metabolites of polychlorinated biphenyls in human liver and adipose tissue. Environmental Toxicology and Chemistry 21, 2264-2269.

Hakk, H., Larsen, G., Bergman, A., and Örn, U., 2002. Binding of brominated diphenyl ethers to male rat carrier proteins. Xenobiotica 32, 1079-1091.

Hakk, H. and Letcher, R. J., 2003. Metabolism in the toxicoknetics and fate of brominated flame retardants - a view. Environment International 29, 801-828.

Hamers, T., Kamstra, J.H., Sonneveld, E., Murk, A.J., Kester, M.H.A., Andersson, P.L., Legler, J., and Brouwer, A., 2006. In vitro profiling of the endocrine-disrupting potency of brominated flame retardants. Toxicological Sciences 92, 157-173.

Haraguchi, K., Kato, Y., Masuda, Y., and Kimura, R., 1997. Metabolism of 3,3',4,4'tetrachlorobiphenyl via sulphur-containing pathway in rat: liver-specific retention of methylsulphonyl metabolite. Xenobiotica 27, 831-842.

Haraguchi, K., Kato, Y., Koga, N., and Degawa, M., 2004. Metabolism of polychlorinated biphenyls by Gunn rats: identification and serum retention of catechol metabolites. Chemical Research in Toxicology 17, 1684-1691. 
Houde, M., Martin, J.W., Letcher, R.J., Solomon, K.R., Muir, D.C.G.; 2006. Environmental and biological monitoring of polyfluoroalkyl compounds: A critical review. Environmental Science and Technology 40, 3463-3473.

Isnansetyo, A. and Kamei, Y.,2003. MC21-A, a bactericidal antibiotic produced by e new marine bacterium, Pseudoalteromonas phenolica sp. nov. $\mathrm{O}-\mathrm{BC} 30^{\mathrm{T}}$, against methicillin-resistant Staphylococcus aureus substances. Antimicrobial Agents and Chemotherapy 47, 480-488..

Kannan, K., Yun, S. H., and Evans, T. J., 2005. Chlorinated, brominated, and perfluorinated contaminants in livers of polar bears from Alaska. Environmental Science and Technology 39, 9057-9063.

Käkelä, R., Hyvärinen, H., and Käkelä, A., 1997. Vitamines A1 (retinol, A2 (3,4didehydroretinol) and $\mathrm{E}$ ( $\alpha$-tocopheril) in the liver and blubber of lacustrine and marine ringed seals (Phoca hispida sp.). Comparative Biochemistry and Physiology 116B, 27-33.

Kirkegaard, M., Sonne, C., Leifsson, P.S., Dietz, R., Born, E.W., Muir, D.C.G., Letcher, R.J., 2005. Histology of selected immunological organs in polar bear (Ursus maritimus) from East Greenland in relation to levels of organohalogen contaminants. Science of the Total Environment 341, 119-132.

Kohli, J., Wyndham, C., Smylie, M., and Safe, S., 1978. Metabolism of bromobiphenyls. Biochemical Pharmacology 27, 1245-1249.

Koss, G., Weider, T., Seubert, S., and Seubert, A., 1994. 2,2',4,4',5,5'hexabromobiphenyl: its toxicokinetics, biotransformation and porphyrinogenic action in rats. Food and Chemical Toxicology 32, 605-610.

Kurihara, H., Mitani, T., Kawabata, J., Takahashi, K. 1999. Two new bromophenols from the red alga Odonthalia corymbifera. Journal of Natural Products, 62, 882-884.

Larsen, G. L., Bergman, A., Klasson-Wehler, E., and Bass, N. M., 1991. A methylsulfonyl metabolite of a polychlorinated biphenyl can serve as a ligand for fatty acid binding protein in rat intestinal mucosa. Chemico-Biological Interactions 77, 315-323.

Larsen, G. L., Huwe, J. K., Bergman, A., Klasson-Wehler, E., and Hargis, P., 1992. Methylsulfonyl metabolites of xenobiotics can serve as ligands for fatty acid binding proteins in chicken liver and intestinal mucosa. Chemosphere 25, 11891194. 
Letcher, R. J., Norstrom, R. J., and Bergman, A., 1995. Geographical distribution and identification of methyl sulphone PCB and DDE metabolites in pooled polar bear (Ursus maritimus) adipose tissue from the western hemisphere Arctic and Subarctic regions. The Science of the Total Environment 160/161, 409-420.

Letcher, R. J., Norstrom, R. J., Lin, S., Ramsay, M. A., and Bandiera, S. M., 1996. Immunoquantitation and microsomal monooxygenase activities of hepatic cytochromes P4501A and chlorinated hydrocarbon contaminant levels in Polar bear (Ursus maritimus). Toxicology and Applied Pharmacology 137, 127-140.

Letcher, R.J., Norstrom, R.J., Muir, D.C.G.; 1998. Biotransformation versus bioaccumulation: sources of methyl sulfone PCB and 4,4'-DDE metabolites in the polar bear food chain. Environmental Science and Technology 32, 1656-1661.

Letcher, R. J., Klasson-Whehler, E., and Bergman, Å., 2000. Methyl sulfone and hydroxylated metabolites of polychlorinated biphenyls. In: Paasivirta, J. (Ed.), The Handbook of Environmental Chemistry, vol. 3K, Springer-Verlag, Heidelberg, pp. 315-359.

Malmberg, T., Cenijn, P. H., Gutleb, A. C., and Bergman, Å., 2004. Methanol-water dissociation constants and relative transthyretin affinities for hydroxylated metabolites of PCB and PBDE congeners. Stockholm University, Stockholm, Sweden.

Marsh, G., Athanasiadou, M., Athanassiadis, I., Bergman, Å., Endo, T., and Haraguchi, K., 2005. Identification, quantification, and synthesis of a novel dimethoxylated polybrominated biphenyl in marine mammals caught of the coast of Japan. Environmental Science and Technology 39, 8684-8690.

Meerts, I.A.T.M., Hoving, S., Van den Berg, J.H.J., Weijers, B.M., Swarts, H.J., van der Beek, E.M., Bergman, A., Koeman, J.H., and Brouwer, A., 2004. Effects of In Utero exposure to 4-hydroxy-2,3,3',4',5-pentachlorobiphenyl (4-OH-CB107) on developmental landmarks, steroid hormone levels, and female estrous cyclicity in rats. Toxicological Sciences 82, 259-267.

Metcalfe, C., Metcalfe, T., Ray, S., Paterson, G., and Koenig, B., 1999. Polychlorinated biphenyls and oranochlorine compounds in brain, liver and muscle of beluga whales (Delphinapterus leucas) from the Arctic and St. Lawrence estuary. Marine Environmental Research 47, 1-15.

Muir, D.C.G., Norstrom, R.J., Simon, M., 1988. Organochlorine contaminants in Arctic marine food chains: Accumulation of specific PCB congeners and chlordanerelated compounds. Environmental Science and Technology 22, 1071-1079. 
Muir, D. C. G., Backus, S. M., Derocher, A. E., Dietz, R., Evans, T., Gabrielsen, G. W., Nagy, J., Norstrom, R. J., Sonne, C., Stirling, I., Taylor, M. K., and Letcher, R. J., 2006. Brominated flame retardants in polar bears (Ursus maritimus) from Alaska, the Canadian Arctic, Greenland, and Svalbard. Environmental Science and Technology 40, 449-455.

Norstrom, R. J., Belikov, S. E., Born, E. W., Garner, G. W., Malone, B., Olpinski, S., Ramsay, M. A., Schliebe, S., Stirling, I., Stishov, M. S., Taylor, M. K., and Wiig, O., 1998. Chlorinated hydrocarbon contaminants in polar bears from Eastern Russia, North America, Greenlang, and Svalbard: biomonitoring of Artic pollution. Archives of Environmental Contamination and Toxicology 35, 354367.

Oehme, M., Biseth, A., Schlabach, M., and Wiig, Ø., 1995. Concentrations of polychlorinated dibenzo-p-dioxins, dibenzofurans and non-ortho substituted biphenyls in polar bear milk from Svalbard (Norway). Environmental Pollution 90, 401-407.

Ohta, C., Haraguchi, K., Kato, Y., and Koga, N., 2005. In vitro metabolism of 2,2',3,4',5,5',6-heptachlorobiphenyl (CB187) by liver microsomes from rats, hamsters and guinea pigs. Xenobiotica 35, 319-330.

Padmanabhan, J., Parthasarathi, R., Subramanian, V., and Chattaraj, P. K., 2006. QSPR models for polychlorinated biphenyls: $n$-octanol/water partition coefficients. Bioorganic and Medicinal Chemistry 14, 1021-1028.

Palha, J. A., 2002. Transthyretin as a thyroid hormone carrier: function revised. Clinical Chemistry and Laboratory Medicine 40, 1292-1300.

Peck, A. M., Tuerk, K. J. S., Keller, J., Kucklick, J. R., and Schantz, M. M., 2005. Hexabromocyclododecane diasteromers in enantiomers in white-sided dophin blubber and liver tissue. Organohalogen Compounds 2005, 1259-1262.

Polischuk, S.C., Letcher, R.J., Norstrom, R.J., Ramsay, M.A., 1995. Preliminary results of fasting on the kinetics of organochlorines in polar bear (Ursus maritimus). Science of the Total Environment 160, 465-472.

Polischuk, S.C., Norstrom, R.J., Ramsay, M.A., 2002. Body burdens and tissue concentrations of organochlorines in polar bears (Ursus maritimus) vary during seasonal fasts. Environmental Pollution 118, 29-39.

Prothero, J. W., 1980. Scaling of blood parameters in mammals. Comparative Biochemistry and Physiology 67A, 649-657.

Prothero, J. W., 1982. Organ scaling in mammals: the liver. Comparative Biochemistry and Physiology 71A, 567-577. 
Renner, G., 1988. Hexachlorobenzene and its metabolism. Toxicological and Environmental Chemistry 18, 51-78.

Sandala, G. M., Sonne-Hansen, C., Dietz, R., Muir, D. C. G., Valters, K., Bennett, E. R., Born, E. W., and Letcher, R. J., 2004. Hydroxylated and methyl sulfone PCB metabolites in adipose and whole blood of polar bear (Ursus maritimus) from east Greenland. The Science of the Total Environment 331, 125-141.

Sandau, C. D., Meerts, I. A. T. M., Letcher, R. J., McAlees, A. J., Chittim, B., Brouwer, A., and Norstrom, R. J., 2000a. Identification of 4-hydroxyheptachlorostyrene in polar bear plasma and its binding affinity to transthyretin: a metabolite of octachlorostyrene. Environmental Science and Technology 34, 3871-3877.

Sandau, C. D.,2000b. Analytical chemistry of hydroxylated metabolites of PCBs and other halogenated phenolic compounds in blood and their relationship to thyroid hormone and retinol homeostasis in humans and polar bears. Carleton University, Ottawa, Canada.

Schreiber, G., Richardson, S.J. and Prapunpoj, O., 2001. Structure and expression of the transthyretin gene in the coroid plexus: a model for the study of the mechanism of evolution. Microscopy Research and Technique 52, 21-30.

Sharma,R. and Kodavanti,P.R.S., 2002. In vitro effects of polychlorinated biphenyls and hydroxy metabolites on nitric oxide synthases in rat brain. Toxicology and Applied Pharmacology 178, 127-136.

Skaare,J.U., Bernhoft,A., Wiig,Ø., Norum,K.R., Haug,E., Eide,D.M., Derocher,A.E., 2001. Relationship between plasma levels of organochlorines, retinol and thyroid hormones from polar bears (Ursus maritimus) at Svalbard. Journal of Toxicology and Environmental Health Part A 62, 227-241.

Smithwick, M.M., Mabury, S.A., Solomon, K.R., Sonne, C., Martin, J.W., Born, E.W., Dietz, R., Derocher, A.E., Letcher, R.J., Evans, T.J., Gabrielsen, G.W., Nagy, J., Stirling, I., Taylor, M.K., Muir, D.C.G; 2005. Circumpolar study of perfluoroalkyl contaminants in polar bears (Ursus maritimus). Environmental Science and Technology 39, 5517-5523.

Sonne, C., Dietz, R., Leifsson, P.S., Born, E.W., Kirkegaard, M., Letcher, R.J., Muir, D.C.G., Riget, F.F., Hyldstrup, L., 2006. Are organohalogen contaminants a cofactor in the development of renal lesions in East Greenland polar bears (Ursus maritimus)? Environmental Toxicology and Chemistry 25, 1551-1557.

Sørmo, E. G., Salmer, M. P., Jenssen, B. M., Hop, H., Bæk, K., Kovacs, K. M., Lydersen, C., Falk-Petersen, S., Gabrielsen, G. W., Lie, E., and Skaare, J. U., 2006. Biomagnification of brominated flame retardants in the polar bear food chain in Svalbard, Norway. Environmental Toxicology and Chemistry, 25, 2502-2511. 
Takasuga, T., Senthilkumar, K., Watanabe, K., Takemori, H., Shoda, T. and Kuroda, Y., 2004. Ultratrace analysis of polychlorinated biphenyls (PCBs) and their hydroxylated metabolites (OH-PCBs) in human serum and cerebrospinal fluid (CSF) samples. Organohalogen Compounds 66, 2529-2534.

Teuten, E. L., Xu, L., and Reddy, C. M., 2005. Two abundant bioaccumulated halogenated compounds are natural products. Science 307, 917-920.

Tilbury, K. L., Stein, J. E., Meador, J. P., Krone, C. A., and Chan, S.-L., 1997. Chemical contaminants in harbor porpoise (Phocoena Phocoena) from the north atlantic coast: tissue concentrations and intra- and inter- organ distribution. Chemosphere $34,2159-2181$.

Verreault, J., Muir, D. C. G., Norstrom, R. J., Stirling, I., Fisk, A. T., Gabrielsen, G. W., Derocher, A. E., Evans, T. J., Dietz, R., Sonne, C., Sandala, G. M., Gebbink, W. A., Taylor, M. K., Nagy, J., and Letcher, R. J., 2005a. Chlorinated hydrocarbon contaminants and metabolites in polar bear (Ursus maritimus) from Alaska, Canada, East Greenland, and Svalbard: 1996-2002. The Science of the Total Environment 351-352, 369-390.

Verreault, J., Gabrielsen, G. W., Chu, S., Muir, D. C. G., Andersen, M., Hamaed, A., and Letcher, R. J., 2005b. Flame retardants and methoxylated and hydroxylated polybrominated diphenyl ethers in two Norwegian Arctic top predators: glaucous gulls and polar bears. Environmental Science and Technology 39, 6021-6028.

Verreault, J., Norstrom, R.J., Ramsay, M.A., Mulvihill, M., Letcher, R.J., 2006. Composition of chlorinated hydrocarbon contaminants among major adipose tissue depots of polar bear (Ursus Maritimus) from the Canadian High Arctic. Science of the Total Environment, in press.

Vetter, W., Stoll, E., Garson, M. J., Fahey, S. J., Gaus, C., and Müller, J. F., 2002. Sponge halogenated natural products found at parts-per-million levels in marine mammals. Environmental Toxicology and Chemistry 21, 2014-2019.

Wiberg, K., Letcher, R. J., Sandau, C. D., Norstrom, R. J., Tysklind, M., and Bidleman, T. F., 2000. The enantioselective bioaccumulation of chiral chlordane and $\alpha-\mathrm{HCH}$ contaminants in the polar bear food chain. Environmental Science and Technology 34, 2668-2674.

Wolkers, H., Bavel, B. v., Derocher, A. E., Wiig, Ø., Kovacs, K. M., Lydersen, C., and Lindström, G., 2004. Congener-specific accumulation and food chain transfer of polybrominated diphenyl ethers in two arctic food chains. Environmental Science and Technology $38,1667-1674$. 
Wolkers, H., Hammill, M. O., and Van Bavel, B., 2006. Tissue-specific accumulation and lactational transfer of polychlorinated biphenyls, chlorinated pesticides, and brominated flame retardants in hooded seals (Cistophora cristata) from the Gulf of St. Lawrence: applications for monitoring. Environmental Pollution 142, 476486.

Yen, P.M., 2001. Physiological and molecular basis of thyroid hormone action. Physiological Reviews 81, 1097-1135.

Zegers, B.N, Mets, A., Van Bommel, R., Minkenberg, C., Hamers, T., Kamstra, J.H., Poerce, G.J., Boon, J.P., 2005. Levels of hexabromocyclododecanes in harbour porpoises and common dolphins from western European seas, with evidence for stereoisomer-specific biotransformation by cytochrome P450. Environmental Science and technology 39, 2095-2100. 


\section{CHAPTER 4}

\section{Bioaccumulation and Biotransformation of Brominated and Chlorinated}

\section{Organohalogens and By-Products from Ringed Seals to Polar Bears from East}

\section{Greenland $^{\dagger}$}

\subsection{Introduction}

Polar bears (Ursus maritimus) from the East Greenland area of the Arctic are apical predators in the marine food web and have been documented to accumulate some of the highest levels of known brominated and chlorinated organohalogen pollutants [PCBs, OC pesticides, and brominated flame retardants (BFRs) such as polybrominated diphenyl ethers (PBDEs) and hexabromocyclododecanes (HBCDs)] in their fat tissue and/or blood relative to animals from other circumpolar populations (Norstrom et al., 1998; Verreault et al., 2005a; Muir et al., 2006).

It is commonly believed that polar bears feed predominantly on ringed seals (Phoca hispida), and specifically the blubber, although polar bears have been reported to consume bearded seals (Erignathus barbatus) (Stirling and Archibald, 1977; Smith, 1980). Opportunistic feeding on other species such as beluga whales (Delphinaterus lerucas) and narwhales (Monodon monoceros) has also been documented for polar bears (Smith et al., 1990; Derocher et al., 1993, 2000). However, ringed seal (blubber) has been reported to account for $\geq 98 \%$ of the diet of polar bears in the Beaufort Sea. In the early 1990s in western Hudson Bay, ringed seals accounted for about $80 \%$ of the bears' intake in the early 1990s, indicating the importance of foraging in ice-covered habitat.

${ }^{\dagger}$ Gebbink et al. 2006. Environmental Science and Technology In preparation for submission. 
Recently, Iverson et al. (2006) reported that ringed seal consumption by polar bears declined throughout the 1990 s concurrent with progressively earlier ice breakup, while the proportions of bearded and harbour seals increased, suggesting reduced reliance on ice. Regardless, Iverson et al. (2006) used fatty acid signatures as indicators of diet and found that, in both northern and southern Beaufort Bay areas, ringed seals comprised about $95 \%$ of the fatty acid signatures of polar bear adipose tissue and the remainder being made up by bearded seals. Therefore, in general, it appears that ringed seal blubber is highly representative of the polar bear diet.

The bioaccumulation of an organohalogen is defined as the degree to which an organism takes up and retains contaminants from all applicable exposure routes. Biomagnification refers to the tendency of the contaminants to become increasingly concentrated at successively higher trophic levels of a food chain or food web. The bioaccumulation of organohalogens classified as legacy POPs (e.g., PCBs, several classes of organochlorine pesticides, and degradation by-products) have been studied in ringed seal blubber relative to polar bear fat (Muir et al., 1988; Letcher et al., 1998; Kucklick et al., 2002). Among the organohalogen classes that are classified as being of emerging importance in the Arctic, $\mathrm{MeSO}_{2}$-PCBs and $\mathrm{MeSO}_{2}$-DDE have been found to be formed in both ringed seals and polar bears from PCB and $p, p^{\prime}$-DDE precursors, respectively, and have also been shown to accumulate from ringed seals to polar bears (Letcher et al., 1998). For $\Sigma-$ $\mathrm{MeSO}_{2}-\mathrm{PCB}$, the BAF from ringed seal blubber to polar bear fat from a study on Resolute Bay area animals was calculated to be 27.8 , which is comparable to that of $\Sigma-$ PCB with a BAF of 15.1 (Letcher et al., 1998). Muir et al. (2006) recently reported that 
for circumpolar populations of bears, the biomagnification (or bioaccumulation) factors (from seal blubber) for individual BDE congeners ranged from 0.2 to 130 . For East Greenland bears, using ringed seal blubber data from Vorkamp et al. (2004a), the BAFs reported for individual BDE congeners ranged from 0.2 to 82 (Muir et al., 2006). A recent study on PBDEs in Svalbard polar bears and ringed seals showed a contrast in BAFs for individual BDE congeners, which ranged from 0.1 to 4.2 (Sørmo et al., 2006).

Apart from the studies already mentioned, prey (ringed seal) to predator (polar bear) bioaccumulation is largely unknown for many emerging chlorinated and brominated POPs that have been recently identified in polar bears, especially those of the phenolic variety (Sandau et al., 2000; Sandala et al., 2004; Braune et al., 2005; Verreault et al., 2005a). This includes virtually all of the organohalogens that were newly identified and characterized in tissues of East Greenland polar bears as detailed in Chapter 3. The phenolic contaminants such as hydroxylated (OH) PCBs, OH-PBDEs, PCP, 4-OH-HpCS and OH-PBBs identified (mainly in the blood) in the present bears and in other species have been shown to possess lipophilic characteristics (i.e., $\log K_{\mathrm{OW}}$ of $\mathrm{OH}-\mathrm{PCBs}$ ranged from 5.9 to 7.2 ) (Malmberg, 2004). To our knowledge, nothing is known about the relative importance of metabolic formation from precursor organohalogens versus accumulation from the diet.

Given the present dearth of information and study, the objective of the present study is to assess the tissue-specific bioaccumulation and potential biomagnification of various, and 
recently identified (see Chapter 3), chlorinated and brominated contaminants from ringed seal blubber to polar bear tissues from East Greenland.

\subsection{Results \& Discussion}

\subsubsection{Organohalogens in ringed seals}

Polar bears are the top-level carnivore in the Arctic marine food chain and are opportunistic feeders, consuming bearded seal, beluga whale, walrus and bowhead whale carcasses, but have a large reliance on ringed seals (Stirling and Archibald, 1977; Smith, 1980; Derocher et al., 2000; Kucklick et al., 2002). The POPs have lipophilic properties and thus preferentially accumulate in the blubber of seals. Polar bears are exposed to large amounts of POPs when they ingest a sizable portion of the seals body. Levels and patterns of the POPs such as PCBs, $\mathrm{MeSO}_{2}-\mathrm{PCBs}, \mathrm{OC}$ pesticides, and PBDEs have been studied in ringed seal blubber from Alaskan, Canadian, Greenland and Svalbard populations (Letcher et al., 1998; Wolkers et al., 1998; Ikonomou et al., 2002; Kucklick et al., 2002; Vorkamp et al., 2004a, 2004b). The levels and patterns of other BFRs [total$(\alpha)-\mathrm{HBCD}, \mathrm{PBBs}]$ and metabolites and/or degradation products (OH-PCBs, 4-OH-HpCS, PCP, OH-PBDEs and MeO-PBDEs) are virtually unstudied.

The diet of the polar bears in this study is represented by the blubber of six female and nine male ringed seals (age 1.5 - 11.5) that were collected in East Greenland in 2002. Although the precise results are described in the following subsection, in general there was no significant difference $(p>0.09)$ in the levels among the sums of the individual POP classes in the blubber of male versus female ringed seals. Therefore, male and 
female ringed seals were viewed as a single sample set and were viewed of being representative of the diet of the East Greenland polar bears with respect to assessments of organohalogen bioaccumulation and potential biomagnification.

\subsubsection{PCBs and PCB Metabolites}

The mean $\Sigma$-PCB concentration found in the ringed seal blubber was $709 \pm 74 \mathrm{ng} / \mathrm{g}$ lipid wt (Table 4.1), which was comparable to $\Sigma$-PCB levels found in an earlier study on ringed seals collected in 2001 from East Greenland (Vorkamp et al., 2004a). Besides the dominant PCB congeners that were found in the polar bear tissues, several other (mainly lower chlorinated) PCBs were detected in the ringed seal blubber (Figure 4.1). This pattern was also seen in ringed seals collected from Svalbard (Wolkers et al., 1998).

To our knowledge, $\mathrm{OH}-\mathrm{PCB}$ have only been previously determined and detected in the blood of ringed seals (from the Canadian Arctic in 1999) at low $\Sigma$-OH-PCB concentrations, $<0.4 \mathrm{ng} / \mathrm{g}$ wet wt (Sandau et al., 2000). Also to our knowledge, there is no published data on OH-PCBs in ringed seal blubber or seal blubber from any species or geographic location. In the present study, in the blubber of East Greenland ringed seals OH-PCBs were below detection limits $(<0.1 \mathrm{ng} / \mathrm{g}$ lipid wt). The fact that the PCB pattern in the ringed seal blubber has more congeners compared to the polar bear tissues and that no $\mathrm{OH}-\mathrm{PCBs}$ were detected in the blubber indicate that ringed seals have: 1) a poor capacity or slow rate to metabolize PCB precursors to OH-PCBs; 2) a high capacity or high rate of Phase II processes to conjugate $\mathrm{OH}-\mathrm{PCBs}$; and/or 3) a preferential accumulation of OH-PCBs in other tissues, not the blubber (ie., blood). 
Table 4.1. The mean $( \pm \mathrm{SE})$ of concentrations of classes of neutral and phenolic organohalogen compounds in the blubber of male and female ringed seals from East Greenland $(\mathrm{n}=15)$.

\begin{tabular}{|c|c|c|}
\hline Analyte & Mean $( \pm$ SE) & No. Samples > MLOQ \\
\hline Lipid (\%) & $98 \pm 1$ & \\
\hline$\Sigma-\mathrm{PCB}^{\mathrm{a}}$ & $709 \pm 74$ & 15 \\
\hline$\Sigma-\mathrm{OH}-\mathrm{PCB}^{\mathrm{b}}$ & n.d. & 0 \\
\hline$\Sigma-\mathrm{MeSO}_{2}-\mathrm{PCB}^{\mathrm{a}}$ & $35 \pm 5$ & 15 \\
\hline$\Sigma-\mathrm{CHL}^{\mathrm{a}}$ & $241 \pm 40$ & 15 \\
\hline$\Sigma-$ DDT $^{\mathrm{a}}$ & $602 \pm 75$ & 15 \\
\hline 3- $\mathrm{MeSO}_{2}-p, \mathrm{p}^{\prime}-\mathrm{DDE}^{\mathrm{a}}$ & $1.5 \pm 0.4$ & 11 \\
\hline 4-OH-HpCS & n.d. & 0 \\
\hline $\mathrm{PCP}^{\mathrm{b}}$ & $1.0 \pm 0.3$ & 15 \\
\hline$\sum-\mathrm{PBDE}^{\mathrm{a}}$ & $298 \pm 127$ & 15 \\
\hline Total- $(\alpha)-H B C D^{a}$ & $37 \pm 3$ & 15 \\
\hline$\Sigma-\mathrm{PBB}^{\mathrm{a}}$ & $0.5 \pm 0.2$ & 9 \\
\hline$\Sigma$-OH-PBDE ${ }^{\mathrm{b}}$ & $0.7 \pm 0.5$ & 6 \\
\hline$\Sigma$-MeO-PBDE ${ }^{\mathrm{b}}$ & $7.0 \pm 1.4$ & 15 \\
\hline$\Sigma$-OH-PBB & $0.5 \pm 0.3$ & 12 \\
\hline
\end{tabular}

${ }^{\mathrm{a}} \mathrm{ng} / \mathrm{g}$ lipid wt, lipid associated

${ }^{b} \mathrm{ng} / \mathrm{g}$ wet $\mathrm{wt}$, protein associated n.d. - not detected 
The mean $\Sigma-\mathrm{MeSO}_{2}-\mathrm{PCB}$ concentrations was $35 \pm 5 \mathrm{ng} / \mathrm{g}$ lipid wt in the ringed seal blubber (Table 4.1), which were comparable with $\Sigma-\mathrm{MeSO}_{2}-\mathrm{PCB}$ concentrations in the blubber of ringed seals from the Canadian Arctic (Letcher et al., 1998). The $\mathrm{MeSO}_{2}-\mathrm{PCB}$ congener pattern in the seal blubber was similar to the $\mathrm{MeSO}_{2}-\mathrm{PCB}$ congener pattern in the East Greenland polar bear tissues (Figure 4.2), and similar to the congener pattern reported in the ringed seals and polar bears from the Canadian Arctic (Letcher et al., 1998). The finding of $\mathrm{PCBs}$ and $\mathrm{MeSO}_{2}-\mathrm{PCBs}$ in the ringed seal blubber indicated the bioaccumulation of these organohalogen contaminants from ringed seals to polar bears.

\subsubsection{Chlorinated Metabolites and Phenolics}

The 3-MeSO $2-p, p^{\prime}-\mathrm{DDE}$, a metabolite of $p, p^{\prime}-\mathrm{DDE}$, was detected in ringed seal blubber and found at levels that were comparable to $3-\mathrm{MeSO}_{2}-p, p^{\prime}-\mathrm{DDE}$ concentrations in Canadian ringed seals (Table 4.1) (Letcher et al., 1998). Letcher et al. (1998) reported that ringed seals are capable of metabolizing $p, p^{\prime}-\mathrm{DDE}$ to $3-\mathrm{MeSO}_{2}-p, p^{\prime}-\mathrm{DDE}$.

The 4-OH-HpCS, a metabolite of octachlorostyrene (OCS), was not detected in ringed seal blubber $(<0.01 \mathrm{ng} / \mathrm{g}$ wet $\mathrm{wt})$. In ringed seal plasma the 4-OH-HpCS concentration was shown to be 3 orders of magnitude lower than the concentration in polar bear plasma (Sandau et al., 2000). As seen with the absence of OH-PCBs in ringed seal blubber, the seal appear to have a lower capacity to metabolize OCS compared to polar bears. The selectivity to retain 4-OH-HpCS in the blood over the blubber may have resulted in none detectable levels of 4-OH-HpCS in the blubber. 
Pentachlorophenol (PCP) was detected in ringed seal blubber at a mean concentration of $1.0 \pm 0.3 \mathrm{ng} / \mathrm{g}$ wet wt. There can be two possible sources of PCP contamination; PCP was used as a pesticide and it can also be formed by the metabolism of hexachlorobenzene (Renner, 1988). Although the exact source of the detected PCP in polar bears is not clear, the accumulation of the pesticide from ringed seal blubber seems to be the explicable source. From the present findings, East Greenland ringed seals seem to have a lower capacity in general to form oxidative metabolites from organohalogen pollutants (i.e., OH-PCBs and 4-OH-HpCS).

\subsubsection{Brominated compounds}

The mean $\Sigma$-PBDE concentration in ringed seal blubber was $298 \pm 127 \mathrm{ng} / \mathrm{g}$ lipid wt. This concentration was higher compared to previous studies on East Greenland ringed seals collected in 2001 (Vorkamp et al., 2004a). The PBDE congener pattern in ringed seal blubber found in this study was comparable to the congener pattern found earlier in East Greenland and Canadian seals, as well as to the polar bear congener pattern, with BDE-47 and -99 as the dominant congeners (Ikonomou et al., 2002; Vorkamp et al., 2004a) (Figure 4.3). Total-( $\alpha$ )-HBCD and BB-101 were detected at $37 \pm 3 \mathrm{ng} / \mathrm{g} \mathrm{lipid} \mathrm{wt}$ and $0.5 \pm 0.2 \mathrm{ng} / \mathrm{g}$ lipid wt, respectively. Comparable total-( $\alpha)$-HBCD levels were found in Svalbard ringed seals captured in 2003 (Sørmo et al., 2006); however, PBBs have previously not been reported in ringed seal tissues from any population.

Only one OH-PBDE congener was detected in the seal blubber, 6-OH-BDE47 at a mean concentration of $0.7 \pm 0.5 \mathrm{ng} / \mathrm{g}$ wet wt. The 6-OH-BDE47 congener has been identified 
as a natural product that is produced by Dysidea sponges (Carté et al., 1981; Fu et al., 1996). It has also been detected in several trophic levels in the marine food chain (Malmvärn et al., 2005). The 6-OH-BDE congener is most likely of a natural source, as the capacity of ringed seals towards oxidative metabolism of PBDEs is likely to be low, as exemplified by the low levels of $\mathrm{OH}-\mathrm{PCBs}$ and 4-OH-HpCS in ringed seal blubber or plasma (Sandau et al., 2000).

In the ringed seal blubber three MeO-PBDE congeners were detected: 6-MeO-BDE47, 2'-MeO-BDE68, and 6-MeO-BDE85 (Table 4.1). The 6-MeO-BDE47 and 2'-MeOBDE68 congeners were identified as natural products produced by marine sponges (Malmvärn et al., 2005), are ortho-MeO-substituted, and have been found to accumulate and biomagnify in marine mammals food chains (Teuten et al., 2005). The 6-MeOBDE85 congener, was also ortho-MeO-substituted and it was thus hypothesized to be of natural origin, since all identified natural $\mathrm{OH}-$ and $\mathrm{MeO}-\mathrm{PBDEs}$ are ortho-OH/MeOsubstituted. The MeO-PBDE congener pattern in the seal blubber relative to the polar bear tissues showed that two of the three congeners (i.e., 6-MeO-BDE47 and 6-MeOBDE85) were detected in the bear tissues (Figure 4.4). MeO-PBDEs have previously been found in the blubber of ringed seals from the Baltic Sea (Haglund et al., 1997).

The three unidentified OH-PBB congeners, one tri-brominated and two tetra-brominated OH-PBBs, were detected in the seal blubber (for identification of unknowns see Chapter 3.2.2.3.). Like $\mathrm{OH}-\mathrm{PBDEs}$, the source of $\mathrm{OH}-\mathrm{PBBs}$ is unclear; they may be formed by oxidative metabolism of PBBs and/or are the result of accumulated, natural marine 
products. A di-OH-PBB (2,2'-diOH-BB80) has been identified as a natural product (Isnansetyo et al., 2003), the methylated derivative, also believed to be of natural origin, was detected in several dolphin and whale species near the coast of Japan (Marsh et al., 2005). To our knowledge this is the first report on OH-PBBs in the tissues of any Arctic marine mammal.

\subsubsection{Legacy organochlorine POPs}

In the blubber of East Greenland ringed seals, $\Sigma$-DDT and $\Sigma$-CHL were at the highest concentrations among $\mathrm{OC}$ pesticide classes in comparison to, for example, $\Sigma-\mathrm{HCH}$ and HCB (Table 4.1). Mean levels of $\Sigma$-DDT and $\Sigma$-CHL were $602 \pm 75 \mathrm{ng} / \mathrm{g} / \mathrm{w}$ and $241 \pm$ $40 \mathrm{ng} / \mathrm{g}$ lw, respectively, and were found to be comparable to the levels in the blubber of East Greenland ringed seals sampled in 2001 (Vorkamp et al., 2004a). Concentrations of the legacy POPs were found to be higher relative to the concentrations of the emerging POPs, with the exception of $\Sigma$-PBDE. The concentrations of $\Sigma$-PBDE were at levels comparable to those of $\Sigma$-DDT.

\subsubsection{Bioaccumulation and Biomagnification Potential}

The ringed seal assessment showed that for East Greenland polar bears, the seal blubber is a potential accumulative source of PCBs, DDTs, CHLs, $\mathrm{MeSO}_{2}-\mathrm{PCBs}, 3-\mathrm{MeSO}_{2}-p, p$ 'DDE, PCP, PBDEs, BB-101, total-( $\alpha$ )-HBCD, OH-PBDEs, MeO-PBDEs and OH-PBBs, and thus these contaminants have bioaccummulation and biomagnification potential. 
The bioaccumulation of legacy POPs (PCBs and OC pesticides) as well as some emerging POPs [e.g., PBDEs, total-( $\alpha)-\mathrm{HBCD}$ and $\mathrm{MeSO}_{2}-\mathrm{PCBs}$ ] have been well studied from ringed seal blubber to polar bear fat amongst several populations in the western hemisphere (Muir et al., 1988, 2006; Letcher et al., 1998; Wiberg et al., 2000; Kucklick et al., 2002; Sørmo et al, 2006). Information on the bioaccumulation of, specifically, phenolic compounds from ringed seal blubber to polar bear fat, and the bioaccumulation of these POPs to with respect to tissue-specificity in polar bears (blood, brain and liver) has, to our knowledge, not been studied. BAFs (concentration in predator tissue / concentration in prey tissue) that are $>1$ indicate biomagnification, and can be described as a biomagnifications factors (BMFs), assuming that the prey is fully representative of the predators diet. In the case of apparent organohalogen metabolites, a BAF of $>1$ can also indicate that there is a potential a dietary accumulation as well as a metabolic formation source in the predator. BAFs of $<1$ indicate that the rate of metabolism/elimination is greater than the rate of uptake. Such a BAF/BMF approach was described for $\mathrm{MeSO}_{2}-\mathrm{PCBs}$ in ringed seal to polar bears from the Canadian high Arctic (Letcher et al., 1998).

\subsubsection{PCBs and PCB Metabolites}

In Chapter 3 we showed that there were sex-specific differences for $\mathrm{PCBs}, \mathrm{MeSO}_{2}-\mathrm{PCBs}$ and the 3- $\mathrm{MeSO}_{2}-p, p^{\prime}-\mathrm{DDE}$ in East Greenland polar bears, and therefore tissue-specific BAFs were calculated for both the male and female polar bears separately using ringed seals (males and females) as a single sample set. The present results showed that the BAFs for $\Sigma$-PCB in male polar bears were significantly $(p<0.05)$ higher in the fat, brain 
and liver relative to BAFs in the corresponding female tissues (Table 4.2.). This sex related difference was previously not seen as earlier studies were carried out using either one sex or pooled samples (Muir et al., 1988; Letcher et al., 1998; Kucklick et al., 2002). The BAF of PCBs in polar bear fat in the present study was found to be comparable to the BAF of PCBs in the fat of Canadian polar bears (Muir et al., 1988; Letcher et al., 1998). The BAF in the liver was significantly $(p<0.0002)$ higher than in any other tissue (Table 4.2.). The highest BAF amongst the tissues was found in the liver. This was a consequence of the apparent specific protein binding of PCBs in the liver. The BAF for PCBs in male and female polar bear tissues, with the exception in the female brain, were all $>1$. Even though biotransformation of PCBs takes place in the polar bear, the rate of biotransformation to $\mathrm{OH}-\mathrm{PCBs}$ is much lower than the rate of PCB uptake through the polar bears diet.

The BAFs for $\Sigma-\mathrm{MeSO}_{2}$-PCB in male polar bear fat, brain and liver were significantly $(p<0.05)$ higher compared to those tissues in female polar bears (Table 4.2$)$. The BAFs for the four tissues in both males and females were all $>1$ and were significantly $(p<0.007)$ different from each other, with the exception of the BAF for female fat and blood which were not significantly different from each other $(p>0.05)$. The BAFs for $\Sigma$ $\mathrm{MeSO}_{2}-\mathrm{PCB}$ in the fat and liver for males and females were the similar compared to the BAFs of fat and liver of Canadian polar bears (Letcher et al., 1998). Aside from the bioaccumulation of $\mathrm{MeSO}_{2}-\mathrm{PCBs}$ from the seal blubber to the polar bear, another source of $\mathrm{MeSO}_{2}-\mathrm{PCBs}$ is the biotransformation of $\mathrm{PCBs}$ to $\mathrm{MeSO}_{2}-\mathrm{PCBs}$ by the polar bear. Letcher et al. (1998) concluded that in the polar bear food chain in the Canadian Arctic, 
Table 4.2. Bioaccumulation factors ${ }^{a}( \pm \mathrm{SE})$ of classes of neutral organohalogen compounds from ringed seals to male and female polar bears from East Greenland.

\begin{tabular}{|c|c|c|c|c|c|}
\hline Sex & Analyte & $\begin{array}{c}\text { Fat } \\
\text { Mean }( \pm \mathrm{SE})\end{array}$ & $\begin{array}{c}\text { Blood } \\
\text { Mean }( \pm \mathrm{SE})\end{array}$ & $\begin{array}{c}\text { Brain } \\
\text { Mean }( \pm \text { SE })\end{array}$ & $\begin{array}{c}\text { Liver } \\
\text { Mean }( \pm \mathrm{SE})\end{array}$ \\
\hline $\begin{array}{l}\text { Female } \\
(n=10)\end{array}$ & $\begin{array}{l}\Sigma-\mathrm{PCB} \\
\Sigma-\mathrm{MeSO}_{2}-\mathrm{PCB} \\
\mathrm{MeSO}_{2}-\mathrm{DDE}\end{array}$ & $\begin{array}{l}7.4 \pm 1.0^{\mathrm{b}} \\
7.2 \pm 1.7^{\mathrm{b}} \\
4.8 \pm 1.2^{\mathrm{b}}\end{array}$ & $\begin{array}{l}3.2 \pm 0.6 \\
7.8 \pm 1.5 \\
5.1 \pm 1.6\end{array}$ & $\begin{array}{c}0.4 \pm 0.1^{\mathrm{b}} \\
1.8 \pm 0.3^{\mathrm{b}} \\
-\end{array}$ & $\begin{array}{c}32 \pm 4^{\mathrm{b}} \\
34 \pm 10^{\mathrm{b}} \\
198 \pm 34^{\mathrm{b}}\end{array}$ \\
\hline $\begin{array}{l}\text { Male } \\
(n=10)\end{array}$ & $\begin{array}{l}\Sigma-\mathrm{PCB} \\
\Sigma-\mathrm{MeSO}_{2}-\mathrm{PCB} \\
\mathrm{MeSO}_{2}-\mathrm{DDE}\end{array}$ & $\begin{array}{c}12 \pm 2^{b} \\
26 \pm 9^{b} \\
25 \pm 16^{b} \\
\end{array}$ & $\begin{array}{c}6.3 \pm 2.2 \\
23 \pm 11 \\
11 \pm 3 \\
\end{array}$ & $\begin{array}{c}1.3 \pm 0.3^{b} \\
1.1 \pm 0.3^{b} \\
-\end{array}$ & $\begin{array}{c}53 \pm 9^{\mathrm{b}} \\
95 \pm 34^{\mathrm{b}} \\
570 \pm 137^{\mathrm{b}} \\
\end{array}$ \\
\hline
\end{tabular}

${ }^{a}$ BAFs were calculated on a lipid wt basis

${ }^{\mathrm{b}}$ BAFs in male polar bear tissues were significantly higher than in female polar bear tissues $(p<0.05)$ 
Table 4.3. Bioaccumulation factors $( \pm \mathrm{SE}$ ) of classes of neutral and phenolic organohalogen compounds from ringed seals to polar bears from East Greenland $(n=20)$.

\begin{tabular}{|c|c|c|c|c|}
\hline Analyte & $\begin{array}{c}\text { Fat } \\
\text { Mean }( \pm \mathrm{SE})\end{array}$ & $\begin{array}{c}\text { Blood } \\
\text { Mean }( \pm \mathrm{SE})\end{array}$ & $\begin{array}{c}\text { Brain } \\
\text { Mean }( \pm \mathrm{SE})\end{array}$ & $\begin{array}{c}\text { Liver } \\
\text { Mean }( \pm \mathrm{SE}) \\
\end{array}$ \\
\hline$\Sigma-\mathrm{CHL}^{\mathrm{a}}$ & $6.2 \pm 0.8$ & $2.3 \pm 0.4$ & $0.3 \pm 0.1$ & $184 \pm 41$ \\
\hline$\Sigma$-DDT ${ }^{\mathrm{a}}$ & $0.8 \pm 0.1$ & $3.0 \pm 1.3$ & $0.05 \pm 0.06$ & $4.1 \pm 1.5$ \\
\hline$\Sigma-\mathrm{OH}-\mathrm{PCB}^{\mathrm{b}}$ & - & - & - & - \\
\hline 4-OH-HpCS ${ }^{b}$ & - & - & - & - \\
\hline $\mathrm{PCP}^{\mathrm{b}}$ & $1.4 \pm 0.7$ & $0.10 \pm 0.04$ & $0.22 \pm 0.04$ & $3.7 \pm 0.8$ \\
\hline$\Sigma-\mathrm{PBDE}^{\mathrm{a}}$ & $0.32 \pm 0.09$ & $0.31 \pm 0.04$ & $0.05 \pm 0.01$ & $309 \pm 263$ \\
\hline Total- $(\alpha)-\mathrm{HBCD}^{\mathrm{a}}$ & $0.9 \pm 0.3$ & - & - & - \\
\hline$\Sigma-\mathrm{PBB}^{\mathrm{a}}$ & - & - & - & $73 \pm 68$ \\
\hline$\Sigma-\mathrm{OH}-\mathrm{PBDE}^{\mathrm{b}}$ & $1.4 \pm 1.0$ & $4.3 \pm 2.0$ & - & - \\
\hline$\Sigma-\mathrm{MeO}-\mathrm{PBDE}^{\mathrm{b}}$ & $0.5 \pm 0.3$ & $0.02 \pm 0.01$ & - & $9.1 \pm 7.7$ \\
\hline$\Sigma-\mathrm{OH}-\mathrm{PBB}^{\mathrm{b}}$ & $30 \pm 29$ & $0.6 \pm 0.7$ & $20 \pm 13$ & $0.05 \pm 0.07$ \\
\hline
\end{tabular}

${ }^{\mathrm{a}} \mathrm{ng} / \mathrm{g}$ lipid wt, lipid associated

${ }^{\mathrm{b}} \mathrm{ng} / \mathrm{g}$ wet wt, protein associated 
bioaccumulation accounts for the majority of $\mathrm{MeSO}_{2}-\mathrm{PCBs}$ found in the bear rather than through the biotransformation of PCBs. The BAF of $>1$ for all tissues indicates that, similar to PCBs, the rate of elimination was lower that the rate of uptake.

\subsubsection{Chlorinated Metabolites and Phenolics}

The $\mathrm{BAF}$ of 3-MeSO $\mathrm{M}_{2}-p, p^{\prime}-\mathrm{DDE}$, a metabolite from $p, p^{\prime}-\mathrm{DDE}$, in male fat and liver was significantly $(p<0.05)$ higher than in the corresponding female tissues. For both males and females, the highest BAF was found in the liver, which was significantly $(p<0.0002)$ higher relative to the BAF in fat and blood (Table 4.2). The BAF of the 3-MeSO $2-p, p$ 'DDE from ringed seal blubber to polar bear fat and liver in the present study was similar to the $\mathrm{BAF}$ of the 3-MeSO $2-p, p^{\prime}-\mathrm{DDE}$ from Canadian ringed seals to the analogous polar bear tissues (Letcher et al., 1998). Letcher et al. (1998) noted that the 3-MeSO${ }_{2}-p, p$ 'DDE metabolite, even though detected in both species, is not the predominant metabolite of $p, p^{\prime}$-DDE. However, it is unclear what proportion of the $3-\mathrm{MeSO}_{2}-p, p^{\prime}-\mathrm{DDE}$ accumulated from the ringed seals to the bears versus what proportion was formed through the metabolism of $p, p^{\prime}$-DDE in the polar bears. Due to the fact that polar bears have a higher capacity to metabolize $p, p^{\prime}-\mathrm{DDT}$ and $p, p^{\prime}$-DDE, the majority of 3-MeSO${ }_{2}-$ $p, p^{\prime}-\mathrm{DDE}$ was believed to be formed in the polar bears.

The BAF of PCP from ringed seal blubber to polar bear liver was significantly $(p<0.0003)$ higher than in the other polar bear tissues (Table 4.3). The BAF of PCP in the blood and brain were $<1$, which was probably caused by a lower affinity of the PCP to accumulate in these tissues. Low affinity to TTR binding and/or the ability of the BBB 
to hinder PCP from entering the brain are factors that may have cobtributed to these low BAFs. As previously mentioned, the accumulation of $\mathrm{PCP}$ can have two sources: anthropogenic, it was used as a pesticide; and it can also be formed by the metabolism of hexachlorobenzene (HCB). Although there has not been any evidence that marine mammals are capable of metabolizing HCB, several other species (rats, mice and fish) were shown to be able to form PCP (Renner, 1988). It is believed that, despite the fact that HCB was present in the polar bear tissues; the detected PCP was of an anthropogenic source. Metabolism of HCB would otherwise have resulted in several other (phenolic) metabolites, as were seen in rats, mice and fish.

\subsubsection{Brominated Compounds}

Only in the polar bear liver was the BAF for $\Sigma$-PBDE $>1$. The mean BAF of $309 \pm 263$ was significantly $(p<0.0001)$ higher compared to the BAF of other tissues (Table 4.3). The BAF $<1$ in the fat, blood and brain demonstrates that there is an accumulative preference for the liver, which corroborates interpretations made in Chapter 3 regarding the tissue composition, i.e., selective sequestering mechanisms such as protein binding. Analysing the BAF of PBDEs in only fat tissues indicates that the rate of elimination/metabolism is faster than the rate of uptake. Basing the BAF of PBDEs on only the liver, the tissue with a high preference for accumulating these contaminants, is a more accurate estimate of the bioaccumulative potential of PBDEs. Previous studies have showed that BAFs for PBDEs range from $<1$ to $>1$ from ringed seal blubber to polar bear fat (Wolkers et al., 2004; Muir et al., 2006; Sørmo et al., 2006). Sørmo et al. (2006) showed a similar ringed seal (blubber) to polar bear (fat) BAF for $\Sigma$-PBDE in 


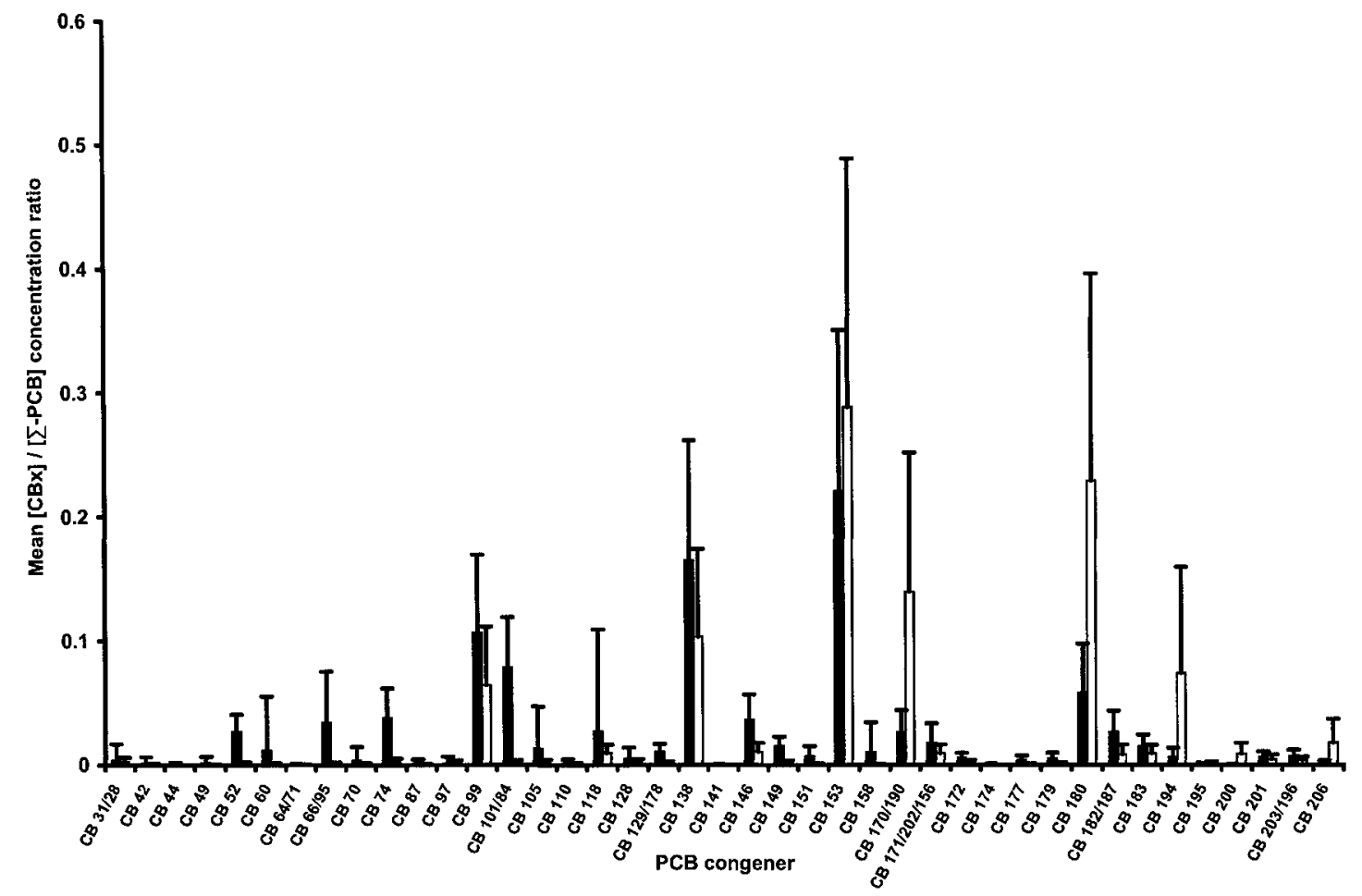

Figure 4.1. Mean ratios of the concentration of PCB congeners to the sum PCB concentrations in ringed seal blubber (black bars) and polar bear fat (white bars). The error bars indicate the \pm SD of the mean ratios. 


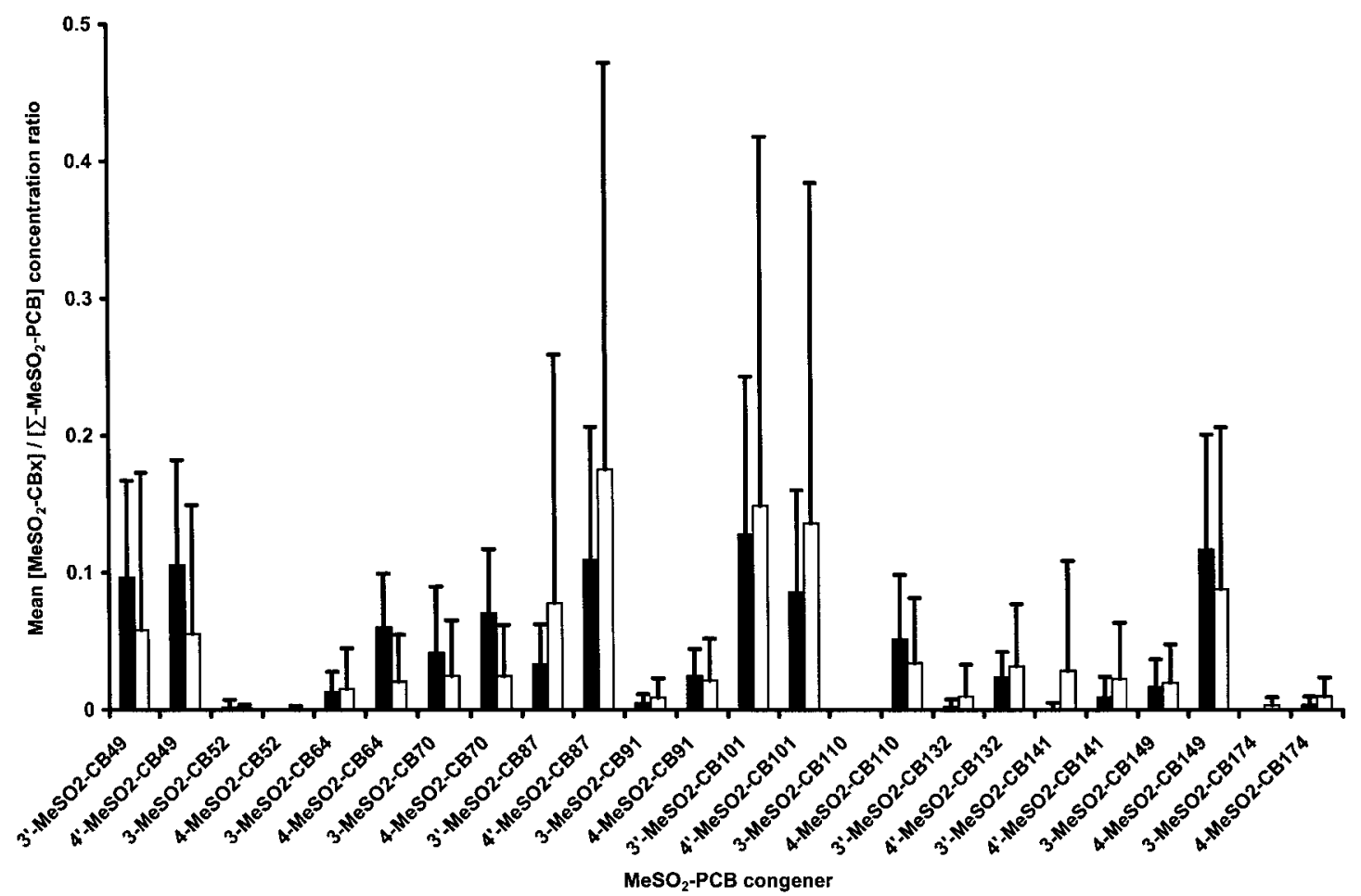

Figure 4.2. Mean ratios of the concentration of $\mathrm{MeSO}_{2}-\mathrm{PCB}$ congeners to the sum $\mathrm{MeSO}_{2}-\mathrm{PCB}$ concentrations in ringed seal blubber (black bars) and polar bear fat (white bars). The error bars indicate the $\pm \mathrm{SD}$ of the mean ratios. 


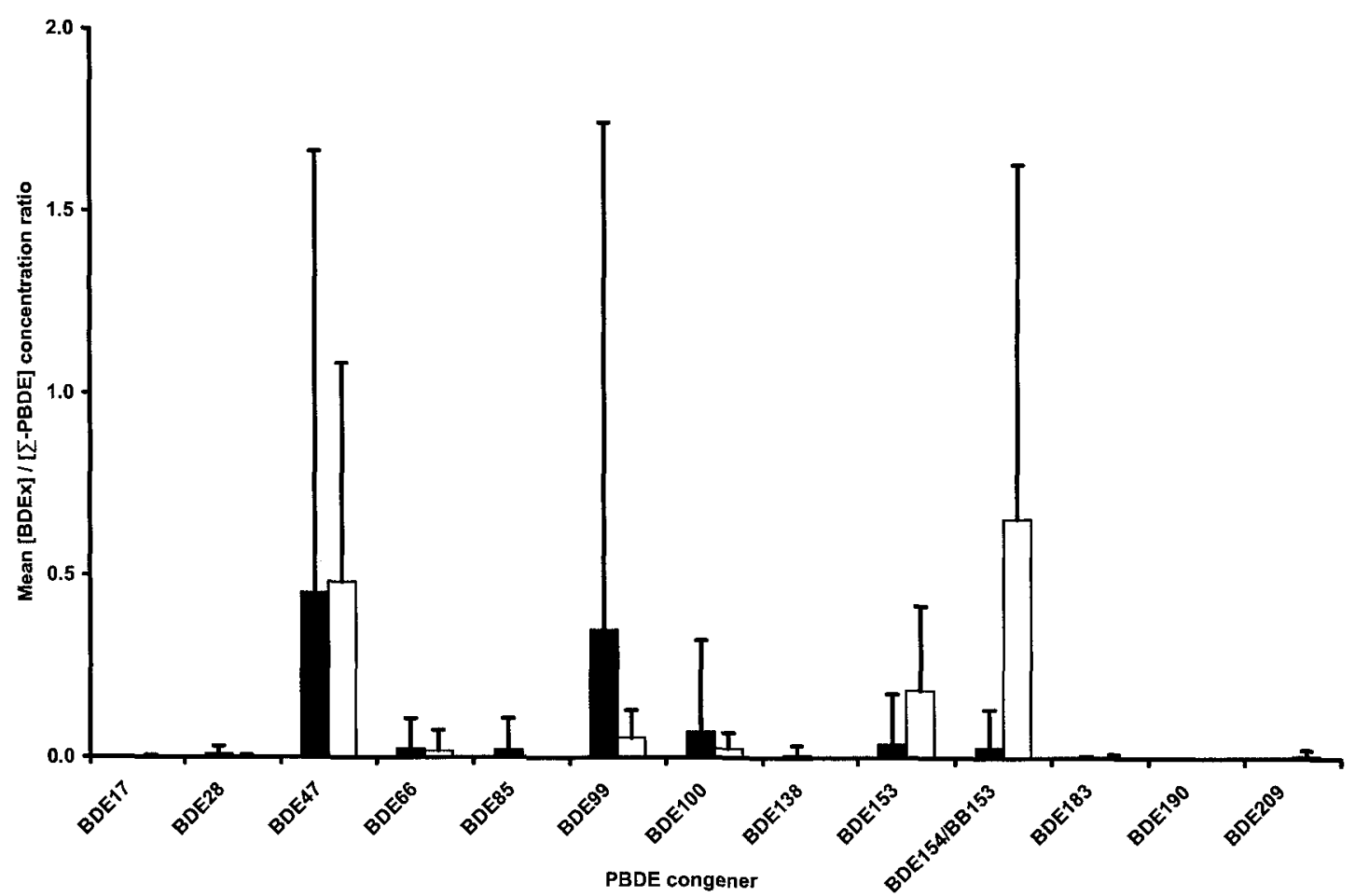

Figure 4.3. Mean ratios of the concentration of PBDE congeners to the sum PBDE concentrations in ringed seal blubber (black bars) and polar bear fat (white bars). The error bars indicate the \pm SD of the mean ratios. 


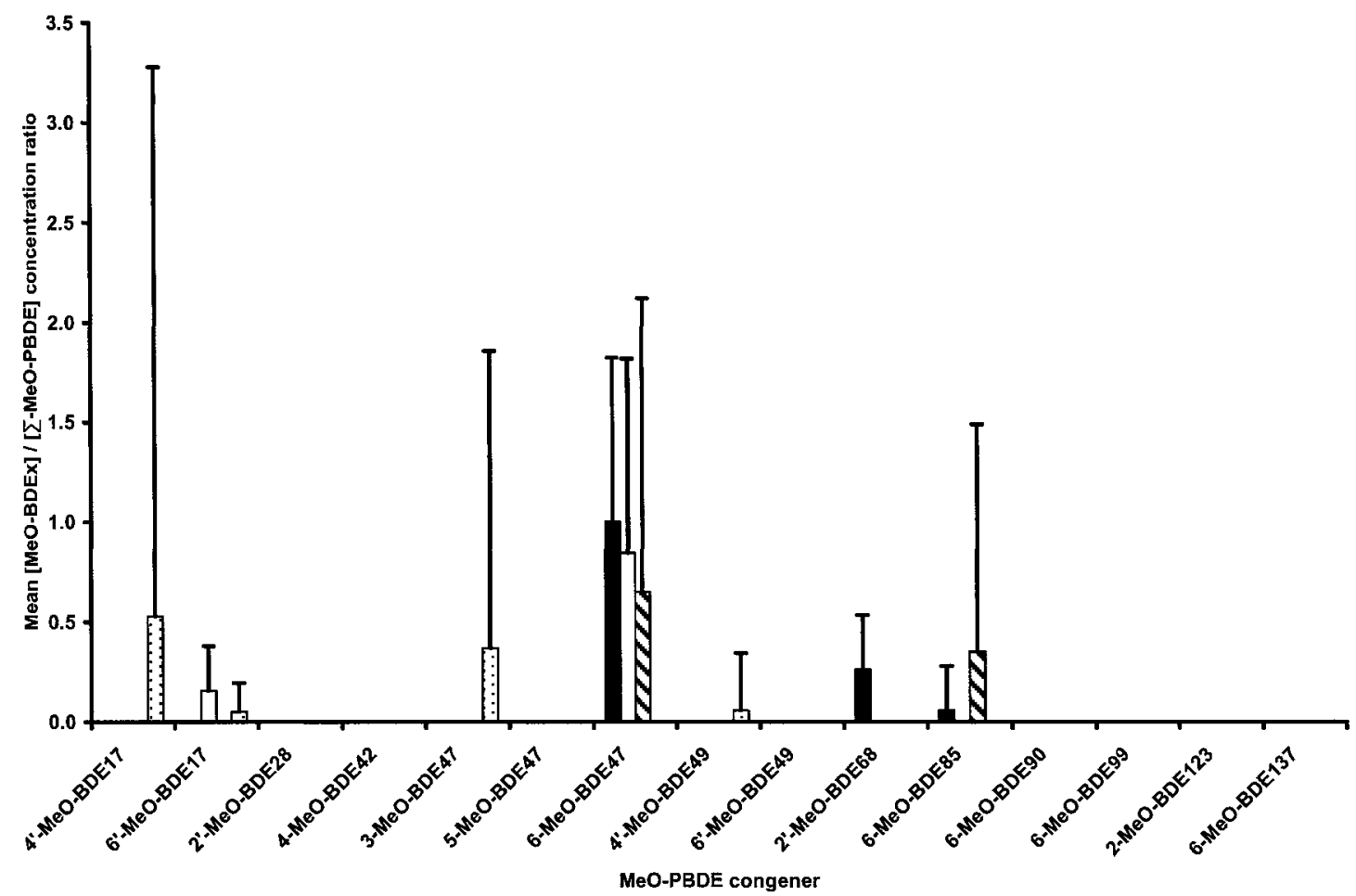

Figure 4.4. Mean ratios of the concentration of MeO-PBDE congeners to the sum MeOPBDE concentrations in ringed seal blubber (black bars), polar bear fat (white bars), blood (stripped bars) and liver (dotted bars). The error bars indicate the \pm SD of the mean ratios. 
Svalbard bears as in the present study, while Wolkers et al. (2004) and Muir et al. (2006) reported BAFs of approximately 2. Using electron impact (EI) ionization was used instead of the more sensitive ECNI, Wolkers et al. (2004) detected only BDE-47 in the polar bear fat, and based the BAF of $\sum$ PBDE only on this congener. The generallly higher BAFs, reported by Muir et al. (2006), may have benn attributed to the fact tha the ringed seal tissues used were collected in different years from the polar bears. No significant difference was seen in the PBDE pattern for the polar bear tissues and ringed seal blubber. The dominant congeners, BDE-47, $-99,-100,-153$ and -154 , were found in all tissues (Figure 4.3). The similar PBDE congener pattern in ringed seals and polar bears suggests that the polar bears' capacity to metabolize/degrade PBDEs was comparable to that of the ringed seals.

OH-PBDEs only accumulated in the fat and blood, with mean BAFs of $1.4 \pm 1.0$ and 4.3 \pm 2.0 , respectively (Table 4.3), indicating biomagnification from seals to polar bears. This is, to our knowledge, the first report on bioaccumulation of OH-PBDEs from ringed seal to polar bear, or in any marine vertebrate andor food chain. Whether the $\mathrm{OH}-$ PBDEs found in the polar bear tissues were formed metabolically or bioaccumulated from the seal blubber is unclear. The 6-OH-BDE47, the only OH-PBDE congener found in ringed seal blubber, was mainly found in the polar bear fat. It was identified as a natural compound that is produced by marine sponges (Carté et al., 1981), and found to have bioaccumulative properties since it was found in species high up in the marine food chain (Marsh et al., 2004). The 3-OH-BDE47, found in polar bear blood, appears to be an oxidative metabolite from BDE-47. During a 90 minutes in vitro microsomal assay, 
no depletion of BDE-47 nor subsequent metabolite formation in situ was observed (Figure 4.5.). Significant depletion $(p<0.01)$ was observed for BDE-15 and BDE-154, demonstrating that oxidative metabolism occurs for these BDE congeners. For several other PBDE congeners, no significant depletion was observed as the rate was too slow. Despite the depletion of the two congeners, no phenolic metabolites were detected. Rat studies have demonstrated that oxidative metabolites of PBDE congeners prelevant in the enviroment, such as 3-OH-BDE47, were formed metabolically after dietary exposure of PBDEs (Hakk et al., 2002, 2006; Mörck et al., 2003; Marsh et al., 2006; Sanders et al., 2006).

The BAFs for MeO-PBDEs (mean BAF $=9.1 \pm 7.7)$ indicate that they bioaccumulate and biomagnify from ringed seal blubber to polar bear liver. However, similar to PBDEs, this apparent biomagnification is liver-specific (Table 4.3). The BAFs for the polar bear fat and blood the BAFs were $<1$. Sources of the MeO-PBDEs are through the food chain bioaccumulation or methylated metabolite formation of OH-PBDEs. Two of the six MeO-PBDEs that were detected in the polar bear tissues were also found in the seal blubber; in this case, the most likely source could be through bioaccumulation (Figure 4.4). The other four congeners were all found in the polar bear liver; in this case, metabolically formed methylated metabolites of OH-PBDEs could likely be the source. Similar to OH-PBDEs, it is unclear if MeO-PBDE congeners are natural products or whether they were formed metabolically. Several MeO-PBDE congeners have been identified as natural products which were produced by algae or sponges (Fu et al., 1995; Handayani et al., 1997; Faulkner, 2002; Malmvärn et al., 2005; Teuten et al., 2005). 
Identified natural products were 6-MeO-BDE47 and 2'-MeO-BDE68. These congeners have been detected in several fish species and marine mammals (Kierkegaard et al., 2004; Marsh et al., 2004; Teuten et al., 2005; McKinney et al., 2006). The OH-PBDE and MeO-PBDEs identified as natural products were ortho substituted, whereas metabolites are usually meta or para hydroxy and methoxy substituted.

The in vivo formation of oxidative metabolites of PBDEs in polar bears plays a smaller role than that of oxidative metabolites of PCBs, as observed by the metabolite-precursor ratio (Table 3.3). This trend was also seen in Norwegian polar bears and several fish species (Valters et al., 2005; Verreault et al., 2005b). The polar bears' ability of metabolizing chlorinated POPs, such as PCBs and OCS, has been proven by the fact that $\mathrm{OH}-\mathrm{PCBs}$ and 4-OH-HpCS were all formed metabolically and did not accumulate from the ringed seal. Polar bears appear to have a lower capacity towards biotransformation of brominated POPs compared to chlorinated POPs. Several of the OH-PBDE and MeOPBDE congeners that were detected in the polar bear tissues could have accumulated through the food chain. Results from an in vitro assay using polar bear hepatic microsomes, which were optimized for cytochrome P450 monoxygenase catalytic activity (Letcher et al., 1996), suggested that polar bears have a low capacity of metabolizing PBDEs. These hepatic microsomes were catalytically active in terms of cytochrome P450 monoxygenases. Re-analysis of the EROD activity of the polar bear 


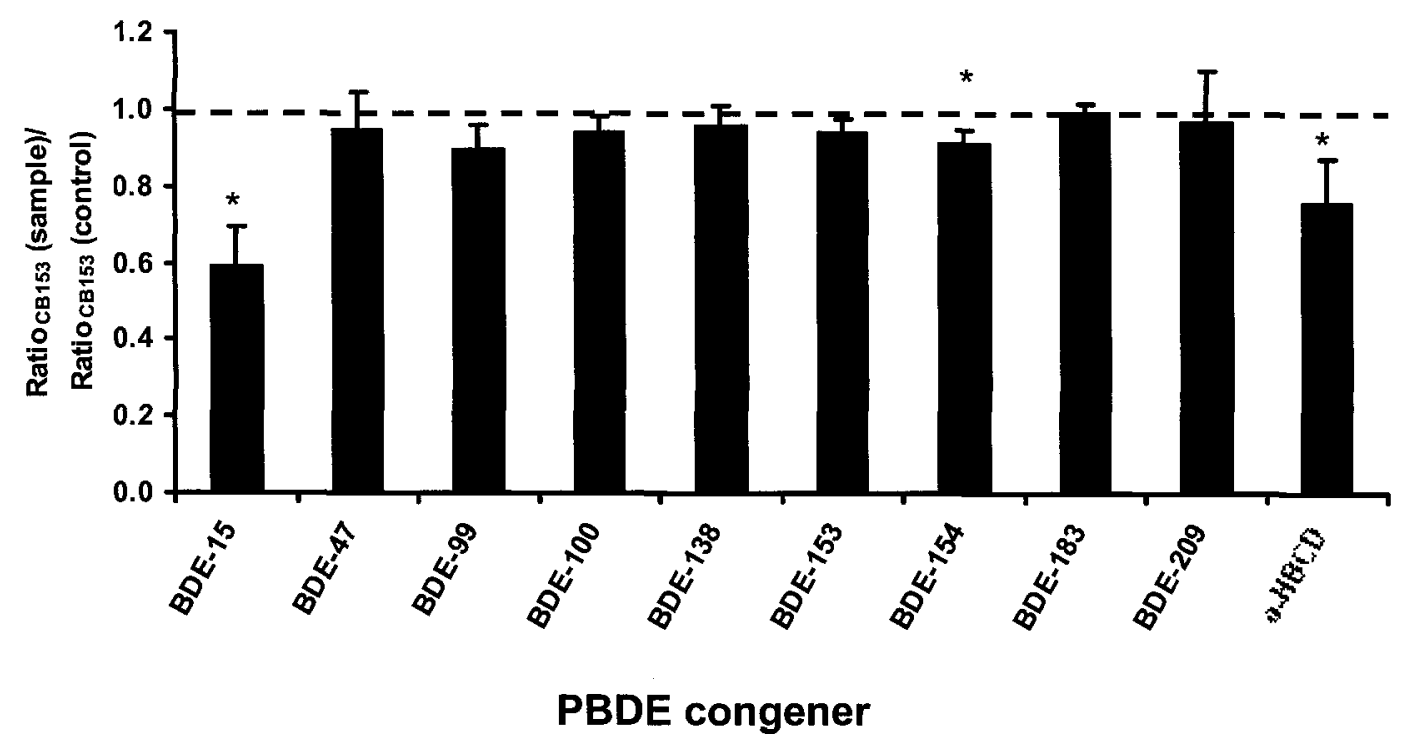

Figure 4.5. Fraction of the BDE congener concentration remaining after a 90 min in vitro assay using hepatic microsomes from polar bear. The dotted lines signify no depletion. Significant depletion $(\mathrm{p}<0.05)$ is marked by an asterisk. Error bars represent \pm SD for replicate assays $(\mathrm{n}=3)$. 
microsomes prepared in 1996 (Letcher et al., 1996) showed that the catalytic activity had dropped $40 \%$ from $1056 \mathrm{pmol} \cdot \mathrm{min}^{-1} \cdot \mathrm{mg}^{-1}$ to $626 \mathrm{pmol} \cdot \mathrm{min}^{-1} \cdot \mathrm{mg}^{-1}$. The positive control, BDE-15 was significantly $(p<0.00006)$ depleted by $41 \%$ during the assay. Of the environmental prelevant PBDE congeners, only BDE-154 significantly $(p<0.01)$ depleted by $9 \%$ (Figure 4.4 ). For both congeners no phenolic metabolites were detected; the MLOQ was approximately $0.05 \mathrm{ng} / \mathrm{g} w \mathrm{w}$.

The BAF for total-( $\alpha)-\mathrm{HBCD}$, which only accumulated in the polar bear fat, was found to be $0.9 \pm 0.3$, demonstrating that total- $(\alpha)$-HBCD bioaccumulates but does not biomagnify in bears. A recent study by Sørmo et al. (2006) on the bioaccumulation of total- $(\alpha)$ HBCD in the Svalbard polar bear food chain showed a comparable BAF from ringed seal blubber to polar bear fat. The BAF of total-( $\alpha)-\mathrm{HBCD}$ found by Sørmo et al. (2006) and also in this study were found to be $<1$, indicating the depletion (i.e., metabolism and/or elimination) of total-( $\alpha$-HBCD in the polar bear. Results from an in vitro assay using polar bear hepatic microsomes showed a significant $(\mathrm{p}<0.02)$ depletion of $24 \%$ for $\alpha$ HBCD (Figure 4.5.). Although oxidative metabolites were not detected, the assay indicated that polar bears were capable of oxidatively metabolizing $\alpha-\mathrm{HBCD}$. Rats exposed to the HBCD technical mixture were observed to have a significant induction of the 7-pentoxyresorufin-O-depentylase (PROD) (i.e., CYP2B) activity (Germer et al., 2006). This metabolic pathway via CYP2B enzymes could have also occurred for the depletion of $\alpha$-HBCD in polar bears (Letcher et al., 1996). 


\subsubsection{PBBs and possible OH-PBB metabolites}

A high mean BAF of $73 \pm 68$ indicated that BB-101 bioaccumulated and biomagnified from ringed seal blubber to only polar bear liver. Similar to other brominated compounds (e.g. PBDEs), selective biomagnification in the liver occured for BB-101, which may be attributed to lipid association and protein binding. To our knowledge, this is the first report on the bioaccumulation of PBBs in the polar bear food chain.

Even though BB-101 biomagnified in the liver, the three OH-PBB congeners were found to bioaccumulate from the ringed seal blubber to all the polar bear tissues. Mean BAFs $>>1$ were found in the fat and brain, while BAFs $<1$ were found in the liver and blood (i.e., tissues with a lower lipid content). Although the highest BAFs were found in lipid rich tissues, there was no correlation between the percent lipid and the OH-PBB level in all the tissues. Biotransformation of PBB precursors may be a source for OH-PBBs in both ringed seals and polar bears. OH-PBBs have been found to be formed metabolically in dogs, rabbits and rats after dietary exposure of mono-brominated-PBB and hexabrominated-PBBs (Kohli et al., 1978; Gardner et al., 1979; Koss et al., 1994). In these studies, besides direct insertion of an OH-group, debromination followed by hydroxylation was also reported resulting in lower brominated $\mathrm{OH}-\mathrm{PBB}$ metabolites. Debromination of BB-101 (i.e., penta-brominated) and subsequent hydroxylation by the polar bear may have resulted in the observed tri- and tetra-brominated OH-PBBs. Since BB-101 is highly bioaccumulative in the liver (BAF of 73), the rate of PBB metabolism appears to be lower than the rate of $\mathrm{PBB}$ uptake in the liver. Besides being formed metabolically, a di-hydroxylated PBB, 2,2'-diOH-BB80, was identified as a natural 
product produced by the Pseudoalteromonas phenolica sponge (Isnansetyo et al., 2003). As observed with the $2,2^{\prime}-\mathrm{diOH}-\mathrm{BB} 80$ and the OH-PBDEs of natural origin, the substitution of the hydroxyl-group is on the ortho position. In this position, the hydroxylgroup seems to favour the accumulation of $\mathrm{OH}-\mathrm{PBBs}$ in lipid rich tissues. OH-PBDEs of natural origin have also been found to accumulate high up in the marine food chain (Marsh et al., 2004).

The fact that higher concentrations of OH-PBBs were found in the polar bear fat and lower in the blood could be an indication that the position and/or degree of $\mathrm{OH}-$ and $\mathrm{Br}$ substitution on the biphenyl rings are not advantageous as they were not for the $\mathrm{OH}$ PCBs with respect to competitive binding affinity with TTR. Expanding on the OH-PBB versus $\mathrm{OH}-\mathrm{PCB}$ comparison, apart from differing in metabolic and accumulated sources, bromine versus chlorine substitution of the hydroxylated biphenyl molecular backbone appears to have a substantial influence on the lipophilicity, retentive protein affinity and/or the biological half-life in bears and seals.

\subsubsection{Comparisons and contrasts with "legacy" organochlorine POPs}

The bioaccumulation of two dominant pesticide classes found in ringed seal and polar bear tissues, $\Sigma$-CHL and $\Sigma$-DDT, takes place mainly in the liver of the polar bear, with BAFs of $184 \pm 41$ and $4.1 \pm 1.5$ for $\Sigma$-CHL and $\Sigma$-DDT, respectively (Table 4.3). BAFs for these two pesticides from seal blubber to bear fat were comparable to earlier studies on various polar bear populations (Muir et al., 1988; Kucklick et al., 2002) 
Comparing the BAFs of the legacy POPs, such as PCBs, chlordanes and DDTs, to the emerging POPs, such as brominated flame retardants and metabolites and/or degradation products; there is an overall trend towards preferential accumulation in the liver. For all POPs, with the exception of OH-PBBs, the BAFs were $>1$ in the liver, indicating biomagnification. Even for parent compounds, such as PCBs, which were clearly metabolized to $\mathrm{MeSO}_{2-}$ and $\mathrm{OH}$-containing POPs, the BAF was far beyond 1. The emerging brominated and phenolic POPs generally had BAFs around or below 1 for the fat and blood; this is in contrast to the legacy chlorinated POPs which generally had BAFs far above one for the fat and blood. The BAF of all contaminants from ringed seal blubber to polar bear brain, with the exception of $\mathrm{OH}-\mathrm{PBBs}$, were all around or below 1 . An explanation could be that the BBB may prevent $\sum$-level of the POPs from entering the brain, resulting in a $\mathrm{BAF}<1$.

\subsubsection{Conclusion and implications}

As seen in the literature, legacy as well as emerging POPs bioaccumulate and in some cases biomagnify, from ringed seal blubber to polar bear tissues (Muir et al., 1988, 2006; Letcher et al., 1998; Wiberg et al., 2000; Sørmo et al., 2006). Especially in the liver, where the highest BAFs were found, biomagnification was seen for all contaminants with the exception of OH-PBBs. BAFs $>1$ indicate that the rate of uptake of the contaminants through diet is faster than the rate of elimination/metabolism. The biomagnification of contaminants from the seal blubber to the polar bear liver corresponds to the high concentrations found in the liver. As discussed in Chapter 3, the possible binding of the POPs to liver proteins, such as the FABP, contributed to the highest concentrations 
amongst the tissues being in the liver. Biomagnification was observed for mostly all chlorinated contaminants in the polar bear fat and blood; while the BAF was $<1$ for most brominated contaminants. BAFs $<1$ indicate that the rate of elimination/metabolism of contaminants is higher than the rate of uptake. This was observed in the brain, where the BAFs of the contaminants were almost all $<1$. The hindering of contaminants from entering the brain by the BBB may have resulted in reduced contaminant levels in the brain.

Several metabolites, such as $\mathrm{MeSO}_{2}-\mathrm{PCBs}, 3-\mathrm{MeSO}_{2}-p, p^{\prime}-\mathrm{DDE}, \mathrm{OH}-\mathrm{PBDEs}, \mathrm{MeO}-$ PBDEs and $\mathrm{OH}-\mathrm{PBBs}$, had BAFs $>1$ in at least one of the polar bear tissues. Letcher et al. (1998) concluded that the main source of $\mathrm{MeSO}_{2}-\mathrm{PCBs}$ in polar bears from the Canadian Arctic was through the bioaccumulation of seal blubber to polar bear fat, and biotransformation of PCBs in the bears was a minor source; only seven of the twenty four identified $\mathrm{MeSO}_{2}$-PCB congeners showed clear indications of being partly formed in the bears. $\mathrm{OH}-$ and MeO-PBDEs and $\mathrm{OH}-\mathrm{PBBs}$ have been identified as natural products and are known to bioaccumulate in the marine food chain (Carté and Faulkner, 1981; Isnansetyo and Kamei, 2003; Malmvärn et al., 2005; Teuten et al., 2005). Bioaccumulation of these contaminants in the polar bear food chain, and the possible formation of these compounds through oxidative metabolism by the bears are pathways for accumulation in the bears' tissues. Brominated phenolic compounds in the seal blubber is a source for bioaccumulation in the polar bears, whereas chlorinated phenolic compounds (metabolites) are not a source; $\mathrm{OH}-\mathrm{PCBs}$ and 4-OH-HpCS were not detected in the seal blubber. 
In previous studies, BAFs were almost entirely based on the accumulation of contaminants from seal blubber to bear fat (Muir et al., 1988, 2006; Letcher et al., 1998; Wiberg et al., 2000; Kucklick et al., 2002). Basing the BAFs of chlorinated, legacy contaminants on fat showed biomagnification of the contaminants from seal to polar bear. The BAFs in the polar bear fat are an underestimation of the rate of bioaccumulation of these chlorinated, legacy contaminants since the BAFs based on the liver are $>>1$. The BAFs of brominated, emerging contaminants in fat indicated that the rate of elimination/metabolism is higher than the rate of uptake; however, it also indicated that there is a localization and biomagnification of these compounds in other tissues (i.e., liver and blood). Aside from the highest contaminant levels being present in the liver, levels of legacy contaminants in the fat were higher relative to the levels in the seal blubber, while levels of most emerging contaminants were lower relative to the seal blubber. Specifically for emerging POPs, the highest biomagnification factors were found in the liver. Basing the BAF of all the POPs entirely on polar bear fat may not be an accurate indicator of the bioaccumulation of emerging contaminants from ringed seal to polar bear bear, as was used in previous studies, since the BAF may be an underestimate of the bioaccumulation of contaminants in the polar bear. 


\section{References}

Braune, B.M., Outridge, P.M., Fisk, A.T., Muir, D.C.G., Helm, P.A., Hobbs, K., Hoekstra, P.F., Kuzyk, Z.A., Kwan, M., Letcher, R.J., Lockhart, W.L., Norstrom, R.J., Stern, G.A., and Stirling, I., 2005. Persistent organic pollutants and mercury in marine biota of the Canadian Arctic: an overview of spatial and temporal trends. The Science of the Total Environment 351-352, 4-56.

Carté, B. and Faulkner, D.J., 1981. Polybrominated diphenyl ethers from Dysodea herbacea, Dysidea chlorea and Phyllospongia foliascens. Tetrahedron 37, 2335 2339.

Derocher, A.E., Andriashek, D. and Stirling, I., 1993. Terrestrial foraging by polar bears during the ice-free period in western Hudson Bay. Arctic 46, 251-254.

Derocher, A.E., Wiig, Ø. and Bangjord, G., 2000. Predation of Svalbard reindeer by polar bears. Polar Biology 23, 675-678.

Faulkner, D.J., 2002. Marine natural products. Natural Product Reports 19, 1-48.

Fu, X., Schmitz, F.J., Govindan, M., Abbas, S.A., Hanson, K.M., Horton, P.A., Crews, P., Laney, M., and Schatzman, R.C., 1995. Enzyme inhibitors: new and known polybrominated phenols and diphenyl ethers from four indo-pacific Dysedea sponges. Journal of Natural Products 58, 1384-1391.

Fu, X. and Schmitz, F.J., 1996. New brominated diphenyl ether from an unidentified species of Dysidea sponge. ${ }^{13} \mathrm{C}$ NMR data for some brominated diphenyl ethers. Journal of Natural Products 59, 1102-1103.

Gardner, A.M., Warren, V.L., Chen, J.-Y.T., and Mazzola, E.P., 1979. A metabolite of polybrominated biphenyls: its identification and decomposition to a brominated dibenzofuran in the gas chromatograph-mass spectrometer. Journal of Agricultural and Food Chemistry 27, 116-119.

Germer, S., Piersma, A.H., Van der Ven, L., Kamyschnikow, A., Frey, Y., Schmitz, H.J., and Schrenk, D., 2006. Subacute effects of the brominated flame retardants hexabromocyclododecane and tetrabromobisphenol A on hepatic cytochrome P450 levels in rats. Toxicology 218, 229-236.

Haglund, P.S., Zook, D.R., Buser, H.-R. and Hu, J., 1997. Identification and quantitation of polybrominated diphenyl ethers and methoxy-polybrominated diphenyl ethers in Baltic biota. Environmental Science and Technology 31, 3281-3287.

Hakk, H., Larsen, G., and Klasson-Wehler, E., 2002. Tissue distribution, excretion and metabolism of 2,2',4,4',5-pentabromodiphenyl ether (BDE-99) in male SpragueDawley rat. Xenobiotica 32, 369-382. 
Hakk, H., Huwe, J.K., Low, M., Rutherford, D., and Larsen,G., 2006. Tissue distribution, excretion and metabolism of 2,2',4,4',6-pentabromodiphenyl ether (BDE-100) in male Sprague-Dawley rats. Xenobiotica 36, 79-94.

Handayani, D., Edrada, R.A., Proksch, P., Wray, V., Witte, L., Van Soest, R.W.M., Kunzmann, A., and Soedarsono, 1997. Four new bioactive polybrominated diphenyl ethers of the sponge Dysidea herbacea from west Sumatra, Indonesia. Journal of Natural Products 60, 1313-1316.

Ikonomou, M.G., Rayne, S., and Addison, R., 2000. Exponential increases of the brominated flame retardants, polybrominated diphenyl ethers, in the Canadian Arctic from 1981 to 2000. Environmetal Science and Technology 36, 1886-1892.

Isnansetyo, A. and Kamei, Y., 2003. MC21-A, a bactericidal antibiotic produced by a new marine bacterium, Pseodoalteromonas phenolica sp. nov. $\mathrm{O}-\mathrm{BC} 30^{\mathrm{T}}$, against methicillin-resistant Staphylococcus aureus. Antimicrobial Agents and Chemotherapy 47, 480-488.

Iverson, S.J., Stirling, I. and Lang, S.L.C., 2006. Spatial and temporal variation in the diets of polar bears across the Canadian Arctic: Indicators of changes in prey populations and environment. Symposia of the Zoological Society of London. In press.

Kierkegaard, A., Bignert, A., Sellström, U., Olssen, M., Asplund, L., Jansson, B., and De Wit, C.A., 2004. Polybrominated diphenyl ethers (PBDEs) and their methoxylated derivatives in pike from Swedish waters with emphasis on temporal trends, 19672000. Environmental Pollution 130, 187-198.

Kohli, J., Wyndham, C., Smylie, M., and Safe, S., 1978. Metabolism of bromobiphenyls. Biochemical Pharmacology 27, 1245-1249.

Koss, G., Weider, T., Seubert, S., and Seubert, A., $1994 . \quad 2,2^{\prime}, 4,44^{\prime}, 5,5^{\prime}-$ hexabromobiphenyl: its toxicokinetics, biotransformation and porphyrinogenic action in rats. Food and Chemical Toxicology 32, 605-610.

Kucklick, J.R., Struntz, W.D.J., Becker, P.R., York, G.W., O'Hara, T.M., and Bohonowych, J.E., 2002. Persistent organochlorine pollutants in ringed seals and polar bears collected from northern Alaska. The Science of the Total Environment 287, 45-59.

Letcher, R.J., Norstrom, R.J., Lin, S., Ramsay, M.A., and Bandiera, S.M., 1996. Immunoquantitation and microsomal monooxygenase activities of hepatic cytochromes P4501A and chlorinated hydrocarbon contaminant levels in Polar bear (Ursus maritimus). Toxicology and Applied Pharmacology 137, 127-140.

Letcher, R.J., Norstrom, R.J., and Muir, D.C.G., 1998. Biotransformation versus bioaccumulation: sources of methyl sulfone PCB and 4,4'-DDE metabolites in the polar bear food chain. Environmetal Science and Technology 32, 1656-1661. 
Malmberg, T., Cenijn, P. H., Gutleb, A. C., and Bergman, A., 2004. Methanol-water dissociation constants and relative transthyretin affinities for hydroxylated metabolites of PCB and PBDE congeners. Stockholm University, Stockholm, Sweden.

Malmvärn, A., Marsh, G., Kautsky, L., Athanasiadou, M., Bergman, A., and Asplund, L., 2005. Hydroxylated and methoxylated brominated diphenyl ethers in the Red Algae Ceramium tenuicorne and Blue Mussels from the Baltic Sea. Environmental Science and Technology 39, 2990-2997.

Marsh, G., Athanasiadou, M., Bergman, Å., and Asplund, L., 2004. Identifivation of hydroxylated and methoxylated polybrominated diphenyl ethers in Baltic Sea salmon (Salmo salar) blood. Environmental Science and Technology 38, 10-18.

Marsh, G., Athanasiadou, M., Athanassiadis, I., Bergman, A., Endo, T., and Haraguchi, K., 2005. Identification, quantification, and synthesis of a novel dimethoxylated polybrominated biphenyl in marine mammals caught of the coast of Japan. Environmental Science and Technology

Marsh, G., Athanasiadou, M., Athanassiadis, I., and Sandholm, A., 2006. Identification of hydroxylated metabolites in $2,2^{\prime}, 4,4^{\prime}$-tetrabromodiphenyl ether exposed rats. Chemosphere 63, 690-697.

McKinney, M.A., De Guise, S., Martineau, D., Beland, P., Lebeuf, M., and Letcher, R.J., 2006. Organohalogen contaminants and metabolites in beluga whale (Delphinapterus leucas) liver from two canadian populations. Environmental Toxicology and Chemistry 25, 1246-1257.

Mörck, A., Hakk, H., Örn, U., and Klasson-Wehler, E., 2003. Decabromodiphenyl ether in the rat: absorption, distribution, metabolism, and excretion. Drug Metabolism and Disposition 31, 900-907.

Muir, D.C.G., Norstrom, R.J., and Simon, M., 1988. Organochlorine contaminants in arctic marine food chains: accumulation of specific polychlorinated biphenyls and chlordane-related compounds. Environmental Science and Technology 22, 1071 1079 .

Muir, D.C.G., Backus, S.M., Derocher, A.E., Dietz, R., Evans, T., Gabrielsen, G.W., Nagy, J., Norstrom, R.J., Sonne, C., Stirling, I., Taylor, M.K., and Letcher, R.J., 2006. Brominated flame retardants in polar bears (Ursus maritimus) from Alaska, the Canadian Arctic, Greenland, and Svalbard. Environmental Science and Technology 40, 449-455.

Norstrom, R.J., Belikov, S.E., Born, E.W., Garner, G.W., Malone, B., Olpinski, S., Ramsay, M.A., Schliebe, S., Stirling, I., Stishov, M.S., Taylor, M.K., and Wiig, O.,1 998. Chlorinated hydrocarbon contaminants in polar bears from Eastern Russia, North America, Greenland, and Svalbard: biomonitoring of Artic pollution. Archives Of Environmetal Contamination and Toxicology 35, 354-367. 
Renner, G., 1988. Hexachlorobenzene and its metabolism. Toxicological and Environmental Chemistry 18, 51-78.

Sandala, G.M., Sonne-Hansen, C., Dietz, R. Muir, D.C.G., Valters, K., Bennett, E.R., Born, E.W., Letcher, R.J., 2004. Hydroxylated and methyl sulfone PCB metabolites in adipose and whole blood of polar bears (Ursus maritimus) from East Greenland. The Science of the Total Environment 331, 125-141.

Sandau, C.D., Meerts, I.A.T.M., Letcher, R.J., McAlees, A.J., Chittim, B., Brouwer, A., and Norstrom, R.J., 2000. Identification of 4-hydroxyheptachlorostyrene in polar bear plasma and its binding affinity to transthyretin: a metabolite of octachlorostyrene. Environmental Science and Technology 34, 3871-3877.

Sanders, J.M., Chen, L.-J., Lebetkin, E.H., and Burka, L.T., 2006. Metabolism and disposition of 2,2',4,4'-tetrabromodiphenyl ether following administration of single or multiple doses to rats and mice. Xenobiotica 36, 103-117.

Smith, T. G., 1980. Polar bear predation of ringed and bearded seals in the land-fast sea ice habitat. Canadian Journal of Zoology 58, 2201-2209.

Smith, T. G. and Sjare, B., 1990. Predation of belugas and narwhals by polar bears in nearshore areas of the Canadian High Arctic. Arctic 43, 99-102.

Sørmo, E.G., Salmer, M.P., Jenssen, B.M., Hop, H., Bæk, K., Kovacs, K.M., Lydersen, C., Falk-Petersen, S., Gabrielsen, G.W., Lie, E., and Skaare, J.U., 2006. Biomagnification of brominated flame retardants in the polar bear food chain in Svalbard, Norway. Environmental Toxicology and Chemistry 25, 2502-2511.

Stirling, I. and Archibald, W.R, 1977. Aspects of predation of seals by polar bears. Journal of the Fisheries Research Board of Canada 34, 126-129.

Teuten, E.L., Xu, L., and Reddy, C.M., 2005. Two abundant bioaccumulated halogenated compounds are natural products. Science 307, 917-920.

Valters, K., Li, H., Alaee, M., D'Sa, I., Marsh, G., Bergman, ̊̊., and Letcher, R.J., 2005. Polybrominated diphenyl ethers and hydroxylated and methoxylated brominated and chlorinated analogues in the plasma of fish from the Detroit River. Environmental Science and Technology 39, 5612-5619.

Verreault, J., Muir, D.C.G., Norstrom, R.J., Stirling, I., Fisk, A.T., Gabrielsen, G.W., Derocher ,A.E., Evans, T.J., Dietz, R., Sonne, C., Sandala, G.M., Gebbink, W.A., Taylor, M.K., Nagy, J., and Letcher, R.J., 2005a. Chlorinated hydrocarbon contaminants and metabolites in polar bear (Ursus maritimus) from Alaska, Canada, East Greenland, and Svalbard: 1996-2002. The Science of the Total Environment 351-352, 369-390. 
Verreault, J., Gabrielsen, G.W., Chu, S., Muir, D.C.G., Andersen, M., Hamaed, A., and Letcher, R.J., 2005b. Flame retardants and methoxylated and hydroxylated polybrominated diphenyl ethers in two Norwegian Arctic top predators: glaucous gulls and polar bears. Environmental Science and Technology 39, 6021-6028.

Vorkamp, K., Christensen, J.H., and Riget, F.F., 2004a. Polybrominated diphenyl ethers and organochlorine compounds in biota from the marine environment of East Greenland. The Science of the Total Environment 331, 143-155.

Vorkamp, K., Riget, F.F., Glasius, M., Pécseli, M., Lebeuf, M., and Muir, D.C.G., 2004b. Chlorobenzenes, chlorinated pesticides, coplanar chlorobiphenyls and other organochlorine compounds in Greenland biota. The Science of the Total Environment 331, 157-175.

Wiberg, K., Letcher, R.J., Sandau, C.D., Norstrom, R.J., Tysklind, M., and Bidleman, T.F., 2000. The enantioselective bioaccumulation of chiral chlordane and $\square-\mathrm{HCH}$ contaminants in the polar bear food chain. Environmental Science and Technology 34, 2668-2674.

Wolkers, H., Van Bavel, B., Derocher, A.E., Wiig, Ø. Kovacs, K.M., Lydersen, C., Lindström, G., 2004. Congener-specific accumulation and food chaion transfer of polybrominated diphenyl ethers in two Arctic food chains. Environmental Science and Technology 38, 1667-1674.

Wolkers, J., Burkow, I.C., Lydersen, C., Dahle, S., Monshouwer, M., Witkamp, R.F., 1998. Congener specific PCB and polychlorinated camphene (toxaphene) levels in Svalbard ringed seals (Phoca hispida) in relation to sex, age, condition and cytochrome P450 enzyme activity. The Science of the Total Environment 216, 111. 


\section{CHAPTER 5}

\section{Conclusions}

The present study examined the predator-prey bioaccummulation and toxicokinetics of several classes of brominated and chlorinated contaminants and analogues, metabolites and/or degradation or natural products in polar bears (Ursus maritimus) and ringed seals (Phoca hispida) from the East Greenland population of the Arctic. Several of the organohalogens under study had yet to be identified in the polar bears or ringed seals (e.g., OH-PBBs). In addition, in instances were these novel organohalogens of environmental relevance had previously been identified in the polar bears or ringed seals, and were shown to be metabolically related (e.g., $\mathrm{PCBs}, \mathrm{MeSO}_{2}-\mathrm{PCBs}$ and $\mathrm{OH}-\mathrm{PCBs}$ ), an inter-species relationship has not been reported until this study with respect to an integrated assessment of contaminants in polar bears or ringed seals. A large focus was on tissue-specific bioaccummulation and toxicokinetics with respect to concentrations and congener patterns.

The following are highlights of some of the more important and specific findings in this thesis. Of the selected tissues, the polar bear liver and blood showed to contain the highest concentrations of neutral and phenolic brominated and chlorinated contaminants and metabolites. In both those tissues, protein association, the binding to the FABP in the liver and TTR in the blood, appears to play a greater role than the accumulation in the lipids. The BBB appears to partially protect to brain from the organohalogens entering the brain. The lowest levels of contaminants amongst the selected tissues and blood were 
found in the brain, regardless reported and wet weight or lipid weight basis. Albeit reducing $\sum$-levels from entering the brain, the BBB showed no capability to retain specific congeners; there was no significant difference in congener patterns in the blood and brain. Tight junctions between the cerebral endothelial cells at the blood-brain interface represent the structural basis of the BBB. There are a variety of different mechanisms by which exogenous compounds can migrate through the BBB, e.g. passive diffusion, transcytosis, receptor-mediated absorptive endocytosis, and/or facilitated/active transport systems.

Comparing the tissue burden of the POPs, the fat contained the majority ( $86 \%)$ of all the contaminants, followed by the liver $(11 \%)$, the blood $(3 \%)$ and the brain $(<0.02 \%)$. The burden of chlorinated neutral contaminants (PCBs, DDTs, chlordanes) was found to be dominated by the fat, while the burden of brominated neutral contaminants (PBDEs and PBBs) was found mainly in the liver. There was a high selectivity towards the accumulation of brominated neutral contaminants in the liver, PBDEs made up $43 \%$ of the contaminant burden in the liver. For brominated and chlorinated phenolic contaminants, the majority of the tissue burden was found in the blood. The brain contained less than $0.02 \%$ of the body burden for all the POPs, the BBB seemed capable in reducing the amount of POPs in the brain relative to other tissues. Although there are structural similarities between PCBs, PBDEs, and PBBs, they behave differently in the polar bears. Whether the POPs were brominated or chlorinated had a big influence on the mechanism of tissue-specific accumulation and toxicokinetics of these contaminants. 
Polar bears are exposed to POPs through their diet, mainly ringed seal blubber. Analysis of ringed seal blubber showed the presence of all the POPs that were found in the polar bear tissues with the exception of chlorinated phenolic compounds. Although ringed seals are capable to metabolize PCBs and OCS (low levels of OH-PCBs and 4-OH-HpCS were detected in seal blood), in the seals blubber, OH-PCBs and 4-OH-HpCS were not detected due to overall low levels and low affinity of these metabolites to accumulate in blubber. With the exception of neutral brominated contaminants in the fat and OH-PBBs in the liver, BAFs of the POP classes from the ringed seal blubber to the bears fat and liver were almost all $>1$ indicating biomagnification of those contaminants in those tissues. In the polar bear blood and brain, the BAFs of several contaminant classes, mainly emerging contaminants, were $<1$; elimination plays a bigger role than biomagnification. In the PCB congener pattern there was a difference observed between ringed seals and polar bear. Lower chlorinated PCBs, which were present in the seals, were metabolized by the polar bears. There was no difference seen in the $\mathrm{MeSO}_{2}-\mathrm{PCB}$ and PBDE congener pattern between the seals and bears, one OH-PBDE and several MeO-PBDE congeners were detected in the polar bear tissues while they were not present in the seals blubber. Oxidative metabolism of PCBs in polar bears takes place at a higher rate compared to the oxidative metabolism of PCBs in ringed seals. In the bears, oxidative metabolism of PBDEs takes place at a slower rate compared to oxidative metabolism of PCBs.

There was a contrast in the levels and origin of halogenated phenolic contaminants in the polar bear tissues. OH-PCBs were all formed by oxidative metabolism of PCBs in the 
polar bear and although detected in all the tissues, accumulated mainly in the blood. OHPBDEs accumulated from the seal blubber $(6-\mathrm{OH}-\mathrm{BDE} 47$ was identified as a natural product), and were formed by oxidative metabolism as well. The accumulation of $\mathrm{OH}-$ PBDEs was only seen in the fat and blood, not in the brain and liver. The three identified OH-PBBs were found predominantly in lipid rich tissues and were thought to be of natural origin. The type of halogenation and the position of the hydroxyl-group (orthosubstituted) play a key role in the accumulation and origin of the halogenated compounds. The ortho hydroxy substituted halohenated phenolics are believed to be of a natural source and are more lipid associated, several ortho-OH-PBDE have been found to bioaccumulate in the marine food chain.

Especially the halogenated phenolic compounds have endocrine disrupting properties; they can disrupt thyroid hormone levels in the blood. In polar bears, legacy POPs were proved to influence the levels of several different hormones polar bears, e.g., thyroid hormones, testosterone, progesterone and retinol. Disruption of those hormone systems could impact the growth and development of the polar bears. Organohalogen exposure to East Greenland polar bears is also linked to the disruption of the bone mineral composition and the development of renal lesions. 
Future Research Directions

There was a clear difference observed in the accumulation of brominated and chlorinated contaminants in the liver relative to the fat. Although POP concentrations in the liver were higher than the fat concentrations in several species, the difference that was observed in this study, up to 2 orders of magnitude higher, has not been seen previously. Aside from the binding of the PCBs to an unknown rat liver protein, and the binding of bis- $\mathrm{MeSO}_{2}$-CB52 and BDE-209 to the liver FABP in rats and chickens (Larsen et al., 1991, 1992; Buff et al., 1992; Bründl et al., 1993; Haraguchi et al., 1997), there is a lack of information on the binding of the POPs to liver proteins in general, and especially in the polar bear liver. Identifying the liver proteins that bind the contaminants gives more information about the mechanism of retention of the contaminants in the liver.

The discovery of OH-PBBs in ringed seal and polar bear tissues raised questions about the identity and origin. As mentioned previously, $\mathrm{OH}-\mathrm{PBBs}$ can be of natural origin, 2,2'-diOH-BB80 has identified as a natural product produced by Pseudoalteromonas phenolica sponge. Oxidative metabolism of PBB could also be a source; in vivo studies have demonstrated that dogs, rabbits and rats were able to form OH-PBB after dietary exposure to PBBs. Besides the information that is present, looking at the relative abundance of the ion isotopic pattern of the three unknown OH-PBBs in different ionization techniques, could give an indication of the position of the OH-group on the biphenyl backbone. Synthesis of possible structures and comparing retention times to the unknowns could ultimately lead to the identification of the unknowns. 


\section{References}

Bründl, A. and Buff, K., 1993. Partial purification and characterization of a rat liver polychlorinated biphenyl (PCB) binding protein. Biochemical Pharmacology 45, 885-891.

Buff, K. and Bründl, A., 1992. Specific binding of polychlorinated biphenyls to rat liver cytosol protein. Biochemical Pharmacology 43, 965-970.

Hakk, H., Larsen, G., Bergman, Å., and Örn, U., 2002. Binding of brominated diphenyl ethers to male rat carrier proteins. Xenobiotica 32, 1079-1091.

Haraguchi, K., Kato, Y., Masuda, Y., and Kimura, R., 1997. Metabolism of 3,3',4,4'tetrachlorobiphenyl via sulphur-containing pathway in rat: liver-specific retention of methylsulphonyl metabolite. Xenobiotica 27, 831-842.

Larsen, G. L., Bergman, A., Klasson-Wehler, E., and Bass, N. M., 1991. A methylsulfonyl metabolite of a polychlorinated biphenyl can serve as a ligand for fatty acid binding protein in rat intestinal mucosa. Chemico-Biological Interactions 77, 315-323.

Larsen, G. L., Huwe, J. K., Bergman, Å., Klasson-Wehler, E., and Hargis, P., 1992. Methylsulfonyl metabolites of xenobiotics can serve as ligands for fatty acid binding proteins in chicken liver and intestinal mucosa. Chemosphere 25, 1189 1194. 
Appendix 1 - Sample information of polar bears collected in 1999-2001 in central East Greenland.

\begin{tabular}{|c|c|c|c|c|c|c|c|c|c|c|}
\hline $\begin{array}{l}\text { Collection } \\
\text { ID No. }\end{array}$ & $\begin{array}{l}\text { Sampling } \\
\text { Date }\end{array}$ & Sex & $\begin{array}{c}\text { Age } \\
\text { (years) }\end{array}$ & $\begin{array}{c}\text { Girth } \\
\text { circum }(\mathrm{cm})\end{array}$ & $\begin{array}{c}\text { Zool. } \\
\text { length }(\mathrm{cm}) \\
\end{array}$ & $\begin{array}{c}\text { Body } \\
\text { Weight }(\mathrm{kg})^{\mathrm{b}} \\
\end{array}$ & $\begin{array}{c}\text { Body } \\
\text { Fat }(\mathrm{kg})^{\mathrm{c}} \\
\end{array}$ & $\begin{array}{c}\text { Weight } \\
\text { Blood }(\mathrm{kg})^{\mathrm{d}} \\
\end{array}$ & $\begin{array}{c}\text { Weight } \\
\text { Brain (kg) } \\
\end{array}$ & $\begin{array}{c}\text { Weight } \\
\text { Liver }(\mathrm{kg})^{\mathrm{f}} \\
\end{array}$ \\
\hline 21680 & 28 August 1999 & F & 22 & 231.5 & 152 & 451 & 226 & 35.8 & 0.118 & 7.8 \\
\hline 21693 & 6 September 1999 & F & 10 & 208 & 148 & 361 & 108 & 28.6 & 0.100 & 6.4 \\
\hline 21695 & 11 May 2000 & F & 16 & 138 & 234 & 329 & 99 & 26.1 & 0.093 & 5.9 \\
\hline 21709 & 9 July 1999 & $\mathrm{~F}$ & 23 & 148.5 & 168.5 & 239 & 119 & 19.0 & 0.073 & 4.4 \\
\hline 21720 & 13 February 2000 & $\mathrm{~F}$ & 12 & 204.5 & 237 & 667 & 133 & 53.0 & 0.159 & 11 \\
\hline 21727 & 24 March 2000 & $\mathrm{~F}$ & 8 & 142 & 200 & 279 & 84 & 22.2 & 0.082 & 5.1 \\
\hline 21748 & 21 March 2000 & $\mathbf{F}$ & 5.5 & 132 & 179.5 & 212 & 64 & 16.8 & 0.067 & 4.0 \\
\hline $21755^{\mathrm{a}}$ & 5 January 2000 & F & 19 & - & - & - & - & - & - & - \\
\hline 21772 & 11 January 2001 & $\mathrm{~F}$ & 20 & 176 & 200 & 406 & 81 & 32.3 & 0.109 & 7.1 \\
\hline 22204 & 8 September 2000 & $F$ & 9.5 & 166 & 156 & 261 & 131 & 20.7 & 0.078 & 4.8 \\
\hline 21705 & 23 June 1999 & $\mathrm{M}$ & 25 & 131 & 241 & 313 & 156 & 24.8 & 0.089 & 5.6 \\
\hline 21711 & 11 August 2000 & $\mathbf{M}$ & 8.5 & 187 & 240 & 580 & 290 & 46.1 & 0.143 & 9.7 \\
\hline 21721 & 30 August 2000 & $\mathrm{M}$ & 6 & 128 & 200 & 233 & 116 & 18.5 & 0.071 & 4.3 \\
\hline 21730 & 24 March 2000 & $\mathrm{M}$ & 15 & 200 & 244 & 667 & 200 & 53.0 & 0.159 & 11 \\
\hline 21736 & 27 August 1999 & $\mathrm{M}$ & 6 & 163.5 & 213.5 & 391 & 195 & 31.0 & 0.106 & 6.8 \\
\hline 21737 & 24 September 1999 & $\mathrm{M}$ & 8.5 & 207 & 228 & 646 & 194 & 51.3 & 0.155 & 11 \\
\hline 21738 & 22 February 2000 & $M$ & 16 & 250 & 224.5 & 880 & 176 & 69.9 & 0.197 & 14 \\
\hline 21763 & 21 March 2000 & $\mathrm{M}$ & 8 & 157 & 219 & 377 & 113 & 29.9 & 0.103 & 6.6 \\
\hline 21770 & 16 September 1999 & $\mathrm{M}$ & 6 & 197 & 212 & 536 & 161 & 42.6 & 0.135 & 9.0 \\
\hline 21771 & 24 January 2001 & $\mathrm{M}$ & 7 & 194 & 226 & 712 & 142 & 56.5 & 0.167 & 12 \\
\hline $\begin{array}{l}{ }^{a} \text { Girth and } \\
{ }^{b} \text { Polar bea } \\
{ }^{c} \text { Body fat } \\
{ }^{d} \text { Blood we } \\
{ }^{e} \text { Brain wei } \\
{ }^{\mathrm{f}} \text { Blood we }\end{array}$ & $\begin{array}{l}\text { ngth of polar bea } \\
\text { ody weight calcu } \\
\text { timated according } \\
\text { ht calculated acco } \\
\text { it calculated accor } \\
\text { ht calculated acco }\end{array}$ & $\begin{array}{l}21755 \\
\text { ted as } \\
o \text { Atk } \\
\text { ling t } \\
\text { ing to } \\
\text { ing to }\end{array}$ & $\begin{array}{l}\text { Nere not } \\
\text { ording } \\
\text { son et a } \\
\text { Prother } \\
\text { Armstro } \\
\text { Prothero }\end{array}$ & $\begin{array}{l}\text { ported } \\
\text { Derocher et } \\
1996 \text { and pe } \\
1980 \\
\text { et al., } 1983 \\
1982\end{array}$ & $\begin{array}{l}1998 \\
\text { onal commu }\end{array}$ & cation with D & A. Deroch & 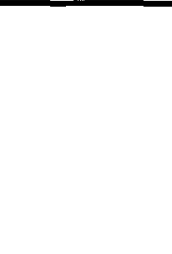 & 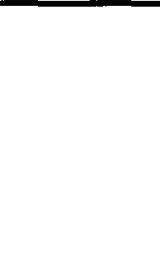 & 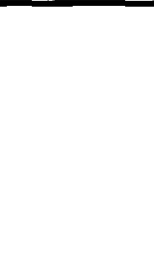 \\
\hline
\end{tabular}


Appendix 2 - Sample information of ringed seals collected in 2002 in central East Greenland.

\begin{tabular}{cccccc}
\hline $\begin{array}{c}\text { Collection } \\
\text { ID No. }\end{array}$ & $\begin{array}{c}\text { Sampling } \\
\text { Date }\end{array}$ & Sex & $\begin{array}{c}\text { Age } \\
\text { (years) }\end{array}$ & $\begin{array}{c}\text { Zool. } \\
\text { length }(\mathrm{cm})\end{array}$ & $\begin{array}{c}\text { Weight } \\
(\mathrm{kg})\end{array}$ \\
\hline & & & & & \\
24931 & 2002 & $\mathrm{~F}$ & 8.5 & 131 & 59 \\
24935 & 2002 & $\mathrm{~F}$ & 6.5 & 117 & 37 \\
24939 & 2002 & $\mathrm{~F}$ & 4.5 & 113 & 43 \\
24940 & 2002 & $\mathrm{~F}$ & 6.5 & 111 & 37 \\
24944 & 2002 & $\mathrm{~F}$ & 11.5 & 146 & 79 \\
24948 & 2002 & $\mathrm{~F}$ & 1.5 & 101 & 28.5 \\
24932 & 2002 & $\mathrm{M}$ & 4.5 & 117 & 45 \\
24933 & 2002 & $\mathrm{M}$ & 4.5 & 111 & 39 \\
24934 & 2002 & $\mathrm{M}$ & 5.5 & 111 & 37 \\
24936 & 2002 & $\mathrm{M}$ & 5.5 & 117 & 43 \\
24937 & 2002 & $\mathrm{M}$ & 3.5 & 112 & 43 \\
24938 & 2002 & $\mathrm{M}$ & 5.5 & 121 & 48 \\
24941 & 2002 & $\mathrm{M}$ & 1.5 & 104 & 27 \\
24943 & 2002 & $\mathrm{M}$ & 7.5 & 106 & 34 \\
24945 & 2002 & $\mathrm{M}$ & 4.5 & 116 & 41 \\
\hline
\end{tabular}


Appendix 3 - GC-MSD (ECNI) full scan mass spectra (50-550 amu) of unknown OH-PBBs.

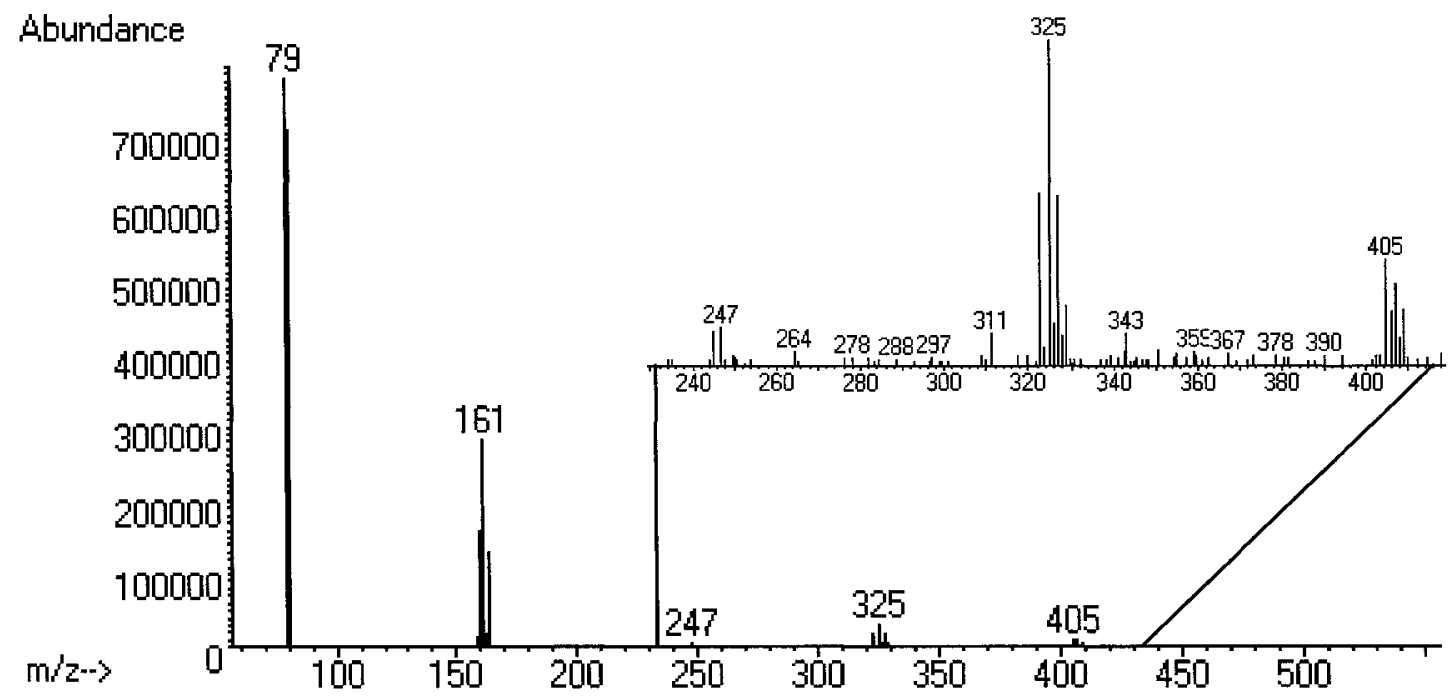

GC-MSD (ECNI) Full scan mass spectrum unknown 1

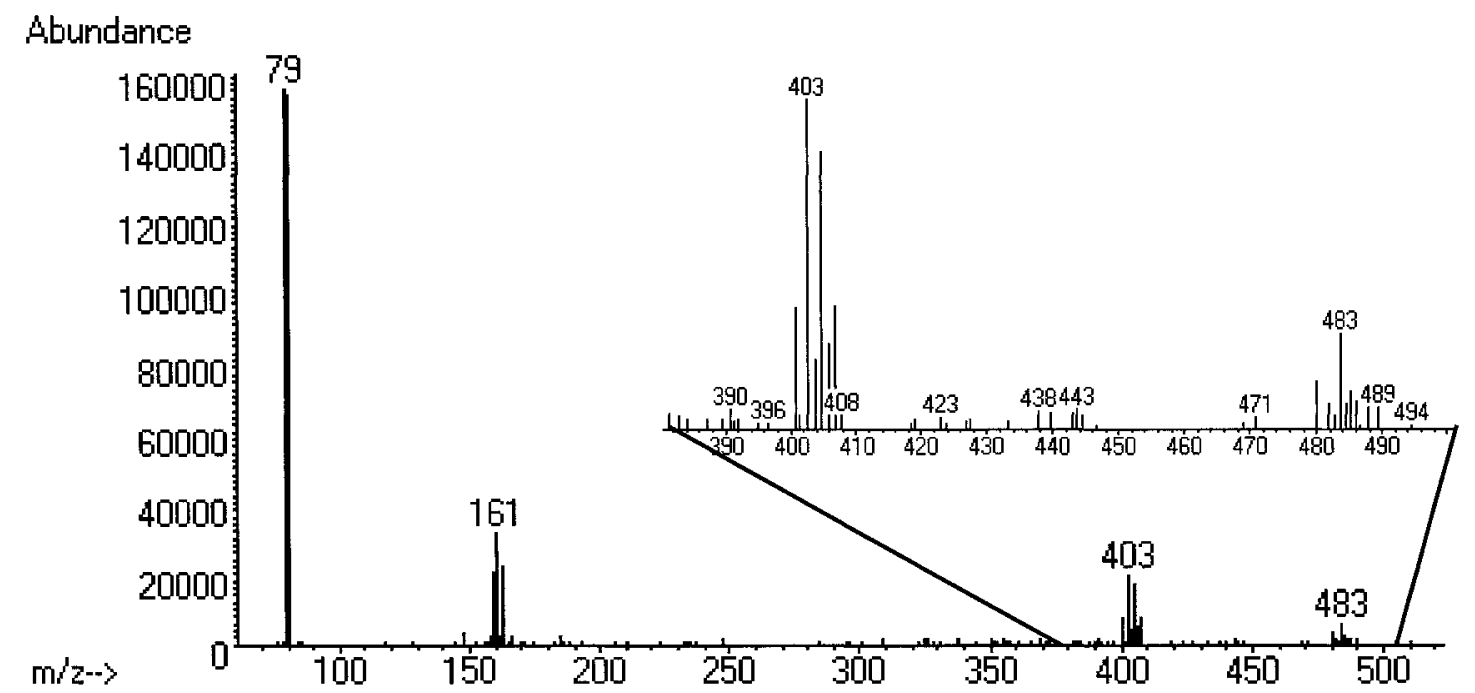

GC-MSD (ECNI) Full scan mass spectrum unknown 2 
Abundance

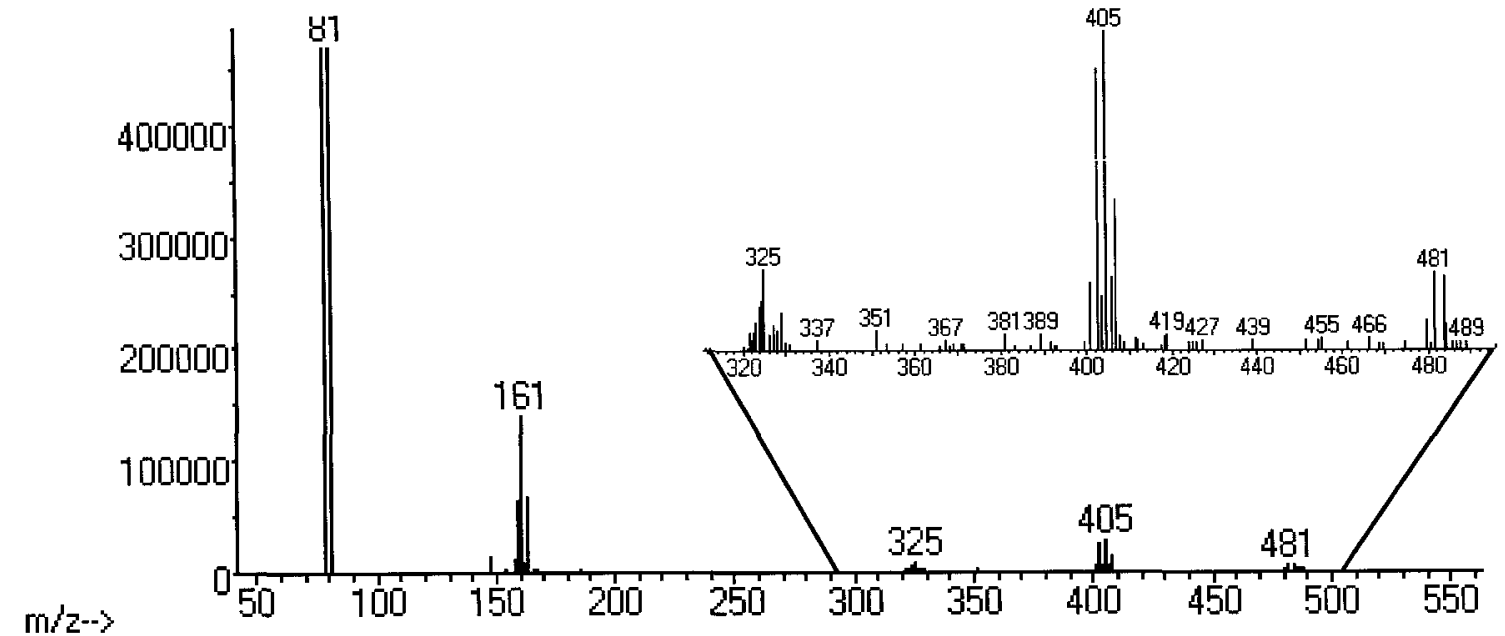

GC-MSD (ECNI) Full scan mass spectrum unknown 3 